\title{
The Early Pliocene extinction of the mega-toothed shark Otodus megalodon: A view from the eastern North Pacific
}

\author{
Robert W Boessenecker ${ }^{\text {Corresp., }}$ 1, 2, 3 ， Dana J Ehret ${ }^{4}$ ， Douglas J Long ${ }^{5,6}$ ， Morgan Churchill ${ }^{7}$ ， Evan Martin ${ }^{8}$, \\ Sarah J Boessenecker ${ }^{2,9}$ \\ ${ }^{1}$ Department of Geology and Environmental Geosciences, College of Charleston, Charleston, South Carolina, United States \\ 2 Mace Brown Museum of Natural History, College of Charleston, Charleston, South Carolina, United States \\ 3 Museum of Paleontology, University of California, Berkeley, Berkeley, California, United States \\ 4 New Jersey State Museum, Trenton, New Jersey, United States \\ 5 Department of Ichthyology, California Academy of Sciences, San Francisco, California, United States \\ 6 Department of Biology, St. Mary's College, Moraga, California, US \\ 7 Department of Biology, University of Wisconsin-Oshkosh, Oshkosh, Wisconsin, United States \\ 8 San Diego Natural History Museum, San Diego, California, United States \\ 9 School of Museum Studies, University of Leicester, Leicester, United Kingdom \\ Corresponding Author: Robert W Boessenecker \\ Email address: boesseneckerrw@cofc.edu
}

The extinct giant shark Otodus megalodon is the last member of the predatory megatoothed lineage and is reported from Neogene sediments from nearly all continents. The timing of the extinction of $O$. megalodon is thought to be Pliocene, although reports of Pleistocene teeth fuel speculation that $O$. megalodon may still be extant. The longevity of the Otodus lineage (Paleocene to Pliocene) and its conspicuous absence in the modern fauna begs the question: when and why did this giant shark become extinct? Addressing this question requires a densely sampled marine vertebrate fossil record in concert with a robust geochronologic framework. Many historically important basins with stacked Otodus-bearing Neogene marine vertebrate fossil assemblages lack well-sampled and welldated lower and upper Pliocene strata (e.g. Atlantic Coastal Plain). The fossil record of California, USA, and Baja California, Mexico, provides such an ideal sequence of assemblages preserved within well-dated lithostratigraphic sequences. This study reviews all records of $O$. megalodon from post-Messinian marine strata from western North America and evaluates their reliability. All post-Zanclean 0 . megalodon occurrences from the eastern North Pacific exhibit clear evidence of reworking or lack reliable provenance; the youngest reliable records of $O$. megalodon are early Pliocene, suggesting an extinction at the early-late Pliocene boundary $(\sim 3.6 \mathrm{Ma})$, corresponding with youngest occurrences of $O$. megalodon in Japan, the North Atlantic, and Mediterranean. This study also reevaluates a published dataset, thoroughly vetting each occurrence and justifying the geochronologic age of each, as well as excluding several dubious records. Reanalysis 
of the dataset using Optimal Linear Estimation resulted in a median extinction date of 3.51 $\mathrm{Ma}$, somewhat older than a previously proposed Pliocene-Pleistocene extinction date (2.6 Ma). Post-middle Miocene oceanographic changes and cooling sea surface temperature may have resulted in range fragmentation, while alongside competition with the newly evolved great white shark (C. carcharias) during the Pliocene may have led to the demise of the megatoothed shark. Alternatively, these findings may also suggest a globally asynchronous extinction of $O$. megalodon. 
1 The early Pliocene extinction of the mega-toothed shark Otodus megalodon: A view from

2 the eastern North Pacific

3 Robert W. Boessenecker ${ }^{1,2,3}$, Dana J. Ehret ${ }^{4}$, Douglas J. Long ${ }^{5,6}$, Morgan Churchill ${ }^{7}$, Evan $\operatorname{Martin}^{8}$, and Sarah J. Boessenecker ${ }^{3,9}$

$5{ }^{1}$ Department of Geology and Environmental Geosciences, College of Charleston, Charleston,

6 South Carolina, USA

7 2University of California Museum of Paleontology, University of California, Berkeley,

8 California, USA

$9{ }^{3}$ Mace Brown Museum of Natural history, College of Charleston, Charleston, South Carolina,

10 USA

$11{ }^{4}$ New Jersey State Museum, Trenton, New Jersey, USA

$12{ }^{5}$ Department of Ichthyology, California Academy of Sciences, San Francisco, California, USA

$13{ }^{6}$ Current address: Department of Biology, St. Mary's College, Moraga, California, USA

$14{ }^{7}$ Department of Biology, University of Wisconsin-Oshkosh, Oshkosh, Wisconsin, USA

$15{ }^{8}$ San Diego Natural History Museum, Department of Paleontology, San Diego, California, USA

$16{ }^{9}$ School of Museum Studies, University of Leicester, Leicester, UK

17 Corresponding author:

18 Robert W. Boessenecker ${ }^{1,2,3}$ 


\section{Abstract}

22 The extinct giant shark Otodus megalodon is the last member of the predatory megatoothed

23 lineage and is reported from Neogene sediments from nearly all continents. The timing of the

24 extinction of $O$. megalodon is thought to be within the Pliocene, although reports of Pleistocene

25 teeth have fueled speculation that $O$. megalodon may still be extant. The longevity of the Otodus

26 lineage (Paleocene to Pliocene) and its conspicuous absence in the modern fauna begs the

27 question: when and why did this giant shark become extinct? Addressing this question requires a

28 densely sampled marine vertebrate fossil record in concert with a robust geochronologic

29 framework. Many historically important basins with stratigraphically stacked Otodus-bearing

30 Neogene marine vertebrate fossil assemblages lack well-sampled and well-dated lower and

31 upper Pliocene strata (e.g. Atlantic Coastal Plain). The fossil record of California, USA, and

32 Baja California, Mexico, provides such an ideal sequence of assemblages preserved within well-

33 dated fossil-rich lithostratigraphic sequences. This study reviews all records of $O$. megalodon

34 from post-Messinian marine strata from western North America and evaluates their reliability.

35 All post-Zanclean O. megalodon occurrences from the eastern North Pacific exhibit clear

36 evidence of reworking or lack reliable provenance; the youngest reliable records of $O$.

37 megalodon are early Pliocene, suggesting an extinction at the early-late Pliocene boundary $(\sim 3.6$

$38 \mathrm{Ma}$ ), corresponding with youngest occurrences of $O$. megalodon in Japan, the North Atlantic,

39 and Mediterranean. This study also reevaluates a published dataset, thoroughly vetting each

40 occurrence and justifying the geochronologic age of each, as well as excluding several dubious

41 records. Reanalysis of the dataset using Optimal Linear Estimation resulted in a modal extinction

42 date of 3.6 Ma, older than a previously proposed Pliocene-Pleistocene extinction date (2.6 Ma).

43 Environmental and oceanographic causes for the decline and/or extinction of $O$. megalodon 
44 seem unlikely, whereas competition with the newly evolved great white shark (C. carcharias)

45 during the Pliocene cannot yet be excluded as a possible mechanism.

46 Introduction

47 The giant predatory shark Otodus megalodon has been reported from Miocene and some

48 Pliocene sediments from all continents except Antarctica, indicating a near worldwide

49 distribution (Cappetta, 2012). Although some controversy exists regarding the generic allocation

50 of this species (Purdy et al., 2001; Ehret et al., 2009a, 2012, and references therein; Cappetta,

51 2012), O. megalodon appears to represent the terminal chronospecies of a Paleocene to Pliocene

52 lineage including $O$. obliquus and earlier species formerly placed within Carcharocles such as $O$.

53 angustidens, generally characterized by steadily increasing body size through time (Ward and

54 Bonavia, 2001; Ehret et al., 2009a; Cappetta, 2012; Ehret et al., 2012). Otodus megalodon is

55 estimated to have attained a body length of 16-18 m (Gottfried et al., 1996; Pimiento and Balk,

56 2015), representing one of the largest sharks to ever exist, and one of a few marine

57 superpredators of the Miocene, alongside macrophagous sperm whales (Bianucci and Landini,

58 2006; Lambert et al., 2010) and the less well known giant shark Parotodus benedeni (Kent,

59 1999; Kent and Powell, 1999; Purdy et al., 2001). Although aspects of the morphology,

60 evolution, and paleoecology of $O$. megalodon and other members of the Otodus lineage have

61 been investigated, including phylogenetic affinities (Applegate and Espinosa-Arrubarrena, 1996;

62 Gottfried and Fordyce, 2001; Nyberg et al., 2006; Ehret et al., 2009a, 2012), body size (Gottfried

63 et al., 1996; Gottfried and Fordyce, 2001; Pimiento and Balk, 2015), tooth histology (Bendix-

64 Almgreen, 1983), vertebral morphology and growth (Gottfried and Fordyce, 2001; MacFadden et

65 al., 2004), physiology (Ferrón, 2017), and reproductive behavior and habitat preference (Purdy et

66 al., 2001; Pimiento et al., 2010), until recently (e.g. Pimiento and Clements, 2014; Pimiento et 
67 al., 2016) little attention has been directed at causes for the extinction or timing of its extinction.

68 A recent study (Pimiento and Clements, 2014) utilized an Optimal Linear Estimation analysis of

69 geochronologic data for $O$. megalodon records to estimate a late Pliocene (terminal Piacenzian;

$702.58 \mathrm{Ma}$ ) extinction for O. megalodon. However, the dataset utilized by Pimiento and Clements

71 (2014) contains problematic occurrence data (incorrect identifications, lack of provenance, poor

72 stratigraphic control, etc.). Examples of these problems, illuminated below, indicate that rigorous

73 reevaluation of the provenance of late Neogene O. megalodon specimens worldwide and their

74 geochronologic age is warranted.

75 In many regions, the lack of continuous fossiliferous strata of late Neogene age,

76 prominence of specimens with poor or dubious provenance, and stratigraphic uncertainty make

77 assessing the age and stratigraphic occurrence of O. megalodon records difficult (see Pimiento

78 and Clements, 2014:table s2 for records they excluded from their analysis for these reasons). The

79 stratigraphic record of the eastern North Pacific, primarily in California and Baja California,

80 includes fossiliferous marine strata with abundant marine vertebrates and excellent age control,

81 essentially preserving a nearly continuous marine fossil record from the middle Miocene through

82 Pleistocene (Boessenecker, 2013a; 2016). Other regions with abundant Neogene marine

83 vertebrate assemblages including fossils of $O$. megalodon either lack well-sampled Pliocene

84 intervals (e.g. Peru; the youngest assemblages such as Sacaco and Sud-Sacaco are late Messinian

85 in age (Ehret et al., 2012; di Celma et al., 2017) or lack well-sampled upper Pliocene intervals

86 (Neogene marine deposits of the Atlantic coastal plain; e.g. Ward, 2008). We review reported

87 occurrences of $O$. megalodon from the densely-sampled and well-dated Miocene and Pliocene

88 lithostratigraphic units in California and Baja California (Messinian-Gelasian equivalent),

89 historically renowned for extensive Cenozoic marine vertebrate assemblages (Jordan, 1922; 
90 Jordan and Hannibal, 1923; Mitchell, 1966; Barnes, 1977; Repenning and Tedford, 1977;

91 Domning, 1978; Welton, 1979; Warheit, 1992; Barnes, 1998; Deméré et al., 2003;

92 Boessenecker, 2011b, 2013a, 2016), and report several new specimens (Fig. 1; Table 1). We

93 further reevaluate some specimens of questionable provenance that appear to be reworked from

94 underlying strata, or are not well documented geographically and/or stratigraphically. This

95 review invited a reappraisal of the $O$. megalodon occurrence dataset published by Pimiento and

96 Clements (2014). We thoroughly vetted the geochronologic age control for each occurrence

97 (Appendix 1) using some of the criteria, methods, and reporting standards recommended and/or

98 utilized by earlier studies (Parham et al., 2012; Boessenecker and Churchill, 2015; Boessenecker

99 et al., 2018). We excluded several dubious records from their dataset, revised the geochronologic

100 range for most, and added several additional records and performed an Optimal Linear

101 Estimation (OLE) analysis with the revised data set in order to estimate the timing of extinction

102 of O. megalodon (Table 2, Appendix 1-2).

103

\section{Materials and methods}

105 We examined collections from several institutions (CAS, LACM, RMM, SDNHM, and UCMP;

106 see below) housing large collections of Neogene marine vertebrate fossils from the Pacific coast

107 of North America. From these collections we identified a total of 145 Otodus megalodon teeth in

108 lower Miocene through Pliocene deposits. This study (Fig. 1; Table 1) only focuses on those

109 specimens of Messinian (latest Miocene) or younger age $(\mathrm{n}=46)$ and does not consider specimens

110 predating the Messinian stage (Langhian, Serravallian, Tortonian; $\mathrm{n}=99$ ). Teeth of $O$. megalodon

111 were examined for evidence of reworking (e.g. abrasion, enameloid cracking, phosphatization,

112 fragmentation; e.g. Boessenecker et al., 2014), and details of provenance (collector, collection 
113 date, locality description, similarity of preservation with other material from the same locality) to

114 evaluate the likelihood of specimens being taphonomically autochthonous or parautochthonous

115 versus allochthonous, or mistakenly attributed to an incorrect locality. Because this study relied

116 upon existing collections of fossil specimens in museum collections and did not involve field

117 study, no permits for field collection were required.

118

119 Global Otodus megalodon occurrence

120 We re-evaluated the entire dataset published by Pimiento and Clements (2014:table S1, text S1;

121 Table 2, Appendix 1-2). Age justifications by these authors included limited references to the

122 peer-reviewed stratigraphic literature and in some cases relied solely upon paleontological

123 articles without examination of more recent published geological studies providing refined

124 geochronologic data. Paleontological studies frequently re-cite the paper first reporting a fossil

125 occurrence without citing subsequent geological refinements, but since stratigraphy is not static,

126 it is critical to exhaustively search for stratigraphic and geochronologic data published afterwards

127 (Parham et al., 2012). We have audited the dataset by identifying the intraformational

128 stratigraphic position of each occurrence (if applicable) and exhaustively citing relevant, up-to-

129 date publications with geochronologic dates, favoring microfossil age correlations and absolute

130 dates $\left({ }^{87} \mathrm{Sr} /{ }^{86} \mathrm{Sr}\right.$ ratios, radiometric dates from interbedded ash $/$ tuff/basalt, etc.) whenever

131 possible; in some cases, only member- or formation-level stratigraphic control is available. In

132 order to preserve our reasoning for future evaluation this information is presented in Appendix 2

133 of this study. In addition, we excluded occurrences where any one or more of the following types

134 of problems existed (see Appendix 2): 1) lack of sub-epochal age control (e.g. "middle Miocene-

135 Pliocene" or "Pliocene"); 2) lack of minimum age control, 3) all available voucher specimens 
136 residing in a private collection; 4) specimens lacking clear provenance (e.g. "specimen probably

137 collected from locality..."; 5) misidentified specimens that are not identifiable as Otodus

138 megalodon; 6) occurrence with revised minimum date falling entirely within the Miocene; 7)

139 occurrences where the estimated age is based on the occurrence of Otodus megalodon, leading to

140 a case of circular reasoning; and 8) unpublished occurrence data where the stratigraphy and

141 geochronology cannot be evaluated by the reader.

142

143 Optimal Linear Estimation Analysis (OLE)

144 Once we evaluated and revised a dataset of age occurrence data for Otodus megalodon, we them

145 treated them as historic sightings for implementation of an Optimal Linear Estimation (OLE)

146 model, as performed by Pimiento and Clements (2014) in their earlier study. Our revised dataset

147 of late occurrences of $O$. Megalodon comprises 43 data points, and includes fossils from around

148 the world (Appendix 1). Optimal Linear estimation has been found to be an accurate way of

149 assessing extinction times in the fossil record, as last known occurrences generally follow a

150 Weibull extreme value distribution (Clements et al. 2013; Solow, 2005; Wang \& Marshall,

151 2016).

152 To run our analysis, OLE was implemented in R, using a modified version of the same

153 code provided by Pimiento and Clements (2014; see Appendix 3) and same overall parameters.

154 We implemented 10,000 simulations, bootstrapping from a uniform distribution for each

155 simulation. The value reported below in results represents the modal estimate of extinction, with

156 the full range of extinction dates recovered also reported.

157

158 Geochronologic framework 
159 The traditional threefold division of the Pliocene and Pliocene-Pleistocene boundary set at 1.806

$160 \mathrm{Ma}$ (Gradstein et al., 2004) has recently been modified by the inclusion of the Gelasian stage

161 within the Pleistocene and designation of the Zanclean and Piacenzian stages as early and late

162 Pliocene (respectively), and a new Pliocene-Pleistocene boundary at 2.566 Ma (Gibbard et al.,

163 2009; Gradstein et al., 2012), which we follow herein. Stages of international usage are generally

164 referred to throughout (e.g. Messinian, Zanclean, Piacenzian, Gelasian) to alleviate confusion

165 between late Pliocene sensu lato (=Gelasian stage) and late Pliocene sensu stricto (=Piacenzian

166 stage); references to North American Land Mammal Ages (NALMAs; e.g. Clarendonian,

167 Hemphillian, Blancan) and local New Zealand stages (e.g. Opoitian) are also made. Note that

168 other recent studies in Pliocene-Pleistocene marine vertebrate paleontology followed the

169 compromise of Hilgen et al. (2012) in maintaining the Gelasian as the late Pliocene (e.g.

170 Boessenecker 2011b, 2013a, 2013b).

171

172 Institutional abbreviations

173 CAS, California Academy of Sciences, San Francisco, California, USA; LACM, Natural History

174 Museum of Los Angeles County, Los Angeles, California, USA; RMM, Riverside Municipal

175 Museum, Riverside, California, USA; SDNHM, San Diego Natural History Museum, San

176 Diego, California, USA; UCMP, University of California Museum of Paleontology, Berkeley,

177 California, USA

178

179 Results

180 Systematic Paleontology

181 
182 Chondrichthyes Huxley, 1880

183 Lamniformes Berg, 1958

184 Otodontidae Glikman, 1964

185 Otodus Agassiz, 1838

186 Otodus megalodon Agassiz, 1843

187

188

Referred material

189 LACM 59836, 59837, 115989, 129982, and SDNHM 53167, Capistrano Formation (LACM

190 localities 4437, 5792, 61520, and SDNHM locality 3842); LACM 148311, 148312, and 149739,

191 Fernando Formation (LACM localities 7321 and 7481); RMM A597-1, A597-9A, A597-9B, and

192 A597-12, Lomita Marl (no locality number); LACM 59065 and SDNHM 73462, Niguel

193 Formation (LACM locality 65187 and SDNHM locality 4080, respectively); LACM 10141,

194 LACM 11149, LACM 159028, Palos Verdes Sand and unnamed Pleistocene strata (LACM

195 locality 1066 and 7971); UCMP 219502, Purisima Formation (UCMP locality V-99875); LACM

196 10152, LACM 103448, LACM 156334, and SDNHM 29742, San Diego Formation (LACM

197 localities 1080, 1095, 4875 and SDNHM locality 3253); LACM 131149, SDNHM 23056, 23959

198 (four teeth with same number), 24448, 77430, and 77343, “upper” San Mateo Formation

199 (Lawrence Canyon local fauna; LACM locality 4297 and SDNHM locality 3161); CAS

200 72799.00, Santa Cruz Mudstone (no locality number); and LACM 29065-29067, 29069-29070, 201 and 29073-29078, Tirabuzón Formation (LACM locality 6579).

202

203 Diagnosis 
204 Crowns broad, triangular and erect, being broader and more vertical in anterior teeth and with

205 increasing posterior inclination distally; labial crown face relatively flat or mildly convex, often

206 showing short vertical infoldings of the enameloid at base of crown, lingual crown face

207 moderately convex; crown enameloid relatively thick; chevron-shaped band of thinner enameloid

208 on lingual crown face between base of crown and root (lingual neck), thicker in medial section

209 becoming thinner laterally and showing fine vertical striations; cutting edge with fine, even,

210 rounded serrations along entire margin, averaging 12-17 serrations per centimeter $(\mathrm{cm})$; lateral

211 cusplets lacking in adult teeth; root is labiolingually thick with two laterally divergent but

212 apicobasally shallow lobes, usually similar in size and not extending much laterally beyond the

213 lower margin of the crown; labial root face is relatively flat while the lingual root face is laterally

214 convex and thicker in the center with a pronounced nutritive foramen medially.

216 Taxonomic Note

217 The taxonomy of the megatoothed sharks is a topic that has been subject to much controversy

218 and debate. In the original description of the species, Agassiz (1843) referred Otodus megalodon

219 to the genus Carcharodon based on superficial morphological similarities in tooth shape and the

220 presence of serrations. Jordan and Hannibal (1923) recognized a difference between the extant

221 great white shark (Carcharodon carcharias) and the fossil serrated-edged megatoothed sharks,

222 erecting the genus Carcharocles for the latter. However, this taxonomic change was not adopted

223 into the literature until the late 1980s (Cappetta, 1987). Other generic names proposed for Otodus

224 megalodon include Procarcharodon Casier, 1960 and Megaselachus Glikman, 1964. Usage of

225 Carcharodon and Procarcharodon were challenged in the literature based on tooth morphology,

226 the fossil record, and taxonomic priority (Cappetta, 1987; Ehret et al., 2009a, 2012; Pimiento et 
227 al., 2010). Instead, Carcharocles is broadly accepted for the generic assignment of $O$. megalodon

228 in many recent studies (Ehret et al., 2009a; 2012; Pimiento and Clements, 2014; Boessenecker,

229 2016; Pimiento and Balk, 2015; Pimiento et al., 2016, 2010, 2017; Collareta et al., 2017). Some

230 recent publications have proposed uniting all megatoothed shark taxa included within Otodus

231 and Carcharocles in the genus Otodus. In this scenario, all non-serrated forms would belong to

232 the genus Otodus, whereas Eocene-Oligocene serrated forms C. auriculatus and C. angustidens

233 are designated to the subgenus Carcharocles, and C. chubutensis and C. megalodon belong to

234 their own subgenus Megaselachus (Zhelezko and Kozlov, 1999; Cappetta and Carvallo, 2006;

235 Cappetta, 2012). Recently, Shimada et al. (2017) further argued from a cladistic standpoint that

236 Carcharocles should be synonymized within Otodus in order to make the latter genus

237 monophyletic. We follow the reassignment of Isurus hastalis (or alternatively, Cosmopolitodus

238 hastalis) to the genus Carcharodon (Ehret et al., 2012) for similar reasons, and thus adopt the

239 reassignment of Carcharocles to Otodus. Because subgenera are generally not used as a

240 taxonomic convention in vertebrate paleontology, we do not use the subgeneric taxonomy of

241 Cappetta (2012).

\section{Occurrence Data}

244 Pliocene-aged teeth of Otodus megalodon have been recovered or reported from several

245 formations in California and Baja California (Fig. 1), including the Lomita Marl, Capistrano,

246 Fernando, Niguel, Purisima, San Diego, San Mateo, and Tirabuzón formations, the ages of which

247 are summarized below. These specimens exhibit a combination of morphological characters

248 including: a large overall size and labiolingual thickness, triangular shape, fine serrations, V-

249 shaped chevron on the lingual surface between the crown and root, and loss of lateral cusplets at 
250 the base of the crown. These characters, when observed together, indicate that the specimens

251 undoubtedly belong to $O$. megalodon. The only other sharks that could be confused with $O$.

252 megalodon during the late Miocene and early Pliocene are those belonging to Carcharodon $(C$.

253 hubbelli and C. carcharias), which have significantly smaller and labiolingually flatter teeth

254 lacking V-shaped chevrons and have coarser serrations. Therefore, we are confident in assigning

255 these specimens to $O$. megalodon. Additionally, we found that relatively few $O$. megalodon teeth

256 from eastern North Pacific Neogene sediments are present in museum collections; for example, a

257 total of 145 teeth from lower Miocene through Pliocene west coast deposits are represented in

258 LACM, SDNHM, and UCMP collections, primarily from California. In comparison, Purdy et al.

259 (2001:131) referred 82 specimens in addition to "several hundred isolated teeth" from the Pungo

260 River Limestone and Yorktown Formation at the Lee Creek mine alone, and countless additional

261 teeth exist in other collections and from other stratigraphic units from the Atlantic coastal plain.

262 Intense collecting at eastern North Pacific localities like the Sharktooth Hill Bonebed suggests

263 that this is not simply a case of collection bias and likely reflects genuine rarity (whether

264 biogenic or taphonomic) of $O$. megalodon teeth from Pacific coast deposits. An alternative

265 hypothesis is a geochronologically earlier extinction of $O$. megalodon in the Pacific basin than

266 the Atlantic.

267

268 Capistrano Formation

269 Stratigraphy: A thick section of late Neogene mudrock exposed in Orange County, California,

270 are divided into the Monterey/Temblor Formation (early late Miocene) and the Capistrano

271 Formation (latest Miocene to early Pliocene). In southern Orange County, the Capistrano

272 Formation is between 300-650 m thick, and includes a basal turbidite unit composed of breccia, 
273 sandstone, and siltstone, and an upper micaceous siltstone unit (Vedder, 1972; Ingle, 1979). The

274 Oso Member of the Capistrano is a coarse clastic tongue within the finer grained parts of the

275 Capistrano (not formally named as member) interpreted as the distal deposits of a delta within a

276 shallow embayment (Vedder et al., 1957; Barboza et al., 2017).

277 Occurrence: Specimens recovered from the Capistrano Formation (latest Miocene - early

278 Pliocene) include LACM 59836, 58937, 115989, 129982, and SDNHM 53167 (Fig. 2). SDNHM

27953167 is an incomplete upper left anterior tooth and represents the largest specimen from the

280 Capistrano Formation (Fig. 2 A-B). The other specimens from the Capistrano Formation

281 represent both anterior and posterolateral teeth and range from nearly complete (LACM 129982,

282 Fig. 2C-D; LACM 115989, Fig. 2G-H) to highly fragmented (LACM 59837, Fig. 2E-F; LACM

283 59836, Fig. 2I-J). SDNHM 53167 was collected from the upper siltstone unit of the Capistrano

284 Formation (SDNHM locality 3842) from a horizon approximately $30 \mathrm{~m}$ below a bed which

285 yielded diatoms of the earliest Pliocene Thalassiosira oestruppi zone (T.A. Deméré, pers.

286 comm., 11/2012; Deméré and Berta, 2005), dated at approximately 5.6-3.7 Ma in age (Barron

287 and Gladenkov, 1995; Barron and Isaacs, 2001).

288 Age Conclusion: This occurrence of $O$. megalodon can be best summarized as latest Miocene to 289 earliest Pliocene in age (latest Messinian to Zanclean equivalent, 5.6-3.7 Ma). Other specimens

290 from the Capistrano Formation (LACM 58936, 59837, 115989, 129982) were collected from

291 unknown horizons within the Capistrano Formation. A record of Otodus megalodon was listed

292 by Pimiento and Clements (2014: table S1) from the Capistrano Formation and dated to 11.6-3.6

293 Ma, without explanation or an accompanying Paleobiology Database entry. Specimens reported

294 from the Oso Member of the Capistrano Formation by Barboza et al. (2017) are 6.6-5.8 Ma in

295 age (Messinian) based on the occurrence of the extinct horse Dinohippus interpolatus. 


\section{Fernando Formation}

298 Stratigraphy: The Fernando Formation of Eldridge and Arnold (1907) is a poorly defined unit of

299 Pliocene marine sediments in the Ventura and Los Angeles basins of southern California

300 (Eldridge and Arnold, 1907; Woodring et al., 1946; Vedder, 1972; Squires, 2012). The Fernando

301 Formation unconformably overlies several Miocene units, including the terrestrial Sycamore

302 Canyon Member of the Puente Formation and the marine Capistrano and Monterey Formations

303 (Vedder, 1972) in Orange County. The Fernando Formation was defined only on biostratigraphic

304 age and includes numerous lithologies (Eldridge and Arnold, 1907; Squires, 2012). Because of

305 confused relationships with other late Neogene marine rocks in southern California (e.g. Pico,

306 Towsley, and Repetto formations) and poor exposure, the stratigraphy and age of various

307 outcrops assigned to the Fernando formation remains uncertain.

308 Occurrence: Eldridge and Arnold (1907) listed a single occurrence of Otodus megalodon (as

309 Carcharodon rectus, a junior synonym of $O$. megalodon) from the Shatto Estate locality;

310 however, no photograph, specimen number, or repository information was given and thus it is

311 not possible to unambiguously interpret this record. Eldridge and Arnold (1907) also reported the

312 shark Isurus planus (as Oxyrhina plana) in addition to numerous mollusks indicating a late

313 Pliocene to Middle Pleistocene age (C. L. Powell, II, pers. comm., 6/2013). Isurus planus is only

314 represented in upper Oligocene through lower upper Miocene sediments (Chattian-Tortonian

315 equivalent; Boessenecker, 2011b:14). The lack of reliable provenance casts doubt on the validity

316 of this record and the reported presence of I. planus suggests a Miocene age; this record is not

317 considered further. 
319 (LACM 148311 and 148312) from Eagle Glen in Riverside County (LACM locality 7321) and a

320 single specimen (LACM 149739) from nearby LACM locality 7481. LACM 148311 and 148312

321 are fragmentary with thin and abraded enameloid, and the serrations have been eroded away.

322 LACM 149739 is now missing, though an existing photograph shows this specimen is

323 fragmented yet exhibits unabraded cutting edges.

324 Conclusion: Owing to poor understanding of the lithostratigraphy and age of the Fernando

325 Formation at this locality, the age of these specimens - whether reworked or not - is equivocal,

326 and the age of the Fernando Formation is best summarized as Pliocene to Pleistocene.

327 Accordingly, this record was excluded from the OLE.

328

329

\section{Imperial Formation}

330 Stratigraphy: The Imperial Formation is a thick succession of fossiliferous mudrocks deposited

331 on the west side of the Salton Trough in Imperial County, California, and exposed best in the

332 vicinity of the Coyote, Fish Creek, and Vallecito Mountains (Powell, 1988; Winker and Kidwell,

333 1991; Dorsey et al., 2011). The Imperial Formation was upgraded to group rank and subdivided

334 into the Latrania and Deguynos members by Winker and Kidwell (1991), though we follow

335 Powell (2008) in not recognizing this as the redefined units have not been formally described.

336 The Fish Creek-Vallecito section of the Imperial Formation, the underlying Split Mountain

337 Group (Miocene), and the overlying Palm Springs Group (Pliocene-Pleistocene) has been the

338 focus of extensive stratigraphic studies investigating regional tectonics, magnetostratigraphy,

339 biostratigraphy, and the formation of the Colorado River (Dorsey et al., 2011). The Imperial

340 Formation has long been considered Pliocene (Hanna, 1926; Durham, 1954), and recent 
341 magnetostratigraphic work on the Fish Creek-Vallecito section indicates that the Imperial

342 Formation spans chrons C3An.1r to C3n.1n, indicating an age of 6.43-4.187 for the entire unit

343 (Dorsey et al., 2011).

344 Occurrence: A single tooth (USNM 324542) of "Carcharodon arnoldi" was reported by Hanna

345 (1926) from the Imperial Formation at Garnet Cañon (USGS locality 3922) in the Coyote

346 Mountains of Imperial County, California, near the type locality of the extinct walrus Valenictus

347 imperialensis (Mitchell, 1961). This specimen is clearly a tooth of Otodus megalodon owing to

348 its large size and clearly preserved V-shaped dental band. It is unclear whether this came from

349 the lower (Latrania) or upper (Deguynos) member of the formation.

350 Conclusion: By extrapolating magnetostratigraphy from the better studied Fish-Creek Vallecito

351 section, this occurrence of O. megalodon is latest Miocene to early Pliocene (6.43-4.187 Ma).

352

353 Lomita Marl

354 Stratigraphy: The Lomita Marl consists mostly of unconsolidated calcareous mudrocks and

355 sandstones exposed in the western Los Angeles basin in the vicinity of Torrance and Lomita

356 northeast of the Palos Verdes Hills, Los Angeles County, California (Grant and Gale, 1931;

357 Woodring et al., 1946; Fig. 1). The Lomita Marl is, in part, a lateral and temporal equivalent of

358 the Timms Point Silt and the San Pedro Sand (Woodring et al., 1946). Glauconite K/Ar dates of

359 3.0 Ma reported by Obradovich, (1965) suggest a Pliocene age, though most modern workers

360 consider the Lomita Marl to be middle Pleistocene in age based on aminostratigraphy and

361 magnetostratigraphy (Ponti, 1989; Dupré et al., 1991; Lajoie et al., 1991).

362 Occurrence: Otodus megalodon is represented from this unit by teeth of "Carcharodon branneri"

363 Jordan, 1922 (RMM A597-1, A597-12) and "Carcharodon leviathan" Jordan, 1922 (RMM 
364 A597-9A, A597-9B), both junior synonyms of $O$. megalodon; these specimens were collected in

365 a quarry that exposed the unconformable contact between the Miocene Monterey Formation and

366 Pleistocene Lomita Marl. These specimens are fragmented, abraded, with polished enameloid

367 and phosphatic matrix adhering in cracks. Mount (1974) noted that several marine vertebrate

368 fossils appear to be reworked from underlying Miocene rocks, supported by the preservation of

369 these specimens (e.g. Boessenecker et al., 2014).

370 Conclusion: These specimens appear to have been reworked or anthropogenically mixed with

371 middle Pleistocene sediment approximately 650 to $350 \mathrm{Ka}$ in age (See Purported Pleistocene and

372 Holocene records of Otodus megalodon).

373

374 Niguel Formation

375 Stratigraphy: The Niguel Formation is a unit of unconsolidated conglomerates, sandstones, and

376 siltstones exposed in the San Joaquin Hills in Orange County, California, deposited along the

377 southeastern margin of the Los Angeles Basin and unconformably overlying the Capistrano

378 Formation and other strata (Vedder, 1972). At SDNHM locality 4080, the Niguel Formation

379 unconformably overlies the lower-middle Miocene "Topanga" Formation (T.A. Deméré, pers.

380 comm., 2013). The base of the Niguel Formation is a conglomerate lag deposit (Vedder, 1972).

381 The Niguel Formation is rich in fossils and mollusks indicating a Pliocene age (Vedder, 1972)

382 possibly between 3.3 and 3.15 Ma (Powell et al., 2008). Based on fossils and lithostratigraphy,

383 Ehlig (1979) considered the Niguel Formation to be late Pliocene to Pleistocene in age,

384 estimating it to be 1-3 Ma (Kern and Wicander, 1974; Powell et al., 2008).

385 Occurrence: An abraded tooth fragment identifiable as Otodus megalodon (SDNHM 73462) was

386 collected from the basal conglomerate, along with teeth of other sharks including Carcharhinus 
387 sp., Carcharodon carcharias, C. hastalis, Galeocerdo sp., Hemipristis sp., Isurus planus, and

388 Myliobatis sp. Also recovered from this locality were tooth fragments of Desmostylus sp.,

389 earbones of a delphinid dolphin and a balaenid mysticete, and a pharyngeal tooth plate of the

390 sheepshead fish Semicossyphus. Another O. megalodon specimen, LACM 59065 from

391 Capistrano Highlands (LACM locality 65187), likely represents an upper anterior tooth (Fig. 4A-

392 B) and exhibits longitudinal cracks, abraded cutting edges, and a fragmented root.

393 Although certain marine vertebrates from SDNHM locality 4080 such as Carcharodon

394 carcharias and Delphinidae indet. are consistent with a Pliocene age for the Niguel Formation,

395 several other taxa are typical of older Miocene age. For example, the youngest records of

396 desmostylians occur in the Tortonian equivalent Santa Margarita Sandstone in Santa Cruz

397 County, and the Monterey Formation in Orange County, California (Mitchell and Repenning,

398 1963; Barnes, 1978; Domning, 1978; Barnes, 2013). Other Miocene vertebrates from this

399 locality include C. hastalis and Isurus planus; C. hastalis is replaced by C. hubbelli at

400 approximately 8-7 Ma (Ehret et al., 2012), whereas confirmable records of I. planus are

401 Tortonian and older (Boessenecker, 2011b:14).

402 Conclusion: The taphonomic condition of these $O$. megalodon specimens and presence of strictly

403 Miocene marine vertebrates, and the occurrence of these specimens in the basal conglomerate of

404 the Niguel Formation all indicate they were reworked from the early to middle Miocene

405 "Topanga" Formation. Accordingly, this record was excluded from the OLE.

406

407 Purisima Formation

408 Stratigraphy: The Purisima Formation comprises a series of lightly consolidated sandstones,

409 mudrocks, and diatomites of latest Miocene and Pliocene age representing shoreface to offshore 
410 sedimentation, and is exposed mostly west of the San Andreas fault in the vicinity of Santa Cruz,

411 Halfmoon Bay, and Point Reyes in central and Northern California (Cummings et al., 1962;

412 Norris, 1986; Powell, 1998; Powell et al., 2007; Boessenecker et al., 2014). The Purisima

413 Formation is richly fossiliferous, including fossils of sharks, bony fishes, marine birds, and

414 marine mammals (see Boessenecker, 2011b, 2013b; Boessenecker et al., 2014, and references

415 therein).

416 Occurrence: A single nearly complete upper anterior tooth of $O$. megalodon (UCMP 219502;

417 Fig. 5) was reported by Boessenecker (2016) from the basal bonebed of the Miocene to Pliocene

418 Purisima Formation near Santa Cruz, California (UCMP locality V99875). Only the root lobes

419 and a small portion of the crown base are missing, and longitudinal enameloid cracks are evident

420 lingually and labially. The basal meter of the Purisima Formation is composed of glauconitic

421 sandstone and a matrix-supported conglomerate with abundant vertebrate skeletal elements

422 mantling an erosional surface with $\sim 1$ m of relief, unconformably overlying the upper Miocene

423 Santa Cruz Mudstone (Clark, 1981; Boessenecker et al., 2014). Glauconite from the base of the

424 Purisima Formation has yielded a K/Ar date of 6.9 $\pm 0.5 \mathrm{Ma}$ (Clark, 1966; Powell et al., 2007). A

425 tuff bed approximately $30 \mathrm{~m}$ above the base of the Purisima Formation has been

426 tephrochronologically correlated with 5.0 \pm 0.3 Ma tephra in the Pancho Rico Formation (Powell

427 et al., 2007).

428 Conclusion: This locality (UCMP locality V99875) can be summarized as 6.9-5.3 Ma in age, or

429 latest Miocene (Messinian equivalent).

430

431 San Diego Formation 
432 Stratigraphy: The San Diego Formation comprises approximately 85-90 m of unconsolidated

433 Pliocene and Pleistocene sandstones, mudrocks, and conglomerates of terrestrial and marine

434 origin deposited via extensional tectonics within a graben in the vicinity of San Diego, California

435 between Pacific Beach and northern Baja California (Deméré 1982, 1983; Wagner et al., 2001;

436 Vendrasco et al., 2012). The San Diego Formation is informally divided into two members: a

437 "lower" sandstone member that is entirely marine in origin, and an "upper" sandstone and 438 conglomeratic member that is marine and terrestrial (Deméré 1982, 1983). Although earlier

439 studies concluded that the San Diego Formation was approximately 3-1.5 Ma in age (late

440 Pliocene to early Pleistocene: Deméré 1983), more recent estimates based on paleomagnetism

441 and correlation with patterns of eustatic sea level change suggest an early Pliocene age (Zanclean

442 equivalent) for parts of the "lower" member of the San Diego Formation (Wagner et al., 2001).

443 Furthermore, Vendrasco et al. (2012) reported the San Diego Formation to ranges in age from

$444 \quad 4.2-1.8 \mathrm{Ma}$.

445 Occurrence: A single upper right anterior or anterolateral tooth missing part of the root and crown (SDNHM 29742; Fig. 6A-B) was reported from the basal San Diego Formation near La

447 Joya in Baja California (SDNHM locality 3253; Ashby and Minch, 1984). The tooth is almost 448 equilateral, with a slight curvature to the right. A V-shaped chevron, fine serrations, and three 449 small nutrient foramina are present on the lingual surface of the root. Three additional specimens 450 (Fig. 6C-H) are recorded from LACM collections from San Diego County: LACM 156334

451 (LACM locality 1095), a broken tooth with thinned and longitudinally cracked enameloid, 452 abraded surfaces and broken edges; LACM 10152 (LACM locality 4875), a broken but 453 unabraded tooth with longitudinally cracked enameloid; LACM 103448 (LACM locality 1080), 
454 a fragment of enameloid shell missing the orthodentine core. These other specimens are less

455 complete than SDNHM 29742 are not stratigraphically located within the San Diego Formation.

456 Conclusion: The only specimen with precise stratigraphic data (SDNHM 29742) was collected

457 from the basal unconformity of the San Diego Formation. This occurrence can be summarized as

458 approximately 4.2 Ma in age (early Pliocene); a minimum age of $3.6 \mathrm{Ma}$ is provided by

459 magnetostratigraphy of strata higher up in the San Diego Formation (Wagner et al., 2001).

460

461 San Mateo Formation

462 Stratigraphy: The San Mateo Formation is a thin package of unconsolidated sandstones and

463 conglomerates, which crop out in the vicinity of Oceanside in San Diego County, California. It is

464 considered a temporal equivalent of the Oso Member of the Capistrano Formation (Barnes et al.,

465 1981; Domning and Deméré, 1984), and Vedder (1972) refers to it as a coarse clastic tongue

466 within the Capistrano Formation. It consists of a lower unit composed of massive, fine-grained

467 sandstones with occasional muddy lenses, sparse pebbles and cobbles, and an upper unit of

468 complexly bedded sandstones and conglomerates; a sharp erosional surface at the base of the

469 upper unit divides the formation (Barnes et al., 1981; Domning and Deméré, 1984). Fossil

470 assemblages from the lower and upper units have been termed the San Luis Rey River and

471 Lawrence Canyon local faunas, respectively (Barnes et al., 1981). Domning and Deméré (1984)

472 interpreted the lower unit to represent middle or inner shelf deposition, and the upper unit to

473 represent the distal margin of a submarine fluvial delta system. A diverse marine vertebrate

474 assemblage including sharks, bony fish, marine birds, and marine mammals is now known from

475 the San Mateo Formation at Oceanside (Barnes et al., 1981; Domning and Deméré, 1984; Long,

476 1994). Due to the lack of macroinvertebrates or microfossils, age estimates for the San Mateo 
477 Formation have been established based on vertebrate biochronology, including terrestrial

478 mammals and mancalline auks (Domning and Deméré 1984). Barnes et al. (1981) considered

479 both the lower and upper units to be correlative with the Hemphillian NALMA. However,

480 Domning and Deméré (1984) reported that the presence of Aepycamelus indicated the lower unit

481 is slightly older, perhaps late Clarendonian to early Hemphillian in age (approximately 10-7 Ma;

482 Tedford et al., 2004), and correlated the upper unit with the late Hemphillian NALMA (7 Ma to

483 4.9-4.6 Ma; Tedford et al., 2004). Based on the presence of mancalline auks found in other rocks

484 of early Pliocene age (and the lack of late Pliocene mancalline taxa as from the San Diego

485 Formation), Domning and Deméré (1984) indicated an early Pliocene age for the upper unit of

486 the San Mateo Formation.

487 Occurrence: The San Mateo Formation has yielded a number of partial Otodus megalodon teeth 488 including: SDNHM 23056, 23959 (several teeth in a lot), 24448, 77430, 77343, and LACM

489131149 (Fig.7). One specimen catalogued in the lot SDNHM 23959 (Fig. 7I-J) and another tooth 490 (SDNHM 24448, Fig. 7C-D) represent the most complete teeth recovered from the San Mateo

491 Formation. SDNHM 23959 represents an upper right anterolateral tooth consistent with $O$.

492 megalodon despite missing the apex, having worn and chipped mesial and distal cutting edges,

493 and broken root lobes. SDNHM 24448 represents an upper left posterolateral tooth (Fig. 7C-D).

494 The specimen is missing a portion of the right root lobe and is missing some enameloid on the 495 lingual surface of the crown.

496 Conclusion: Teeth of Otodus megalodon occur in both the lower and upper units of the San

497 Mateo Formation (Domning and Deméré 1984; Barnes and Raschke, 1991), and occurrences

498 from the upper unit are here summarized as earliest Pliocene in age (5.33 to $4.6 \mathrm{Ma}$ ). 
500 Santa Cruz Mudstone

501 Stratigraphy: At the type section west of Santa Cruz (Santa Cruz County) of the Santa Cruz

502 Mudstone is a monotonous succession of jointed, indurated, and siliceous mudrocks (siltstone

503 and porcelanite), which conformably overlies the Santa Margarita Sandstone and is in turn

504 unconformably overlain by the Purisima Formation. In the vicinity of Point Reyes, thick,

505 massively bedded, indurated and fractured siliceous mudrocks were originally considered by

506 Galloway (1977) to represent both the Monterey and Drakes Bay formations, but were remapped

507 by Clark et al. (1984) as the somewhat younger Santa Cruz Mudstone. Near Bolinas,

508 foraminifera representative of the Delmontian California benthic foraminiferal Stage ( 7-5 Ma;

509 Barron and Isaacs, 2001) has been recorded, in addition to a diatom flora typical of Diatom Zone

510 X (Clark et al., 1984), which was later refined to subzone A of the Nitzschia reinholdii zone by

511 Barron (in Zeigler et al., 1997), equivalent to 7.6-6.5 Ma (Barron and Isaacs, 2001). Fossil

512 bivalves from the Santa Cruz Mudstone at Bolinas indicate deposition at about $>500 \mathrm{~m}$ depth

513 (Zeigler et al., 1997). Fossil vertebrates from the Santa Cruz Mudstone include the baleen whale

514 Parabalaenoptera baulinensis (Zeigler et al., 1997), the sea cow Dusisiren dewana (initially

515 reported as Dusisiren species D by Domning, 1978), a herpetocetine baleen whale

516 (Boessenecker, 2011a:8), and a number of unpublished marine mammals (R.W. Boessenecker,

517 pers. obs.) including a phocoenid porpoise (cf. Piscolithax), an albireonid dolphin, fragmentary

518 odobenid and otariid bones, and earbones of indeterminate balaenopterid mysticetes.

519 Occurrence: A single tooth of O. megalodon was reported from "Bolinas Bay" by Jordan (1907:

520 figure 15) as the holotype specimen of "Carcharodon branneri". Unfortunately, searches for

521 additional locality information at CAS were unsuccessful. Specimens reported by D.S. Jordan in

522 various publications were originally curated at Stanford University, the collections of which 
523 were later transferred to CAS; it is possible that some of these specimens were never transferred

524 to CAS (S. Mansfield, pers. comm., 2013; D. Long, pers. obs., 2013). Ransom (1964) published

525 township and range coordinates for this locality, suggesting that the type was collected near the

526 west shore of the Bolinas Lagoon in the vicinity of the Bolinas County Park. However, this area

527 is covered by Quaternary alluvium with nearby exposures of sparsely fossiliferous Pliocene to

528 Pleistocene Merced Formation. It is more likely that the original locality information is correct,

529 and that the type specimen was collected from exposures (or as float) of the Santa Cruz

530 Mudstone along the northwestern shore of Bolinas Bay (Jordan and Hannibal, 1923; also see

531 Jordan, 1907) or possibly from as far west as Duxbury Reef (where the majority of twentieth and

532 twenty-first century vertebrate collections from this unit have been made). This specimen was

533 erroneously assigned to the Purisima Formation by Pimiento and Clements (2014: table S2) and

534 assigned an age of 5.3-2.6 Ma without explanation; the Purisima Formation does not crop out

535 anywhere within $25 \mathrm{~km}$ of Bolinas (Clark et al. 1984). Bones of fossil marine mammals are often

536 collected as float from these beaches.

537 Conclusion: If this specimen was collected from the Santa Cruz Mudstone near Bolinas, then it

538 likely represents an older 7.6-6.5 Ma record. Because this record falls within the Messinian, it 539 was included within the OLE.

\section{Tirabuzón Formation}

542 Stratigraphy: The Tirabuzón Formation consists of unconsolidated fossiliferous sandstone

543 exposures in the vicinity of Santa Rosalia along the eastern side of the northern Baja California

544 Peninsula (Applegate, 1978; Applegate and Espinosa-Arrubarrena, 1981; Wilson, 1985).

545 Formerly mapped as the Gloria Formation, it was renamed the Tirabuzón Formation by Carreno 
546 (1982) after abundant spiral burrows of the ichnogenus Gyrolithes which leant the locality the

547 name "Corkscrew Hill." Paleodepth estimates for this unit range from 200-500 m (outer shelf to

548 slope) based on foraminifera (Carreno, 1982) to 55-90 m (middle shelf) based on ichnology

549 (Wilson, 1985). The Tirabuzón Formation unconformably overlies the upper Miocene Boleo

550 Formation, and is in turn unconformably overlain by the lower to upper Pliocene Infierno

551 Formation (Holt et al., 2000). Holt et al. (2000) reported an ${ }^{40} \mathrm{Ar} /{ }^{39} \mathrm{Ar}$ date of $6.76 \pm 0.9 \mathrm{Ma}$ from

552 an andesitic interbed within the Boleo Formation, constraining a lower limit for the age of the

553 Tirabuzón Formation. The age of the Tirabuzón Formation was considered Pliocene by

554 Applegate (1978) and Applegate and Espinosa-Arrubarrena (1981), and approximately 4-3 Ma

555 (Zanclean equivalent) by Barnes (1998). Mollusks reported from the overlying Infierno

556 Formation indicate a maximum age of early Pliocene for that unit (Johnson and Ledesma-

557 Vasquez, 2001), therefore constraining a minimum age of early Pliocene for the Tirabuzón

558 Formation. Shark and marine mammal fossils have previously been reported from the Tirabuzón

559 Formation near Santa Rosalia, including 34 shark taxa (including Otodus megalodon), an

560 indeterminate otariid, two balaenopterid mysticetes, a small pontoporiid dolphin (aff.

561 Pontoporia), an indeterminate phocoenid, two delphinids (Delphinus or Stenella sp., and aff.

562 Lagenorhynchus sp.), two kogiids (aff. Kogia sp. and cf. Scaphokogia sp.), and an indeterminate

563 physeterid (Applegate, 1978; Applegate and Espinosa-Arrubarrena, 1981; Barnes, 1998).

564 Occurrence: Small teeth of Otodus megalodon are relatively abundant in the Tirabuzón

565 Formation (Fig. 8), and include 14 partial teeth: LACM 29064-29067, and 29069-29078. Most of

566 these teeth, except for smaller fragments, exhibit the characteristic V-shaped chevron and most

567 still retain their fine serrations. The most complete specimens are two left posterolateral upper 
568 teeth, LACM 29065 (Fig. 8I-J), missing portions of the root lobes, and LACM 29076 (Fig. 8G-

$569 \mathrm{H})$, missing the apex of the crown and parts of the root lobes.

570 Conclusion: This occurrence of $O$. megalodon in the Tirabuzón Formation is estimated to be late

571 Miocene to early Pliocene (Messinian-Zanclean equivalent; 6.76-3.6 Ma).

572

573 Revisions to the Pimiento and Clements (2014) dataset

574 Prior to conducting the Optimal Linear Estimation (OLE) we thoroughly vetted every fossil

575 occurrence in the dataset published by Pimiento and Clements (2014: table S1; Table 2). We

576 encountered a number of issues requiring adjustments. Much of their dataset ( $88 \%$ of

577

occurrences) consists of dates binned to stages (e.g. assigned the boundary dates of a particular

578

stage or epoch). This is standard practice for paleobiological analyses (e.g. Pimiento et al., 2016)

579

like richness counts, but it artificially expanded the age range (e.g. older maxima and younger

580

minima) for occurrences where finer geochronological age control is available in the literature.

581 This artificially inflated the number of Piacenzian-stage occurrences of Otodus megalodon which

582 actually have older (e.g Zanclean) minimum dates ( $\mathrm{n}=13$ occurrences from Pimiento and

583 Clements, 2014; Table 2). In other cases, we updated out-of-date geochronologic data; out of

584 occurrences we did not exclude, we were able to update 25 out of 32 occurrences $(78 \%$ of the

585 dataset) originally reported by Pimiento and Clements (2014) based upon stratigraphic and

586 geochronologic studies not cited by these authors (Table 2).

587 We excluded 10 out of the original 42 occurrences which satisfied one or more rejection

588 criteria (see Materials and Methods, Appendix 2). Several occurrences did not possess

589 subepochal age control (criterion 1), and we excluded any occurrence data for Otodus megalodon

590 teeth where the finest age control possible was provided by a statement in the literature like "this 
591 locality is mapped as Pliocene" or "middle Miocene to Pliocene" without finer age control

592 (Luanda Formation, Angola; Canímar Formation, Cuba; Salada Formation, Mexico). Several

593 occurrences reported by Pimiento and Clements (2014) consist of unpublished records of $O$.

594 megalodon teeth from the Bone Valley Formation in various mines in Florida, dated to early

595 Pliocene; however, their stratigraphic justification refers to unpublished data in the FLMNH

596 online data base (criterion 8). An early Pliocene age is entirely consistent with other exposures of

597 the upper Bone Valley Formation (Morgan, 1994). However, we excluded these occurrences

598 because the stratigraphic interpretation cannot be evaluated based upon the peer-reviewed

599 literature alone. Other occurrences simply lacked strong provenance (criterion 4); for example,

600 one specimen of $O$. megalodon reported by Keyes (1972) from New Zealand had locality data on

601 a label stating "probably from the upper Miocene beds Older Wanganui Series of NZ Geological

602 Survey from between Wanganui and N. Plymouth"; $180 \mathrm{~km}$ of coastline separate these two

603 cities. We excluded this record for its lack of provenance. One purported Pliocene tooth of $O$.

604 megalodon was reported from the Highlands Limestone of Barbuda (Flemming and McFarlane,

605 1998); we excluded this record because geological studies indicate this unit is actually middle

606 Miocene in age (criterion 6) Brasier and Mather, 1975, and references therein). In one case, teeth

607 reported from the Bahia Inglesa Formation of Chile (Long, 1993) lacked intraformational

608 stratigraphic control (criteria 1, 2, 4), and assignment to the Miocene or Pliocene section of the

609 formation was not possible. The age control for two other localities (Luanda Formation, Angola;

610 "Main Vertebrate spot", Libya) was based on biochronology of the shark assemblage, with a

611 minimum age of early Pliocene being based on the presence of $O$. megalodon itself (Antunes,

612 1978; Pawellek et al., 2012). We excluded these records because inclusion of these records

613 within the OLE would constitute circular reasoning (criterion 7). Other occurrences were 
614 excluded because they appear to be misidentified teeth of Carcharodon carcharias (Cameron

615 Inlet Formation, Australia; Kemp, 1991: plate 30C; criterion 5) or the specimens in question still

616 reside in a private collection and therefore cannot be evaluated by scientists (Tangahoe

617 Formation, New Zealand; McKee 1994a; criterion 3).

618 We were also able to add several occurrences to the dataset (Table 2; Appendix 1),

619 including some published after the publication of Pimiento and Clements (2014) and some that

620 they were unaware of (e.g. Carrillo Puerto Formation, Mexico; Tokomaru Formation, New

621 Zealand); at least one occurrence (Daito Limestone, Kita-daito-jima, Japan; Table 2) originally

622 excluded by Pimiento and Clements (2014) was found to have stronger age control (Takayanagi

623 et al., 2010) than previously acknowledged (Pimiento and Clements, 2014: text S1), and was

624 included within the OLE.

625

626

627 Results of OLE Analysis

628 The total range of estimates of extinction age for Otodus megalodon in the OLE analysis 629 vary from 4.1-3.2 Ma, with a modal extinction date of 3.6 Ma (Fig. 9). Approximately $50 \%$ of 630 the extinction estimates indicate extinction between 4.1-3.6 Ma. Fewer than $2 \%$ of the extinction 631 estimates occur before 3.91 Ma, while fewer than $2 \%$ occur after 3.26 Ma. None of the extinction 632 dates estimated occurred post Zanclean, with no evidence of survival of $O$. megalodon into this 633 period or to the present

634

635 Discussion

636 
637 Purported Pleistocene and Holocene records of Otodus megalodon

638 The record of Otodus megalodon from the Lomita Marl (Jordan, 1922) is substantially younger

639 than many other records from California. However, as noted by Mount (1974), numerous sharks

640 and other marine vertebrates from the Lomita Quarry locality are only found elsewhere in middle

641 and late Miocene localities, such as Allodesmus (Jordan and Hannibal, 1923: plate 9J) and

642 Carcharodon hastalis (Jordan and Hannibal, 1923: plate 9E-F). Furthermore, shark teeth

643 including O. megalodon teeth were collected by quarry manager H. M. Purple (Anonymous,

644 1921; Mount 1974), without accompanying stratigraphic information, and it is unclear where in

645 the Lomita Quarry these specimens were collected. Hanna (in Jordan and Hannibal, 1923) notes

646 that the base of the Lomita Marl within the Lomita Quarry was a glauconitic sandstone with

647 abundant abraded whale bones, and that in addition to Miocene marine mammals and sharks,

648 Pleistocene terrestrial mammals and a single Pleistocene pinniped were present in the quarry.

649 This curious mixture of taxa suggests stratigraphic reworking of older fossil material; indeed, the

650 holotype specimen of the gastropod Mediargo mediocris was considered by Wilson and Bing

651 (1970:7) to be reworked from Pliocene sediments into the Lomita Marl. Woodring et al. (1946)

652 report that the Lomita Marl includes "beds of gravel consisting chiefly or entirely of limestone

653 pebbles and cobbles derived from the "Monterey" Shale. Locally huge boulders of soft Miocene

654 mudstone and Pliocene siltstone are embedded in calcareous strata." These specimens of $O$.

655 megalodon (RMM A597-1, A597-9A, and A597-9B) are fragmented, and strongly abraded with

656 polished enameloid, indicating reworking. Only RMM A597-12 showed little evidence of

657 abrasion, although taphonomic experiments on fossil teeth by Argast et al. (1987) noted that

658 abrasion is not a guaranteed outcome of transport or reworking. Lastly, anthropogenic mixing of

659 multiple strata during mining operations is also a possibility for seemingly older taxa in younger 
660 beds. Dynamite was used for mining in the quarry, which apparently "[brought] down bones of 661 whales, sea lions, land animals, chipped flints, pieces of charcoal, sea shells, shark's teeth, 662 arrowheads, all mixed together" (Anonymous, 1921). The report of $O$. megalodon from the 663 Pleistocene Lomita Marl could be due to reworking from the "Monterey" Formation, 664 anthropogenic mixing from mining operations, collection from underlying strata, poor record 665 keeping, or any combination of the above. In this context, teeth of $O$. megalodon from the 666 Lomita Marl are considered to be allochthonous (either by sedimentologic or anthropogenic 667 reworking) and thus not relevant to the consideration of the timing of the extinction of the 668 species.

669 Three teeth of Otodus megalodon (LACM 10141, 11194, and 159028) are questionably 670 recorded from the upper Pleistocene Palos Verdes Sand and unnamed strata at Newport Bay 671 Mesa (Fig. 10). LACM 11194 is now missing, but was found by an unknown collector prior to 6721915 from the North Pacific Avenue and Bonita Avenue intersection in northern San Pedro, 673 California. The locality is now built over, but was mapped as Palos Verdes Sand by Woodring et 674 al. (1946). LACM 10141, is a fragmentary tip of a tooth with longitudinally cracked enameloid 675 and abraded serrations (Fig. 10c-d), and was collected from unnamed strata along the Newport 676 Bay Mesa formerly considered to belong to the Palos Verdes Sand (collector and collection date 677 unknown); it is alternatively possible that this specimen was collected from an exposure (now 678 covered) of the Pliocene Fernando Formation (see Mount, 1969). LACM 159028 (Fig. 10a-b) 679 possesses the following dubious locality information: "Rosecranz Ave. Long Beach, Orange 680 Co.?" We note that Rosecrans Avenue is far from the Palos Verdes Hills and from Long Beach, 681 and that both Rosecrans Avenue and Long Beach are located within Los Angeles County. It is 682 also possible that this specimen is reworked from the underlying Puente Formation (L.G. Barnes, 
683 pers. comm., 2015). Alternatively, some Pliocene rocks are known in the Coyote Hills near

684 Rosecrans Avenue (Powell and Stevens, 2000), and the specimen may have been collected there.

685 It is not possible to unambiguously recognize any of these specimens as genuine Pleistocene

686 records of $O$. megalodon given the lack of provenance. We also note the similarity in

687 preservation (chiefly color) between LACM 159028 and teeth of $O$. megalodon from some

688 localities at Sharktooth Hill (middle Miocene "Temblor" Formation, Kern County). Kanakoff

689 (1956) only listed C. carcharias from this unit. Furthermore, a comprehensive study of the

690 ichthyofauna by Fitch (1970) only recorded C. carcharias. We hypothesize that LACM 11194

691 was a misidentified or mistranscribed specimen of $C$. carcharias and that the other two

692 specimens originated from a separate locality. Therefore, we conclude that no reliable records of

693 O. megalodon exist for Pleistocene deposits in the Los Angeles Basin

694 Several studies have reported teeth of Otodus megalodon dredged from the seafloor and

695 considered to be Pleistocene or even Holocene in age (Tschernezky, 1959; Seret, 1987; Roux and

696 Geistdoerfer, 1988). Dredged specimens from the south Pacific were reported by Tschernezky

697 (1959) and Seret (1987), whereas Roux and Geistdoerfer (1988) reported numerous specimens

698 from the Indian Ocean seafloor off the coast of Madagascar. Tschernezky (1959) and Roux and

699 Geistdoerfer (1988) both attempted to determine the age of the teeth by measuring the thickness

700 of adhering manganese dioxide nodules and applying published rates of $\mathrm{MnO}_{2}$ nodule growth.

701 Tschernezky (1959) reported a range of 24,406-11,333 years for the $\mathrm{MnO}_{2}$ nodule formation for

702 these teeth, and Roux and Geistdoerfer (1988) reported specimens with nodules with the

703 equivalent of 60-15 $\mathrm{Ka}$ of $\mathrm{MnO}_{2}$ growth. However, both studies assumed a constant rate of

704 nodule growth and interpreted these dates as indicating a latest Pleistocene extinction of $O$.

705 megalodon (Tschernezky, 1959; Roux and Geistdoerfer, 1988). Tschernezky (1959) argued that 
706 even if $O$. megalodon went extinct during the Middle Pleistocene ca. $500 \mathrm{Ka}$, his dredged $O$.

707 megalodon teeth should have had $\mathrm{MnO}_{2}$ coatings approximately $75 \mathrm{~mm}$ thick. Because

708 conditions favoring the formation and growth of $\mathrm{MnO}_{2}$ nodules are not necessarily constant over

709 geologic time (Purdy et al., 2001), these dates can only indicate when these teeth were exposed

710 to seawater and do not reflect geochronologic age. It is probable that these specimens were

711 concentrated on the seafloor through submarine erosion, winnowing, depositional hiatus, or a

712 combination thereof. Collections of numerous resistant vertebrate hardparts from these dredgings

713 (e.g. shark teeth and cetacean ear bones) support this suggestion. A more parsimonious scenario

714 is that these specimens are Pliocene (or Miocene) in age and were deposited in areas of slow

715 sedimentation with intermittent erosion, concentrating nodules and resistant marine vertebrate

716 skeletal elements (typically teeth and cetacean skull fragments) on the seafloor. Intermittent

717 periods of favorable chemistry fostered the formation and growth of $\mathrm{MnO}_{2}$ nodules and coatings,

718 and it is possible that these specimens have experienced numerous burial-exhumation cycles

719 (Boessenecker et al., 2014). Lastly, because no extrinsic absolute or biostratigraphic age data

720 exist for these specimens, the maximum age of these specimens is ultimately unknown and

721 cannot be considered to represent post-Pliocene occurrences (Applegate and Espinosa-

722 Arrubarrena, 1996; Purdy et al., 2001).

723

724 Timing of the extinction of Otodus megalodon in the eastern North Pacific

Although numerically less abundant than in deposits of the Atlantic Coastal Plain, fossil

726 teeth of Otodus megalodon have been reported from numerous middle Miocene localities in

727 California and Baja California (Jordan and Hannibal, 1923; Mitchell, 1966; Deméré et al., 1984).

728 Late Miocene occurrences of O. megalodon include the Almejas (Barnes, 1992), Monterey 
729 (Barnes, 1978), "lower” San Mateo (Domning and Deméré, 1984), Capistrano (Barboza et al.,

730 2017; this study), and Purisima formations (Boessenecker, 2016; this study), Santa Cruz

731 Mudstone (Jordan and Hannibal, 1923; this study), and Santa Margarita Sandstone (Barnes,

732 1978; Domning, 1978). Pliocene occurrences in California (reviewed above) are restricted to the

733 Capistrano, Fernando, “upper” San Mateo, basal San Diego, and Tirabuzón formations (Fig. 11).

734 In the context of dubious provenance or clear evidence of reworking for specimens younger than

735 these, we do not consider any post-early Pliocene records of O. megalodon to be reliable and

736 putative Quaternary specimens areparticularly dubious. Several specimens of $O$. megalodon are

737 now recorded from the basal San Diego Formation, which is as old as 4.2 Ma (Wagner et al.,

738 2001; Vendrasco et al., 2012), and we interpret these records as earliest Pliocene (Zanclean

739 equivalent; Fig. 11). The lack of $O$. megalodon specimens and abundant Carcharodon

740 carcharias teeth in younger sections of the San Diego Formation is paralleled in the Purisima

741 Formation at Santa Cruz. Although Carcharodon carcharias teeth are common within well-

742 sampled bonebeds, no teeth of $O$. megalodon have been discovered from the Pliocene section of

743 either unit. However, teeth of $O$. megalodon are rare within established Miocene marine

744 vertebrate collections relative to C. hastalis or C. carcharias (e.g., within the Sharktooth Hill

745 Bonebed, approximately $80+$ specimens of $C$. hastalis are recorded versus 9 teeth of $O$.

746 megalodon in UCMP collections; accessed 10/23/2018). In summary, specimens discussed

747 herein are entirely latest Miocene or earliest Pliocene in age (Messinian-Zanclean equivalent;

748 Fig. 11). Qualitative assessment of the reliable occurrences of $O$. megalodon in California and

749 Baja California suggests extinction of this taxon during the early Pliocene, perhaps during the

750 Zanclean stage or near the Zanclean-Piacenzian boundary (ca. 4-3 Ma; Fig. 11). 
752

753

754

755

756

757

758

759

760

761

762

763

764

765

766

767

768

769

770

771

772

773

774

\section{A worldwide view of Otodus megalodon extinction}

The fossil record of Otodus megalodon in other regions lends support to an early Pliocene (Zanclean) extinction (Figs. 9, 11). Previously described records of Pliocene age possibly relevant to temporally constraining the extinction of $O$. megalodon include occurrences from the eastern U.S.A., Japan, Australia, New Zealand, western Europe (Belgium, Spain, United Kingdom, Denmark), southern Europe (Italy), Africa (Libya), and South America (Chile, Ecuador, Peru, Venezuela).

In deposits around the North Sea, Otodus megalodon has been reported from the Miocene, Pliocene, and Pleistocene (Bendix-Almgreen, 1983; Donovan, 1988). A tooth from the upper Miocene Gram Formation of Denmark was interpreted by Bendix-Almgreen (1983:23-24) as representing the youngest record of O. megalodon from the eastern North Atlantic. A tooth of O. megalodon from the Pliocene to Pleistocene Red Crag Formation of eastern England was mentioned by Donovan (1988), although the majority of marine vertebrate remains - marine mammals in particular - show evidence of reworking including abrasion, polish, and phosphatization and furthermore typically consist of dense elements with relatively high preservation potential (e.g. cetacean tympanoperiotics, teeth and tusks, and osteosclerotic beaked whale rostra; Owen, 1844, 1870; Lydekker, 1887). This evidence suggests that marine vertebrate material has been reworked from preexisting strata predating the Red Crag Formation; indeed, the Red Crag unconformably overlies the Eocene London Clay and the lower Pliocene Coralline Crag Formation (Zalasiewicz et al., 1988), and marine vertebrate remains may date to the Eocene-Pliocene depositional hiatus (or erosional lacuna) between the London Clay and overlying Red Crag Formation, or may have been reworked from the Coralline Crag Formation. A single record from the Piacenzian of France is cited by Cappetta (2012) from Gervais (1852), 
775 but no geographic or stratigraphic information is given by Gervais (1852:173) and this record 776 cannot be evaluated.

777 In a review of the stratigraphic range of Pliocene to Pleistocene elasmobranchs from

778 Italy, Marsili (2008) indicated that $O$. megalodon disappeared from the record during the

779 Zanclean ( 4 Ma) and that no Piacenzian records existed, contra Pimiento and Clements (2014:

780 table S1). In their discussion of the shark fauna of Malta, Ward and Bonavia (2001) considered

781 O. megalodon to have become extinct in the early Pliocene (but without further comment). Other

782 early Pliocene (Zanclean equivalent) records of O. megalodon from western Europe and the

783 Mediterranean region include the Huelva Formation of Spain (Garcia et al., 2009) and unnamed

784 strata in the Sabratah Basin of northwestern Libya (Pawellek et al., 2012). Elsewhere in Africa,

785 O. megalodon is recorded from the early Pliocene of Angola (Antunes, 1978).

786 In a summary of Mesozoic and Cenozoic ichthyofaunas from Japan, Yabumoto and

787 Uyeno (1995) reported that Otodus megalodon is widely known from Miocene strata and occurs

788 in the lower Pliocene, but not from younger upper Pliocene and Pleistocene rocks. Subsequently,

789 a review by Yabe et al. (2004) reported widespread occurrences of $O$. megalodon in the earliest

790 Pliocene (Zanclean) and a few late early Pliocene records (Piacenzian), and considered $O$.

791 megalodon to have gone extinct in the late early Pliocene or late Pliocene. Three post-Zanclean

792 occurrences were listed by Yabe et al. (2004): one is uncertainly Piacenzian, another Zanclean or

793 Piacenzian, and one strictly Piacenzian in age. However, these specimens were not figured by

794 Yabe et al. (2004) and it is unclear whether or not they are reworked.

795 An early Pliocene (Zanclean or Piacenzian) extinction of Otodus megalodon seems to be

796 reflected in the fossil record of Australia and New Zealand. Late Miocene occurrences of $O$.

797 megalodon are common from both landmasses (Keyes, 1972; Kemp, 1991; Fitzgerald, 2004). 
798 Several early Pliocene records of O. megalodon have been reported from Australia (Kemp, 1991;

799 Fitzgerald, 2004), including a single specimen from the lower Pliocene Cameron Inlet Formation

800 (Zanclean-Piacenzian correlative; Kemp, 1991; Fitzgerald, 2004). However, judging from

801 Kemp's (1991: plate 30C) illustration, this specimen is a misidentified Carcharodon carcharias

802 tooth owing to its small size, lack of a preserved chevron, and relatively large serrations. Keyes

803 (1972) reported several specimens ranging in age from early Pliocene to Pleistocene age, but

804 many of them have tenuous provenance. For example, one such specimen (included in the

805 analysis by Pimiento and Clements 2014) can only be pinpointed to a $180 \mathrm{~km}$ section of

806 coastline. Only a single published Pliocene tooth of Otodus megalodon from New Zealand has

807 reliable provenance, a specimen collected from Patutahi Quarry on the North Island. According

808 to Keyes (1972), strata at the quarry correspond to the local New Zealand Opoitian Stage (5.33-

$8093.6 \mathrm{Ma}$ ); accordingly, this tooth represents the youngest reliable record of $O$. megalodon from

810 New Zealand.

811 In South America, Otodus megalodon is known continuously from at least the middle

812 Miocene to the lowermost Pliocene in the Pisco Basin of Peru (Muizon and de Vries, 1985; Ehret

813 et al., 2012). However, owing to the absence of well-sampled younger marine vertebrate

814 assemblages, it is unclear if this simply reflects an artifact of preservation. Otodus megalodon

815 has also been reported from the latest Miocene-early Pliocene of Ecuador (Longbottom, 1979).

816 Although O. megalodon has been reported from the well-sampled uppermost Miocene to lower

817 Pliocene Bahia Inglesa Formation of Chile (Long, 1993), the exact age of this occurrence is

818 imprecisely known (Walsh and Hume, 2001; Walsh and Naish, 2002). On the Caribbean coast of

819 South America, O. megalodon is continuously known from middle Miocene through lower 
820 Pliocene deposits, with the youngest specimens occurring in the lowermost Pliocene (Zanclean821 correlative; Aguilera et al., 2004).

822 Paralleling the record in Venezuela, abundant Miocene records of $O$. megalodon exist in

823 the western North Atlantic and Caribbean, with the youngest specimens consistently being

824 earliest Pliocene in age (Flemming and McFarlane, 1998; Purdy et al., 2001; Ward, 2008). In

825 deposits of the Atlantic coastal plain of the United States, teeth of $O$. megalodon are abundant

826 within the lower Pliocene Sunken Meadow Member of the Yorktown Formation (Purdy et al.,

827 2001; Ward, 2008), but absent from the upper Pliocene Rushmere and Moore House members of

828 the Yorktown Formation (Ward, 2008). The extinction of O. megalodon was interpreted by Ward

829 (2008) to have occurred during the time recorded by the unconformity and depositional hiatus of

830 uncertain duration between the Sunken Meadow and Rushmere members. A number of possible

831 Pleistocene occurrences of $O$. megalodon from Florida are present in FLMNH collections, but

832 originate from temporally mixed fossil assemblages and quarry spoil piles (D.J. Ehret, pers. obs. 833 2015).

834 We interpret the absence of O. megalodon in the Rushmere and Moore House members

835 of the Yorktown Formation, upper San Diego Formation, and "upper" parts of the Purisima

836 Formation to be biochronologically real and reflect the genuine absence of this taxon. Given the

837 intense collecting of these localities by amateur and professional paleontologists alike, collection

838 bias is not likely a factor in determining the stratigraphic occurrence of $O$. megalodon.

839 Results of the OLE analysis based upon our revised version of the dataset (Table 2,

840 Appendix 1) incorporating current stratigraphic and geochronologic data indicate that Otodus

841 megalodon was most likely extinct by $3.6 \mathrm{Ma}$ and perhaps even as early as $4.1 \mathrm{Ma}$ (maximum)

842 and certainly no later than $3.2 \mathrm{Ma}$ (minimum; Figs. 9, 11), strongly indicating an extinction 
843 during the Zanclean stage or close to the Zanclean-Piacenzian boundary (3.6 Ma). This global

844 estimate compares well with the qualitative approach for $O$. megalodon occurrence data in the

845 eastern North Pacific, and consistent identification of minimum ages near the Zanclean-

846 Piacenzian boundaries is consistent with a globally synchronous extinction at or around 3.6 Ma.

847 We note that the separation between the maximum and minimum inferred extinction dates

848 ( 970,000 years; 4.1-3.2 Ma) from the OLE are substantially narrower than those results (3.66

849 million years; 3.5 Ma to $160 \mathrm{ky}$ in the future) reported by Pimiento and Clements (2014:2, fig.

850 1). Pimiento and Clements, in their results, focus on range of dates that result in a cumulative

$85150 \%$ probability of extinction, which give a range of extinction dates from 3.5-2.6 Ma. If we

852 follow this reasoning, and focus on the cumulative $50 \%$ probability of extinction found in our

853 study, we still get a narrower range of possible extinction times, between 4.1-3.6 Ma, or a range

854 of 500,000 years, versus the 900,000 of Pimiento and Clements (2014).

855 Perhaps more critical than the narrower range of modeled extinction dates is the earlier

856 shift in modal extinction date by nearly 1 million years relative to Pimiento and Clements (2014).

857 Geologically speaking, one million years seems trivial, but the difference between the two

858 reconstructed extinction dates is critical given that this extinction occurred quite recently; an

859 earlier date now poses problems for the supposed synchronicity of Plio-Pleistocene marine

860 mammal extinctions and/or faunal turnover (Pimiento et al., 2017; but see Boessenecker, 2013a).

861 Recently, Wang and Marshall (2016:4) noted that the "poorly resolved ages of many of the fossil

862 occurrences" of the Pimiento and Clements (2014) dataset led a wide confidence interval in their

863 OLE. Indeed, the results of macroevolutionary studies of extinction timing are sensitive to the

864 quality of available dates (Price et al., 2018). Our finer resolution highlights the importance of

865 carefully vetting the provenance of each reported occurrence and thoroughly exploring the 
866 geological literature for such fossil occurrences - critical for any study of biochronology (Price et

867 al., 2018) as well as selecting fossil calibrations for molecular clock dating (Parham et al., 2012).

868

869 Possible causes for the extinction of Otodus megalodon

870 Determination of the timing of the extinction of Otodus megalodon is a necessary step in

871 identifying potential causal factors contributing to its demise (Pimiento and Clements, 2014;

872 Pimiento et al., 2016). Although testing various hypotheses in a quantitative manner is beyond

873 the scope of this article, some comments regarding potential biotic and physical drivers are

874 appropriate given the revised extinction date presented herein. Abiotic drivers such as changes in

875 climate, upwelling, currents, sea level, and paleogeography are possible determinants in the

876 decline of the otodontid lineage (Pimiento et al., 2016). Physical events coincident with a "mid"-

877 Pliocene extinction include: 1) a decrease in upwelling in the eastern North Pacific (Barron,

878 1998), 2) increased seasonality of marine climates (Hall, 2002); 3) a period of climatic warming

879 and permanent El-Niño like conditions in the equatorial Pacific (Wara et al., 2005; Fedorov et

880 al., 2013), 4) followed by late Pliocene global cooling (Zachos et al., 2001), 5) closure of the

881 Panama seaway and restriction of currents and east-west dispersal among marine organisms

882 (Collins et al., 1996; Haug et al., 2001; O’Dea et al., 2016; Jaramillo et al., 2017), and 6) stable

883 eustatic sea level during the early Pliocene, 7) followed by eustatic sea level fall related to initial

884 glaciation during the late Pliocene (Miller et al., 2005). Some of these changes in oceanic

885 circulation and upwelling were regional, and therefore do not represent likely causes in the

886 extinction of $O$. megalodon (if the extinction was indeed globally synchronous; e.g. Pimiento and

887 Clements, 2014); however, these events may have been, in part, responsible for range

888 fragmentation. Long term cooling following the middle Miocene Climatic Optimum (Zachos et 
889 al., 2001) may have reduced the geographic range of this species (Purdy, 1996; Dickson and

890 Graham, 2004; but see Pimiento et al., 2016; Ferrón, 2017). However, a robust analysis of

891 worldwide geographic distribution in O. megalodon found no change in the latitudinal

892 distribution coincident with changes in global climate (Pimiento et al., 2016).

893 The lack of evidence for a climatic or geographic driver of $O$. megalodon extinction

894 suggests that a biotic driver is probably responsible (Pimiento et al., 2016). Within the eastern

895 North Pacific (ENP), many "archaic" marine mammal taxa became extinct during the early

896 Pleistocene (Gelasian stage, 2 Ma; Boessenecker, 2013a, 2013b), but the revised extinction of

897 O. megalodon (this study) seems to have pre-dated this $(\sim 3.6 \mathrm{Ma})$. The appearance of the modern

898 marine mammal fauna appears to have occurred by the early Pliocene in the North Atlantic and

899 western South Pacific (Whitmore, 1994; Fitzgerald, 2005; Boessenecker, 2013a), suggesting

900 globally asymmetric origination of modern marine mammal genera and species (Boessenecker,

901 2013a), in contrast with an apparently synchronous extinction of O. megalodon (Pimiento and

902 Clements, 2014; this study). Many extant genera of cetaceans first appeared during the Pliocene

903 (Fordyce and Muizon, 2001), apparently temporally coincident with the extinction of $O$.

904 megalodon, but with uncertain relevance. Other biotic effects have been hypothesized to have

905 affected or been driven by O. megalodon. Recently described macrophagous sperm whales

906 appear to have been diverse worldwide in the middle and late Miocene, were similar in size to $O$.

907 megalodon, and were likely competing apex predators (Lambert et al., 2010). A high diversity of

908 small-bodied baleen whales during the middle Miocene is implicated in supporting such an

909 assemblage of gigantic predators (Lambert et al., 2010; Collareta et al., 2017). Similarly,

910 Lindberg and Pyenson (2006) noted that the extinction of O. megalodon is roughly

911 contemporaneous with the earliest fossil occurrences of killer whales (Orcinus) in the fossil 
912 record, and perhaps competition with killer whales during the Pliocene could have acted as a

913 driver in the extinction of $O$. megalodon. However, the Neogene fossil record of Orcinus is

914 limited to two occurrences: an isolated tooth from Japan (Kohno and Tomida, 1993), and the

915 well-preserved skull and skeleton of Or. citoniensis from the late Pliocene of Italy (Capellini,

916 1883). Furthermore, Or. citoniensis was small in comparison to extant Or. orca (est. 4 m body

917 length: Heyning and Dahlheim, 1988) and possessed a higher number of relatively smaller teeth

918 and narrower rostrum (Bianucci, 1996), and was probably not an analogous macrophagous

919 predator. Because fossils of Orcinus are not widespread during the Pliocene, claims of

920 competition between O. megalodon and Orcinus are problematic. Furthermore, the decline and

921 loss of cosmopolitan macrophagous physeteroids (Tortonian-Messinian; Lambert et al., 2010)

922 appears to have predated the early Pliocene extinction of $O$. megalodon by several million years.

923 Evolutionary interactions with baleen whales have also been implicated for the Otodus

924 lineage (Collareta et al., 2017). Lambert et al. (2010, 2016) suggested that higher diversity of of 925 small-bodied mysticetes during the middle Miocene drove the evolution of killer sperm whales;

926 similarly, this could have driven body size increases in O. megalodon. Cetacean diversity peaked

927 in the middle Miocene and began to decrease in the late Miocene (Lambert et al., 2010; Marx

928 and Uhen, 2010), and maximum body length amongst fossil mysticetes increased during the late

929 Miocene and Pliocene (Lambert et al., 2010), heralding the appearance of modern giants such as

930 Balaena, Balaenoptera, Eschrichtius, Eubalaena, and Megaptera. Despite the increase in

931 maximum body size among mysticetes and apparently coincidental extinction of $O$. megalodon

932 during the Pliocene, numerous small-bodied archaic mysticetes persisted into the Pliocene

933 (Bouetel and Muizon, 2006; Whitmore and Barnes, 2008; Collareta et al., 2017) and even

934 Pleistocene (Boessenecker, 2013a), complicating this relationship. A modal extinction date of 
9353.6 for O. megalodon pre-dates the extinction of certain dwarf mysticetes such as Balaenula

936 (Piacenzian-Gelasian; Barnes, 1977), Herpetocetus (Calabrian-Ionian; Boessenecker, 2013b) and

937 various dwarf balaenopterids (Deméré, 1986; Boessenecker, 2013a). Indeed, further study of rare

938 late Pliocene marine mammals is necessary to further elucidate potential competition with $O$.

939 megalodon, extinctions, and faunal dynamics (Pimiento et al., 2017).

940 Another potential biotic factor in the extinction of Otodus megalodon is the evolution of

941 the modern great white shark, Carcharodon carcharias (Pimiento et al., 2016). It gradually

942 evolved from the non-serrated Carcharodon hastalis during the late Miocene, transitioning first

943 into the finely serrated Carcharodon hubbelli approximately 8-7 Ma, then evolved into the

944 coarsely serrated C. carcharias approximately 6-5 Ma (Ehret et al., 2009a, 2012; Boessenecker,

945 2011b; Long et al., 2014). However, in the western North Atlantic, C. carcharias is absent in the

946 early Pliocene Sunken Meadow Member of the Yorktown Formation (Purdy et al., 2001; Ward,

947 2008), and in its place is C. hastalis (=Isurus hastalis and I. xiphodon in Purdy et al., 2001).

948 Carcharodon carcharias instead occurs higher in the Rushmere Member of the Yorktown

949 Formation (Müller, 1999). This suggests that the appearance of C. carcharias in the Atlantic may

950 have been delayed relative to the Pacific. Pawellek et al. (2012) reported an earliest Pliocene fish

951 assemblage on the Mediterranean coast of Libya that included C. carcharias and O. megalodon;

952 clarifying the timing of first appearance of $C$. carcharias in ocean basins outside the Pacific is

953 necessary, but beyond the scope of this study. Nevertheless, the timing of O. megalodon

954 extinction appears to overlap with the final widespread global occurrence of $C$. carcharias in the

955 early Pliocene. It is critical to note that a single putative tooth of $C$. carcharias has been reported

956 from the middle Miocene Calvert Formation and has been identified as evidence supposedly

957 disproving the C. hastalis-C. hubbelli-C. carcharias transition (Purdy, 1996; Gottfried and 
958 Fordyce, 2001), although Ehret et al. (2012) indicated this specimen is a misidentified juvenile

959 O. megalodon tooth.

960 The development of serrations in Carcharodon hubbelli suggests a refined ability to prey

961 upon warm-blooded prey relative to other large lamnid and carcharhinid sharks (Frazzetta, 1988;

962 Ehret et al., 2009a, 2009b, 2012). Perhaps trophic competition with the newly evolved $C$.

963 carcharias contributed to the extinction of Otodus. megalodon, in which adult C. carcharias

964 would have been in the same size range and likely would have competed with juvenile $O$.

965 megalodon. Owing to its global scope, the first appearance of modern C. carcharias during the

966 early Pliocene is a likely candidate for the driver behind the extinction of $O$. megalodon. Further

967 investigations regarding body size trends in the Otodus and Carcharodon lineages, the $C$.

968 hastalis-C. hubbelli-C. carcharias anagenetic lineage in the Pacific basin and elsewhere (Fig.

969 11), and the timing of C. carcharias first appearances and O. megalodon last appearances in the

970 Atlantic and other ocean basins are necessary to evaluating these hypotheses of extinction drivers

971 of O. megalodon.

972

973 Conclusions

974 Fossil teeth of Otodus megalodon have been reported from Miocene, Pliocene, and Pleistocene

975 aged strata in California (USA) and Baja California (Mexico). Critical examination of

976 Pleistocene specimens and their stratigraphic context clearly indicate that they are reworked,

977 have poor provenance, or the specimens are missing (or some combination thereof), making

978 evaluation impossible. Specimens of late Pliocene age, such as those from the Niguel Formation,

979 also appear to be reworked from older strata. Early Pliocene specimens from the Capistrano

980 Formation, Imperial Formation, lowermost San Diego Formation, upper San Mateo Formation, 
981 and Tirabuzón Formation appear to represent the youngest autochthonous (or parautochthonous)

982 records, whereas numerous $O$. megalodon records of middle and late Miocene age have been

983 reported. Optimal Linear Estimation analysis of a revised global dataset of Otodus megalodon

984 occurrences strongly suggests that $O$. megalodon was extinct by the end of the early Pliocene

985 (3.6 Ma), in remarkable concordance with our qualitative result based on the record from the

986 eastern North Pacific. Extinction of $O$. megalodon at 3.6 Ma appears to pre-date Pliocene-

987 Pleistocene faunal turnover of marine mammals, and the extinction of O. megalodon may instead

988 be related to late Miocene-Pliocene range fragmentation, declining numbers of small-bodied

989 mysticete whales, and the evolution of modern Carcharodon carcharias. This study further

990 dispels publicly held opinions that Otodus megalodon may still be extant, and demonstrates that

991 Otodus megalodon did not survive to the end of the Pliocene. OLE results of O. megalodon

992 extinction generated from our revised dataset highlight the importance of critically evaluating the

993 locality provenance and stratigraphic control of individual fossil occurrences. Testing these

994 revised hypotheses by the reporting of additional unpublished records of $O$. megalodon or

995 clarifying the age of poorly constrained fossil occurrences may result in further shifts and

996 refinements to the modal, maximum, and minimum extinction dates but absolutely requires

997 careful assessment of geochronology and provenance.

998

999

1000 Acknowledgments

1001 This study benefited from discussions with J. Ashby, M. Balk, M. DeJong, T.A. Deméré, J.

1002 Duran, R.E. Fordyce, A. Gale, J. Geisler, M.D. Gottfried, S. Mansfield, F.A. Perry, C. Pimiento, 1003 and K. Shimada. We thank the following, who expedited access to collections under their care: 
1004 L.G. Barnes, J. Bryant, T.A. Deméré, J. El Adli, M. Goodwin, P. Holroyd, S. McLeod, F.A.

1005 Perry, K. Randall, and V. Rhue. Thanks to S. McLeod, V. Rhue, and J. Velez-Juarbe for

1006 curatorial assistance. We are grateful for the careful comments of C.L. Powell, II, K. Shimada,

1007 an anonymous reviewer and the editor K. De Baets, whose detailed comments improved the

1008 quality of an earlier draft of this study.

1009

1010 References

1011

1012

1013

1014

1015

1016

1017

1018

1019

1020

1021

1022

1023

1024

1025

1026

1027

1028

1029

1030

1031

1032

1033

1034

1035

1036

1037

1038

1039

1040

Agassiz LJR. 1838. Recherches sur les poissons fossiles. Tome III (livr. 11). Neuchatel: Imprimérie de Petitpierre.

Agassiz LJR. 1843. Recherches sur les poissons fossiles. Tome III (livr. 15-16). Neuchatel: Imprimerie de Petitpierre.

Aguilera OA, Garcia L, and Cozzuol MA. 2004. Giant-toothed white sharks and cetacean trophic interaction from the Pliocene Caribbean Paraguana Formation. Paläontologische Zeitschrift 82:204-208.

Anonymous. 1921. Life extension bulletin. Advertising supplement to the Torrance Herald, Torrance, California 1:1.

Antunes MT. 1978. Faunes ichthyologiques du Néogène supérieur d'Angola, leur age, remarques sur le Pliocéne marin en Afrique australe. Ciênces da Terra (UNL) 4:59-90.

Applegate SP. 1978. Phyletic studies. Part 1. Tiger sharks. Universidad Nacional Autonoma de Mexico, Instituto de Geologia, Revista 2:55-64.

Applegate SP, and Espinosa-Arrubarrena L. 1981. The geology and selachian paleontology of Loma del Tirabuzon (Corkscrew Hill), Santa Rosalia, B.C.S. In: Ortlieb L, and Roldan J, eds. Geology of northwestern Mexico and Arizona. Hermosillo, Mexico: Universidad Nacional Autonoma Mexico, Instituto de Geologia, Estacion de Noroeste, 257-263.

Applegate SP, and Espinosa-Arrubarrena L. 1996. The fossil history of Carcharodon and its possible ancestor, Cretolamna: a study in tooth identification. In: Klimley AP, and Ainley DG, eds. Great white sharks: the biology of Carcharodon carcharias. San Diego, California: Academic Press, 19-36.

Argast S, Farlow JO, Gabet RM, and Brinkman DL. 1987. Transport-induced abrasion of fossil teeth: Implications for the existence of Tertiary dinosaurs in the Hell Creek Formation, Montana. Geology 15:927-930.

Ashby JR, and Minch JA. 1984. The Upper Pliocene San Diego Formation and the occurrence of Carcharodon megalodon at La Joya, Tijuana, Baja California, Mexico. In: Minch JA, and Ashby JR, eds. Miocene and Cretaceous Depositional Environments, Northwestern Baja California, Mexico. Los Angeles, California: American Association of Petroleum Geologists, Pacific Section, 19-28. 
1041 Barboza MM, Parham JF, Santos GP, Kussman BN, and Velez-Juarbe J. 2017. The age of the

1042

1043

1044

1045

1046

1047

1048

1049

1050

1051

1052

1053

1054

1055

1056

1057

1058

1059

1060

1061

1062

1063

1064

1065

1066

1067

1068

1069

1070

1071

1072

1073

1074

1075

1076

1077

1078

1079

1080

1081

1082

1083

1084

1085

1086
Oso Member, Capistrano Formation, and a review of fossil crocodylians from California. PaleoBios 34:1-16.

Barnes LG. 1977. Outline of eastern North Pacific fossil cetacean assemblages. Systematic Zoology 25:321-343.

Barnes LG. 1978. A review of Lophocetus and Liolithax and their relationships to the delphinoid family Kentriodontidae (Cetacea: Odontoceti). Natural History Museum of Los Angeles County Science Bulletin 28:1-35.

Barnes LG. 1992. The fossil marine vertebrate fauna of the latest Miocene Almejas Formation, Isla Cedros, Baja California, México. In: Carrillo-Chávez A, and Alvarez-Arellano A, eds. Primera Reunión Internacional sobre Geología de la Península de Baja California, Memorias. La Paz, Baja California Sur, Mexico: Universidad Autónoma de Baja California Sur, 147-166.

Barnes LG. 1998. The sequence of fossil marine mammal assemblages in Mexico. Avances en Investigacion: Paleontologia de Vertebrados, publicacion especial 1:26-79.

Barnes LG. 2013. A new genus and species of late Miocene paleoparadoxiid (Mammalia, Desmostylia) from California. Contributions in Science, Natural History Museum of Los Angeles County 521:51-114.

Barnes LG, Howard H, Hutchison JH, and Welton BJ. 1981. The vertebrate fossils of the marine Cenozoic San Mateo Formation at Oceanside, California. In: Abbott PL, and O'Dunn S, eds. Geologic Investigations of the coastal plain, San Diego County, California. San Diego, California: San Diego Association of Geologists, 53-70.

Barnes LG, and Raschke RE. 1991. Gomphotaria pugnax, a new genus and species of late Miocene dusignathine otariid pinniped (Mammalia: Carnivora) from California. Natural History Museum of Los Angeles County Contributions in Science 426:1-27.

Barron JA. 1998. Late Neogene changes in diatom sedimentation in the North Pacific. Journal of Asian Earth Sciences 16:85-95.

Barron JA, and Gladenkov AY. 1995. Early Miocene to Pleistocene diatom stratigraphy of Leg 145. Proceedings of the Ocean Drilling Program, Scientific Results 145:3-19.

Barron JA, and Isaacs CM. 2001. Updated chronostratigraphic framework for the California Miocene. In: Isaacs CM, and Rullkötter J, eds. The Monterey Formation - from rocks to molecules. New York, New York: Columbia University Press, 393-395.

Bendix-Almgreen SE. 1983. Carcharodon megalodon from the Upper Miocene of Denmark, with comments on elasmobranch tooth enameloid: coronoin. Bulletin of the Geological Society of Denmark 32:1-32.

Bianucci G. 1996. The Odontoceti (Mammalia, Cetacea) from Italian Pliocene. Systematics and phylogenesis of Delphinidae. Palaeontolographia Italica 83:73-167.

Bianucci G, and Landini W. 2006. Killer sperm whale: a new basal physeteroid (Mammalia, Cetacea) from the Late Miocene of Italy. Zoological Journal of the Linnaean Society 148:103-131.

Boessenecker RW. 2011a. Herpetocetine (Cetacea: Mysticeti) dentaries from the Upper Miocene Santa Margarita Sandstone of Central California. PaleoBios 30:1-12.

Boessenecker RW. 2011b. A new marine vertebrate assemblage from the Late Neogene Purisima Formation in central California, Part I: Fossil sharks, bony fish, birds, and implications for the age of the Purisima Formation west of the San Gregorio Fault. PalArch's Journal of Vertebrate Paleontology 8:1-30. 
1087 Boessenecker RW. 2013a. A new marine vertebrate assemblage from the Late Neogene Purisima

1088

1089

1090

1091

1092

1093

1094

1095

1096

1097

1098

1099

1100

1101

1102

1103

1104

1105

1106

1107

1108

1109

1110

1111

1112

1113

1114

1115

1116

1117

1118

1119

1120

1121

1122

1123

1124

1125

1126

1127

1128

1129

1130

1131

Formation in Central California, Part II: Pinnipeds and cetaceans. Geodiversitas 35:815940.

Boessenecker RW. 2013b. Pleistocene survival of an archaic dwarf baleen whale (Mysticeti: Cetotheriidae). Naturwissenschaften 100:365-371.

Boessenecker RW. 2016. First record of the megatoothed shark Carcharocles megalodon from the Mio-Pliocene Purisima Formation of Northern California. PaleoBios 33.

Boessenecker RW, and Churchill M. 2015. The oldest known fur seal. Biology Letters 11:21040835.

Boessenecker RW, Perry FA, and Schmitt JG. 2014. Comparative taphonomy, taphofacies, and bonebeds of the Mio-Pliocene Purisima Formation, Central California: strong physical control on marine vertebrate preservation in shallow marine settings. PLoS ONE 9:e91419.

Boessenecker SJ, Boessenecker RW, and Geisler JH. 2018. Youngest record of the extinct walrus Ontocetus emmonsi from the early Pleistocene of South Carolina and a review of North Atlantic walrus biochronology. Acta Palaeontologica Polonica 63:279-286.

Bouetel V, and Muizon C de. 2006. The anatomy and relationships of Piscobalaena nana (Cetacea, Mysticeti), a Cetotheriidae s.s. from the early Pliocene of Peru. Geodiversitas 28:319-395.

Brasier M, and Donahue H. 1975. The stratigraphy of Barbuda, West Indies. Geological Magazine 112:271-282.

Capellini G. 1883. Di Un'Orca fossile scoperta a cetona in Toscana. Memorie dell'Accademia delle Scienze dell'Instituto di Bologna 4:1-25.

Cappetta H. 1987. Handbook of Paleoichthyology, Volume 3B. Chondrichthyes II, Mesozoic and Cenozoic Elasmobranchii. Stuttgart: Gustav Fisher Verlag.

Cappetta H. 2012. Handbook of Paleoichthyology. Chondrichthyes (Mesozoic and Cenozoic Elasmobranchii: Teeth), vol. 3B. Stuttgart, Germany: Gustav Fisher.

Cappetta H, and Carvallo O. 2006. Les selaciens du Pliocene de la region d'Alba (Piemont, Italie Nordouest). Rivista Piemontese di Storia Naturale 27:33-76.

Carreno AL. 1982. Biostratigraphy at the Loma del Tirabuzón (Corkscrew Hill), Santa Rosalia Baja California Sur, Mexico. Third North American Paleontological Convention, Proceedings 1:67-69.

Clark JC. 1966. Tertiary stratigraphy of the Felton-Santa Cruz area, Santa Cruz Mountains, California Ph.D. Stanford University.

Clark JC. 1981. Stratigraphy, paleontology and geology of the central Santa Cruz mountains. United States Geological Survey Professional Paper 1168:1-51.

Clark JC, Brabb EE, Greene HG, and Ross DC. 1984. Geology of Point Reyes Peninsula and implications for San Gregorio Fault history. In: Crouch JK, and Bachman SB, eds. Tectonics and sedimentation along the California margin. Los Angeles, California: Pacific Section SEPM, 67-86.

Clements, CF, Worsfold NT, Warren PH, Collen B, Clark N, Blackburn TM, and Petchey OL. 2013. Experimentally testing the accuracy of an extinction estimator: Solow's optimal linear estimation model. Journal of Animal Ecology 82:345-354.

Collareta A, Lambert O, Landini W, Di Celma C, Malinverno E, Varas-Malca RM, Urbina M, and Bianucci G. 2017. Did the giant extinct shark Carcharocles megalodon target small 
1132

1133

1134

1135

1136

1137

1138

1139

1140

1141

1142

1143

1144

1145

1146

1147

1148

1149

1150

1151

1152

1153

1154

1155

1156

1157

1158

1159

1160

1161

1162

1163

1164

1165

1166

1167

1168

1169

1170

1171

1172

1173

1174

1175

1176

1177

prey? Bite marks on marine mammal remains from the late Miocene of Peru. Palaeogeography, Palaeoclimatology, Palaeoecology 469:84-91.

Collins LS, Coates AG, Berggren WA, Aubry MP, and Zhang J. 1996. The late Miocene Panama isthmian strait. Geology 24:687-690.

Cummings JC, Touring RM, and Brabb EE. 1962. Geology of the Northern Santa Cruz Mountains. California Division of Mines Geology Bulletin 181:179-220.

Deméré TA. 1982. Review of the lithostratigraphy, biostratigraphy and age of the San Diego Formation. In: Abbott PL, ed. Geologic studies in San Diego. San Diego: San Diego Association of Geologists, 127-134.

Deméré TA. 1983. The Neogene San Diego Basin: a review of the marine Pliocene San Diego Formation of southern California. In: LaRue DK, and Steel RJ, eds. Cenozoic Marine Sedimentation, Pacific Margin, USA. Los Angeles, California: Society of Economic Paleontologists and Mineralogists, 187-195.

Deméré TA. 1986. The fossil whale, Balaenoptera davidsonii (Cope 1872), with a review of other Neogene species of Balaenoptera (Cetacea: Mysticeti). Marine Mammal Science 2:277-298.

Deméré TA, and Berta A. 2005. New skeletal material of Thalassoleon (Otariidae:Pinnipedia) from the Late Miocene-Early Pliocene (Hemphillian) of California. Bulletin of the Florida Museum of Natural History 45:379-411.

Deméré TA, Berta A, and Adam PJ. 2003. Pinnipedimorph evolutionary biogeography. Bulletin of the American Museum of Natural History 279:32-76.

Deméré TA, Roeder MA, Chandler RM, and Minch JA. 1984. Paleontology of the middle Miocene Los Indios Member of the Rosarito Beach Formation, Northwestern Baja California, Mexico. In: Minch JA, and Ashby JR, eds. Miocene and Cretaceous Depositional Environments, Northwestern Baja California, Mexico. Los Angeles: Pacific Section A.A.P.G., 47-56.

Di Celma C, Malinverno E, Bosio G, Collareta A, Gariboldi K, Gioncada A, Molli G, Basso D, Varas-Malca RM, Pierantoni PP, Villa IM, Lambert O, Landini W, Sarti G, Cantalamessa G, Urbina M, and Bianucci G. 2017. Sequence stratigraphy and paleontology of the upper Miocene Pisco Formation along the western side of the lower Ica Valley (Ica Desert, Peru). Rivista Italiana di Paleontologia e Stratigrafia 123:255-273.

Dickson KA, and Graham JB. 2004. Evolution and consequences of endothermy in fishes. Physiological and Biochemical Zoology 77:998-1018.

Domning DP. 1978. Sirenian evolution in the North Pacific Ocean. University of California Publications in Geological Sciences 18:1-176.

Domning DP, and Deméré TA. 1984. New material of Hydrodamalis cuestae (Mammalia; Dugongidae) from the Miocene and Pliocene of San Diego County, California. Transactions of the San Diego Society of Natural History 20:169-188.

Donovan SK. 1988. Palaeoecology and taphonomy of barnacles from the Plio-Pleistocene Red Crag of East Anglia. Proceedings of the Geologists' Association 99:279-289.

Dorsey RJ, Housen BA, Janecke SU, Fanning CM, and Spears ALF. 2011. Stratigraphy record of basin development within the San Andreas fault system: Late Cenozoic Fish CreeVallecito basin, southern California. Geological Society of America Bulletin 123:771793.

Dupré WR, Morrison RB, Clifton HE, Lajoie KR, Ponti DJ, Powell CL, II, Mathieson SA, Sarna-Wojcicki AM, Leithold EL, Lettis WR, McDowell PF, Rockwell TK, Unruh JR, 
1178

1179

1180

1181

1182

1183

1184

1185

1186

1187

1188

1189

1190

1191

1192

1193

1194

1195

1196

1197

1198

1199

1200

1201

1202

1203

1204

1205

1206

1207

1208

1209

1210

1211

1212

1213

1214

1215

1216

1217

1218

1219

1220

1221

1222 and Yeats RS. 1991. Quaternary geology of the Pacific margin. In: Morrison RB, ed. Quaternary nonglacial geology: conterminous US. Boulder, Colorado: Geological Society of America, 141-213.

Durham JW. 1954. THe marine Cenozoic of southern California. California Division of Mines and Geology Bulletin 170:4.

Ehlig P. 1979. The late Cenozoic evolution of the Capistrano Embayment. Geologic Guide of the San Onofre Nuclear Generating Station and Adjacent Regions of Southern California: Pacific Sections AAPG, SEPM, and SEG Guide Book 46:A36-A46.

Ehret DJ, Hubbell G, and MacFadden BJ. 2009a. Exceptional preservation of the white shark Carcharodon (Lamniformes, Lamnidae) from the Early Pliocene of Peru. Journal of Vertebrate Paleontology 29:1-13.

Ehret DJ, MacFadden BJ, Jones DS, DeVries TJ, Foster DA, and Salas-Gismondi R. 2012. Origin of the white shark Carcharodon (Lamniformes: Lamnidae) based on recalibration of the upper Neogene Pisco Formation of Peru. Palaeontology 55:1139-1153.

Ehret DJ, MacFadden BJ, and Salas-Gismondi R. 2009b. Caught in the act: trophic interactions between a 4-million year old white shark (Carcharodon) and mysticete whale from Peru. Palaios 24:329-333.

Eldridge GH, and Arnold R. 1907. The Santa Clara Valley, Puente Hills, and Los Angeles oil districts, Southern California. US Geological Survey Bulletin 309:1-266.

Fedorov AV, Brierley CM, Lawrence KT, Liu Z, Dekens PS, and Ravelo AC. 2013. Patterns and mechanisms of early Pliocene warmth. Nature 496:44-49.

Ferrón HG. 2017. Regional endothermy as a trigger for gigantism in some extinct macropredatory sharks. PLoS ONE 12:e0185185.

Fitch JE. 1970. Fish remains, mostly otoliths and teeth, from the Palos Verdes Sand (late Pleistocene) of California. Los Angeles County Museum Contributions in Science 199:141.

Fitzgerald EMG. 2004. A review of the Tertiary fossil Cetacea (Mammalia) localities in Australia. Memoirs of the Museum of Victoria 61:183-208.

Fitzgerald EMG. 2005. Pliocene marine mammals from the Whalers Bluff Formation of Portland, Victoria, Australia. Memoirs of Museum Victoria 62:67-89.

Flemming C, and McFarlane DA. 1998. New Caribbean locality for the extinct great white shark Carcharodon megalodon. Caribbean Journal of Science 34:317-318.

Fordyce RE, and Muizon C de. 2001. Evolutionary history of cetaceans: a review. In: Mazin JM, and Buffrenil V de, eds. Secondary Adaptations of Tetrapods to Life in Water. Munich, Germany: Verlag Dr. Friedrich Pfeil, 169-233.

Frazzetta TH. 1988. The mechanics of cutting and the form of shark teeth (Chondrichthyes, Elasmobranchii). Zoomorphology 108:93-107.

Galloway AJ. 1977. Geology of the Point Reyes Peninsula, Marin County, California. California Division of Mines and Geology Bulletin 202:1-72.

Garcia EXM, Antunes MT, Caceras-Balbino A, Ruiz-Munoz F, and Civis-Llovera J. 2009. Los tiburones Lamniformes (Chondrichthyes, Galeomorphii) del Pliocene inferior de la Formación Arenas de Huelva, suroeste de la cuenca del Guadalquivir, España. Revista Mexicana de Ciencias Geologicas 26:674-686.

Gervais P. 1852. Zoologie et paléontologie française (animaux vertébrés). Paris: Arthus Bertrand. 
1223 Gibbard PL, Head MJ, Walker MJ, and Stratigraphy SoQ. 2009. Formal ratification of the

1224

1225

1226

1227

1228

1229

1230

1231

1232

1233

1234

1235

1236

1237

1238

1239

1240

1241

1242

1243

1244

1245

1246

1247

1248

1249

1250

1251

1252

1253

1254

1255

1256

1257

1258

1259

1260

1261

1262

1263

1264

1265

1266

1267
Quaternary System/Period and the Pleistocene Series/Epoch with a base at 2.58 Ma. Journal of Quaternary Science 25:96-102.

Gottfried MD, Compagno LJV, and Bowman SC. 1996. Size and skeletal anatomy of the giant "megatooth" shark Carcharodon megalodon. In: Klimley AP, and Ainley DG, eds. Great White Sharks: the biology of Carcharodon carcharias. San Diego: Academic Press, 5566.

Gottfried MD, and Fordyce RE. 2001. An associated specimen of Carcharodon angustidens (Chondrichthyes, Lamnidae) from the Late Oligocene of New Zealand, with comments on Carcharodon interrelationships. Journal of Vertebrate Paleontology 21:730-739.

Gradstein FM, Ogg JG, Schmitz M, and Ogg G. 2012. The Geologic Time Scale 2012. Oxford: Elsevier.

Gradstein FM, Ogg JG, Smith AG, Agterberg FP, Bleeker W, Cooper RA, Davydov V, Gibbard P, Hinnov L, House MR, Lourens L, Luterbacher HP, McArthur J, Melchin MJ, Robb LJ, Shergold J, Villeneuve M, Wardlaw BR, Ali J, Brinkhuis H, Hilgen FJ, Hooker J, Howarth RJ, Knoll AH, Laskar J, Monechi S, Powell J, Plumb KA, Raffi I, Röhl U, Sadler P, Sanfilippo A, Schmitz B, Shackleton NJ, Shields GA, Strauss H, Van Dam J, Veizer J, van Kolfschoten T, and Wilson D. 2004. A geologic timescale 2004. Cambridge: Cambridge University Press.

Grant US, IV, and Gale HR. 1931. Catalogue of the marine Pliocene and Pleistocene Mollusca of California. San Diego Society of Natural History Memoir 1:1-1036.

Hall CA. 2002. Nearshore marine paleoclimatic regions, increasing zoogeographic provinciality, molluscan extinctions, and paleoshorelines, California: Late Oligocene (27 Ma) to Late Pliocene (2.5 Ma). Geological Society of America Special Paper 357:1-489.

Hanna GD. 1926. Paleontology of Coyote Mountain, Imperial County, California. Proceedings of the California Academy of Sciences 24:427-503.

Haug GH, Tiedemann R, Zahn R, and Ravelo AC. 2001. Role of Panama uplift on oceanic freshwater balance. Geology 29:207-210.

Heyning JE, and Dahlheim ME. 1988. Orcinus orca. Mammalian Species 304:1-9.

Hilgen FJ, Lourens LJ, Van Dam JA, Beu AG, Boyes AF, Cooper RA, Krijgsman W, Ogg JG, Piller WE, and Wilson DS. 2012. The Neogene Period. In: Gradstein FM, Ogg JG, Schmitz M, and Ogg G, eds. The Geologic Time Scale 2012. Amsterdam: Elsevier, 923978.

Holt JW, Holt EW, and Stock JM. 2000. An age constraint on Gulf of California rifting from the Santa Rosalía basin, Baja California Sur, Mexico. Geological Society of America Bulletin 112:540-549.

Ingle JC. 1979. Biostratigraphy and paleoecology of early Miocene through early Pleistocene benthonic and planktonic Foraminifera, San Joaquin Hills-Newport Bay-Dana Point area, Orange County, California. In: Stuart CJ, editor. A guidebook to Miocene Lithofacies and Depositional Environments, Coastal Southern California and Northwestern Baja California: Pacific Section of Society of Economic Paleontologists and Mineralogists. p 53-77.

Iturralde-Vinent M, Hubbell G, and Rojas R. 1996. Catalogue of Cuban fossil Elasmobranchii (Paleocene to Pliocene) and paleogeographic implications of their lower to middle Miocene occurrence. The Journal of the Geological Society of Jamaica 31:7-21. 
1268 Jaramillo C, Montes C, Cardona A, Silvestro D, Antonelli A, and Bacon CD. 2017. Comment on

1269

1270

1271

1272

1273

1274

1275

1276

1277

1278

1279

1280

1281

1282

1283

1284

1285

1286

1287

1288

1289

1290

1291

1292

1293

1294

1295

1296

1297

1298

1299

1300

1301

1302

1303

1304

1305

1306

1307

1308

1309

1310

1311

1312

1313

"Formation of the Isthmus of Panama" by O'dea et al. Science Advances 3:e1602321.

Johnson ME, and Ledesma-Vasquez J. 2001. Pliocene-Pleistocene rocky shorelines trace coastal development of Bahía Concepción, gulf coast of Baja California Sur (Mexico). Palaeogeography, Palaeoclimatology, Palaeoecology 166:65-88.

Jordan DS. 1907. The fossil fishes of California, with supplementary notes on other species of extinct fishes. University of California Publications Bulletin of the Department of Geology 5:95-144.

Jordan DS. 1910. Notes on ichthyology. American Midland Naturalist 519:178-191.

Jordan DS. 1922. Some shark's teeth from the California Pliocene. The American Journal of Science, fifth series 2:338-342.

Jordan DS, and Hannibal H. 1923. Fossil sharks and rays of the Pacific slope of North America. Bulletin of the Southern California Academy of Science 22:27-63.

Kanakoff GP. 1956. Fish records from the Pleistocene of southern California. Bulletin of the Southern California Academy of Science 55:47-49.

Kemp NR. 1991. Chondrichthyans in the Cretaceous and Tertiary of Australia. In: Vickers-Rich P, Monaghan JM, Baird RF, and Rich TH, eds. Vertebrate Palaeontology of Australasia. Melbourne: Pioneer Design Studio in cooperation with the Monash University Publications Committee.

Kent BW. 1999. Speculations on the size and morphology of the extinct lamnoid shark, Parotodus benedeni (le Hon). The Mosasaur 6:11-15.

Kent BW, and Powell GW, Jr. 1999. Reconstructed dentition of the rare lamnoid shark Parotodus benedeni (le Hon) from the Yorktown Formation (Early Pliocene) at Lee Creek Mine, North Carolina. The Mosasaur 6:1-10.

Kern JP, and Wicander ER. 1974. Origin of a bathymetrically displaced marine invertebrate fauna in the upper part of the Capistrano Formation (Lower Pliocene), southern California. Journal of Paleontology 48:495-505.

Keyes IW. 1972. New records of the elasmobranch C. megalodon (Agassiz) and a review of the genus Carcharodon in the New Zealand fossil record. New Zealand Journal of Geology and Geophysics 15:228-242.

Kohno N, and Tomida Y. 1993. Marine mammal teeth (Otariidae and Delphinidae) from the early Pleistocene Setana Formation, Hokkaido, Japan. Bulletin of the National Science Museum, Tokyo 19:139-146.

Lajoie KR, Ponti DJ, Powell CL, II, Mathieson SA, and Sarna-Wojcicki AM. 1991. Emergent marine strandlines and associated sediments, coastal California: a record of Quaternary sea-level fluctuations, vertical tectonic movements, climatic changes, and coastal processes. In: Morrison RB, ed. Quaternary Geology of the Pacific Margin; Quaternary Nonglacial Geology: conterminous US (volume K-2) The Geology of North America. Boulder, CO: Geological Society of America, 190-213.

Lambert O, Bianucci G, Post K, Muizon C de, Salas-Gismondi R, Urbina M, and Reumer J. 2010. The giant bite of a new raptorial sperm whale from the Miocene epoch of Peru. Nature 466:105-108.

Lindberg DR, and Pyenson ND. 2006. Evolutionary patterns in Cetacea: fishing up prey size through deep time. In: Estes JA, DeMaster DP, Doak DP, Williams TM, and Brownell RL, eds. Whales, Whaling, and Ocean Ecosystems. Berkeley, California: University of California Press, 67-81. 
1314 Long DJ. 1993. Late Miocene and Early Pliocene fish assemblages from the north central coast

1315

1316

1317

1318

1319

1320

1321

1322

1323

1324

1325

1326

1327

1328

1329

1330

1331

1332

1333

1334

1335

1336

1337

1338

1339

1340

1341

1342

1343

1344

1345

1346

1347

1348

1349

1350

1351

1352

1353

1354

1355

1356

1357

1358 of Chile. Tertiary Research 14:117-126.

Long DJ. 1994. Historical biogeography of sharks from the eastern North Pacific Ocean Ph.D. University of California, Berkeley.

Long DJ, Boessenecker RW, and Ehret DJ. 2014. Timing of evolution in the Carcharodon lineage: Rapid morphological change creates a major shift in a predator's trophic niche. 2nd Annual Sharks International Conference. Durban, South Africa. p 123.

Longbottom AE. 1979. Miocene shark's teeth from Ecuador. Bulletin of the British Museum (Natural History) Geology 32:57-70.

Lydekker R. 1887. The Cetacea of the Suffolk Crag. Quarterly Journal of the Geological Society 43:7-18.

MacFadden BJ, Labs-Hochstein J, Quitmyer I, and Jones DS. 2004. Incremental growth and diagenesis of skeletal parts of the lamnoid shark Otodus obliquus from the early Eocene (Ypresian) of Morocco. Palaeogeography, Palaeoclimatology, Palaeoecology 206:179192.

Marsili S. 2008. Systematic, paleoecologic and paleobiogeographic analysis of the PlioPleistocene Mediterranean elasmobranch fauna. Atti Della Societa Toscana Di Scienze Naturali Memorei Serie A 113:81-88.

Marx FG, and Uhen MD. 2010. Climate, critters, and cetaceans: Cenozoic drivers of the evolution of modern whales. Science 327:993-996.

Miller KG, Kominz MA, Browning JV, Wright JD, Mountain GS, Katz ME, Sugarman PJ, Cramer BS, Christie-Blick N, and Pekar SF. 2005. The Phanerozoic record of global sealevel change. Science 310:1293-1297.

Mitchell ED. 1961. A new walrus from the imperial Pliocene of Southern California: with notes on odobenid and otariid humeri. Contributions in Science 44:1-28.

Mitchell ED. 1966. History of research at Sharktooth Hill, Kern County, California. Bakersfield, California: Kern County Historical Society.

Mitchell ED, and Repenning CA. 1963. The chronologic and geographic range of desmostylians. Contributions in Science, Natural History Museum of Los Angeles County 78:1-20.

Morgan GS. 1994. Miocene and Pliocene marine mammal faunas from the Bone Valley Formation of central Florida. Proceedings of the San Diego Society of Natural History 29:239-268.

Mount JD. 1974. Type vertebrates from Lomita, California, in the Municipal Museum, Riverside, California. Journal of Paleontology 48:198-199.

Muizon C de, and de Vries TJ. 1985. Geology and paleontology of late Cenozoic marine deposits in the Sacaco area (Peru). Geologische Rundschau 74:547-563.

Müller A. 1999. Ichthyofaunen aus dem atlantischen Tertiär der USA. Leipziger Geowissenschaften, Leipzig 9/10:1-360.

Norris RD. 1986. Taphonomic gradients in shelf fossil assemblages: Pliocene Purisima Formation, California. Palaios 1:256-270. 10.2307/3514689

Nyberg KG, Ciampaglio CN, and Wray GA. 2006. Tracing the ancestry of the great white shark, Carcharodon carcharias, using morphometric analyses of fossil teeth. Journal of Vertebrate Paleontology 26:806-814.

Obradovich JD. 1965. The potential use of glauconite for Late-Cenozoic geochronology. Proceedings of the International Association for Quaternary Research 8:267-279. 
1359 O’Dea A, Lessios HA, Coates AG, Eytan RI, Restrepo-Moreno SA, Cione AL, Collins LS, de

1360

1361

1362

1363

1364

1365

1366

1367

1368

1369

1370

1371

1372

1373

1374

1375

1376

1377

1378

1379

1380

1381

1382

1383

1384

1385

1386

1387

1388

1389

1390

1391

1392

1393

1394

1395

1396

1397

1398

1399

1400

1401

1402

1403 Queiroz A, Farris DW, Norris RD, Stallard RF, Woodburne MO, Aguilera O, Aubry MP, Berggren WA, Budd AF, Cozzuol MA, Coppard SE, Duque-Caro H, Finnegan S, Gasparini GM, Grossman EL, Johnson KG, Keigwin LD, Knowlton N, Leigh EG, Leonard-Pingel JS, Marko PB, Pyenson ND, Rachello-Dolmen PG, Soibelzon L, Todd JA, Vermeij GJ, Jackson JBC. 2016. Formation of the Isthmus of Panama. Science Advances 2:e1600883.

Owen R. 1844. Appendix to Professor Henslow's paper, consisting of a description of the fossil tympanic bones referable to four distinct species of Balaena. Proceedings of the Geological Society of London 4:283-286.

Owen R. 1870. Monograph on the British fossil Cetacea from the Red Crag. London: The Palaeontographical Society.

Parham JF, Donoghue PCJ, Bell CJ, Calway TD, Head JJ, Holroyd PA, Inoue JG, Irmis RB, Joyce WG, Ksepka DT, Patane JSL, Smith ND, Tarver JE, Tuinen Mv, Yang Z, Angielczyk KD, Greenwood JM, Hipsley CA, Jacobs L, Makovicky PJ, Muller J, Smith KT, Theodor JM, Warnock RCM, and Benton MJ. 2012. Best practices for justifiying fossil calibrations. Systematic Biology 61:346-359.

Pawellek T, Adnet S, Cappetta H, Metais E, Salem M, Brunet M, and Jaeger JJ. 2012. Discovery of an earliest Pliocene relic tropical fish fauna in a newly detected cliff section (Sabratah Basin, NW Libya). Neues Jahrbuch für Geologie und Paläontologie Abhandlungen 266:93-114.

Pimiento C, and Balk MA. 2015. Body-size trends of the extinct giant shark Carcharocles megalodon: a deep-time perspective on marine apex predators. Paleobiology 41:479-490.

Pimiento C, and Clements CF. 2014. When did Carcharocles megalodon become extinct? A new analysis of the fossil record. PLOS ONE 9:e11086.

Pimiento C, Ehret DJ, MacFadden BJ, and Hubbell G. 2010. Ancient nursery area for the extinct giant shark Megalodon from the Miocene of Panama. PLoS ONE 5:e10552.

Pimiento C, Griffin JN, Clements CF, Silvestro D, Varela S, Uhen MD, and Jaramillo C. 2017. The Pliocene marine megafauna extinction and its impact on functional diversity. Nature Ecology \& Evolution 1:1100-1106.

Pimiento C, MacFadden BJ, Clements CF, Varela S, Jaramillo C, Velez-Juarbe J, and Silliman BR. 2016. Geographical distribution patterns of Carcharocles megalodon over time reveal clues about extinction mechanisms. Journal of Biogeography 43:1645-1655.

Ponti DJ. 1989. Aminostratigraphy and chronostratigraphy of Pleistocene marine sediments, southwestern Los Angeles Basin, California Ph.D. University of Colorado.

Powell CL, II. 1988. The Miocene and Pliocene Imperial Formation of southern California and its molluscan fauna: an overview. Wester Society of Malacologists Annual Report 20:1118.

Powell CL, II. 1998. The Purisima Formation and related rocks (upper Miocene-Pliocene), greater San Francisco Bay area, central California-Review of literature and USGS collections (now housed at the Museum of Paleontology, University of California, Berkeley). United States Geological Survey Open-File Report 98-594:1-101.

Powell CL, II. 2008. Pliocene invertebrates from the Travertine Point outcrop of the Imperial Formation, Imperial County, California. US Geological Survey Scientific Investigations Report 2008-5155:1-25. 
1404 Powell CL, II, Barron JA, Sarna-Wojcicki AM, Clark JC, Perry FA, Brabb EE, and Fleck RJ.

1405

1406

1407

1408

1409

1410

1411

1412

1413

1414

1415

1416

1417

1418

1419

1420

1421

1422

1423

1424

1425

1426

1427

1428

1429

1430

1431

1432

1433

1434

1435

1436

1437

1438

1439

1440

1441

1442

1443

1444

1445

1446

1447

1448

1449

2007. Age, stratigraphy, and correlation of the late Neogene Purisima Formation, central California coast ranges. US Geological Survey Professional Paper 1740:1-32.

Powell CL, II, Stanton RJ, and Liff-Grier P. 2008. Architectonica (Gastropoda) and associated warm-water mollusks used to correlate and date scattered outcrops in the Pliocene of south and central California. The Western Society of Malacologists, Annual Report 41:36.

Powell CL, II, and Stevens D. 2000. Age and paleoenvironmental significance of megainvertebrates from the "San Pedro" Formation in the Coyote Hills, Fullerton and Buena Park, Orange County, southern California. US Geological Survey Open File Report 00319:1-83.

Price GJ, Louys J, Faith JT, Lorenzen E, and Westaway MC. 2018. Big data little help in megafauna mysteries. Nature 558:23-25.

Purdy RW. 1996. Paleoecology of fossil white sharks. In: Klimley AP, and Ainley DG, eds. Great White Sharks: The Biology of Carcharodon carcharias. San Diego: Academic press, 67-78.

Purdy RW, Schneider VP, Applegate SP, McLellan JH, Meyer RL, and Slaughter BH. 2001. The Neogene sharks, rays, and bony fishes from Lee Creek Mine, Aurora, North Carolina. Smithsonian Contributions to Paleobiology 90:71-202.

Ransom JE. 1964. Fossils in America. New York: Harper and Row.

Repenning CA, and Tedford RH. 1977. Otarioid seals of the Neogene. US Geological Survey Professional Paper 992:1-87.

Roux C, and Geistdoerfer P. 1988. Dents de requins et bulles tympaniques de cétacés: noyaux de nodules polymétalliques récoltés dans l'océan Indien. Cybium 12:129-137.

Seret B. 1987. Découverte d'une faune à Procarcharodon megalodon (Agassiz, 1835) en Nouvelle-Calédonie (Pisces, Chondrichthyes, Lamnidae). Cybium 11:389-394.

Shimada K, Chandler RM, Lam OLT, Tanaka T, and Ward DJ. 2017. A new elusive otodontid shark (Lamniformes: Otodontidae) from the lower Miocene, and comments on the taxonomy of otodontid genera, including the 'megatoothed' clade. Historical Biology 29:704-714.

Solow AR. 2005. Inferring extinction from a sighting record. Mathematical Biosciences 195: 4755

Squires RL. 2012. Late Pliocene megafossils of the Pico Formation, Newhall area, Los Angeles County, Southern California. Los Angeles County Museum Contributions in Science 520:73-93.

Takayanagi H, Nakayama Y, Ishikawa T, Nagaishi K, and Iryu Y. 2010. Sr isotope composition of island-surface dolomites at Kita-daito-jima, northern Philippine Sea. Journal of the Geological Society of Japan 116:237-240.

Tedford RH, Albright LB, III,, Barnosky AD, Ferrusquia-Villafranca H, R.M. Jr., Swisher CC, III,, Voorhies MR, Webb SD, and Whistler DP. 2004. Mammalian biochronology of the Arikareean through Hemphillian interval (Late Oligocene through Early Pliocene epochs). In: Woodburne MO, ed. Late Cretaceous and Cenozoic Mammals of North America: Biostratigraphy and Geochronology. New York: Columbia University Press, 169-231.

Tschernezky W. 1959. Age of Carcharodon megalodon? Nature 184:1331-1332.

Vedder JG. 1972. Review of stratigraphic names and megafaunal correlation of Pliocene rocks along the southeast margin of the Los Angeles basin, California. In: Stinemeyer EH, ed.

Peer) reviewing PDF | (2018:02:25410:2:1:NEW 3 Nov 2018) 
1450

1451

1452

1453

1454

1455

1456

1457

1458

1459

1460

1461

1462

1463

1464

1465

1466

1467

1468

1469

1470

1471

1472

1473

1474

1475

1476

1477

1478

1479

1480

1481

1482

1483

1484

1485

1486

1487

1488

1489

1490

1491

1492

1493

1494

Proceedings of the Pacific Coast Miocene Biostratigraphic Symposium. Los Angeles, California: Society of Economic Paleontologists and Mineralogists, Pacific Section, 158172.

Vedder JG, Yerkes RF, and Schoellhamer JE. 1957. Geologic map of the San Joaquin Hills-San Juan Capistrano area, Orange County, California. US Geological Survey Oil and Gas Investigation Map.

Vendrasco MJ, Eernisse DJ, Powell CL, II, and Fernandez CZ. 2012. Polyplacophora (Mollusca) from the San Diego Formation: a remarkable assemblage of fossil chitons from the Pliocene of Southern California. Los Angeles County Museum Contributions in Science 520:15-72.

Wagner HM, Riney BO, Deméré TA, and Prothero DR. 2001. Magnetic stratigraphy and land mammal biochronology of a nonmarine facies of the Pliocene San Diego Formation, San Diego County, California. SEPM Pacific Section Book 91:359-368.

Walsh SA, and Hume JP. 2001. A new Neogene marine avian assemblage from north-central Chile. Journal of Vertebrate Paleontology 21:484-491.

Walsh SA, and Naish D. 2002. Fossil seals from late Neogene deposits in South America: a new pinniped (Carnivora, Mammalia) assemblage from Chile. Palaeontology 45:821-842.

Wang SC, and Marshall CR. 2016. Estimating times of extinction in the fossil record. Biology Letters 12:20150989.

Wara MW, Ravelo AC, and Delaney ML. 2005. Permanent El Nino-like conditions during the Pliocene warm period. Science 309:758-761.

Ward DJ, and Bonavia CG. 2001. Additions to, and a review of, the Miocene shark and ray fauna of Malta. Central Mediterranean Naturalist 3:131-146.

Ward LW. 2008. Synthesis of paleontological and stratigraphic investigations at the Lee Creek Mine, Aurora, N.C. Virginia Museum of Natural History Special Publication 14:325-436.

Warheit KI. 1992. A review of the fossil seabirds from the Tertiary of the north Pacific: plate tectonics, paleoceanography, and faunal change. Paleobiology 18:401-424.

Welton BJ. 1979. Late Cretaceous and Cenozoic Squalomorphii of the Northwest Pacific Ocean Ph.D. University of California.

Whitmore FC. 1994. Neogene climatic change and the emergence of the modern whale fauna of the North Atlantic Ocean. Proceedings of the San Diego Society of Natural History 29:223-227.

Whitmore FC, and Barnes LG. 2008. The Herpetocetinae, a new subfamily of extinct baleen whales (Mammalia, Cetacea, Cetotheriidae). Virginia Museum of Natural History Special Publication 14:141-180.

Wilson EC. 1985. The spiral trace fossil Gyrolithes de Saporta, 1884 in the Pliocene Tirabuzon Formation near Santa Rosalia, Baja California Sur, Mexico. Bulletin of the Southern California Academy of Science 84:57-66.

Wilson EC, and Bing DE. 1970. Type specimens of fossil Invertebrata in the Los Angeles County Museum of Natural History, exclusive of Paleoentomology. Los Angeles County Museum Contributions in Science 181:1-20.

Winker CD, and Kidwell SM. 1996. Stratigraphy of a marine rift basin: Neogene of the western Salton Trough, California. Pacific Section SEPM Book 80:295-336.

Woodring WP, Bramlette MN, and Kew WSW. 1946. Geology and Paleontology of Palos Verdes Hills, California. US Geological Survey Professional Paper 207:1-145. 
1495 Yabe H, Goto M, and Kaneko N. 2004. Age of Carcharocles megalodon: a review of the

Figure 1. Map of California (USA) and Baja California (Mexico) showing autochthonous and

parautochthonous late Miocene and Early Pliocene records of Otodus megalodon, and

allochthonous Late Pliocene and Pleistocene records.

1517 Figure 2. Teeth of Otodus megalodon from the Capistrano Formation. SDNHM 53167 in lingual in lingual (I) and labial (J) view.

1522 Figure 3. Teeth of Otodus megalodon from the Fernando Formation. LACM 148312 in lingual

1523 (A) and labial (B) view; LACM 148311 in lingual (A) and labial (B) view.

1525 Figure 4. Tooth of Otodus megalodon from the Niguel Formation. LACM 59065 in lingual (A) and labial (B) view. 
1528 Figure 5. Tooth of Otodus megalodon from the Purisima Formation. UCMP 219502 in lingual

1529 (A) and labial (B) view.

1530

1531 Figure 6. Teeth of Otodus megalodon from the San Diego Formation. SDNHM 29742 in lingual

1532 (A) and labial (B) view; LACM 156334 in lingual (C) and labial (D) view; LACM 10152 in

1533 lingual (E) and labial (F) view; LACM 103448 in lingual (G) and labial (H) view.

1535 Figure 7. Teeth of Otodus megalodon from the San Mateo Formation. LACM 131149 in lingual

1536 (A) and labial (B) view; SDNHM 24448 in lingual (C) and labial (D) view; SDNHM 23959 in

1537 lingual (E) and labial (F) view; SDNHM 77343 in lingual (G) and labial (H) view; SDNHM

153823959 in lingual (I) and labial (J) view; SDNHM 23959 in lingual (K) and labial (L) view;

1539 SDNHM 23959 in lingual (M) and labial (N) view.

1540

1541 Figure 8. Teeth of Otodus megalodon from the Tirabuzón Formation. LACM 29067 in lingual

1542 (A) and labial (B) view; LACM 29064 in lingual (C) and labial (D) view; LACM 29077 in

1543 lingual (E) and labial (F) view; LACM 29076 in lingual (G) and labial (H) view; LACM 29065

1544 in lingual (I) and labial (J) view; LACM 29074 in lingual (K) and labial (L) view; LACM 29069

1545 in lingual (M) and labial (N) view; LACM 29073 in lingual (O) and labial (P) view; LACM

154629075 in lingual (Q) and labial (R) view; LACM 29072 in lingual (S) and labial (T) view.

1548 Figure 9. Inferred dates of extinction for Otodus megalodon using the Optimal Linear Estimation

1549 (OLE) model. Data binned by 10,000 year increments. The histogram (blue) represents the \% 
1550 frequency of a given date that was estimated for the extinction out of 10,000 simulations. The

1551 curve (orange) represents increasing cumulative probability that $O$. megalodon was extinct at the 1552 given date.

1553

1554 Figure 10. Teeth of Otodus megalodon of purported Pleistocene age. LACM 159028 in lingual

1555 (A) and labial (B) view, supposedly from Palos Verdes Sand; LACM 10141 in lingual (C) and

1556 labial (D) view, supposedly from unnamed Pleistocene strata at Newport Bay Mesa.

1559 Figure 11. Geochronologic age range of Otodus megalodon-bearing strata and occurrences in the

1560 eastern North Pacific. Age control of latest Miocene and Pliocene O. megalodon-bearing

1561 stratigraphic units represented by thick vertical gray bars. Geochronologic control of $O$.

1562 megalodon occurrences depicted as thin vertical black bars. Autochthonous and

1563 parautochthonous records in blue; allochthonous (reworked) occurrences in red. Abbreviations:

1564 NALMA, North American Land Mammal Age.ío 
Figure 1

Map of California and Baja California showing genuine late Miocene and Early Pliocene records of Otodus megalodon, and dubious Late Pliocene and Pleistocene records.

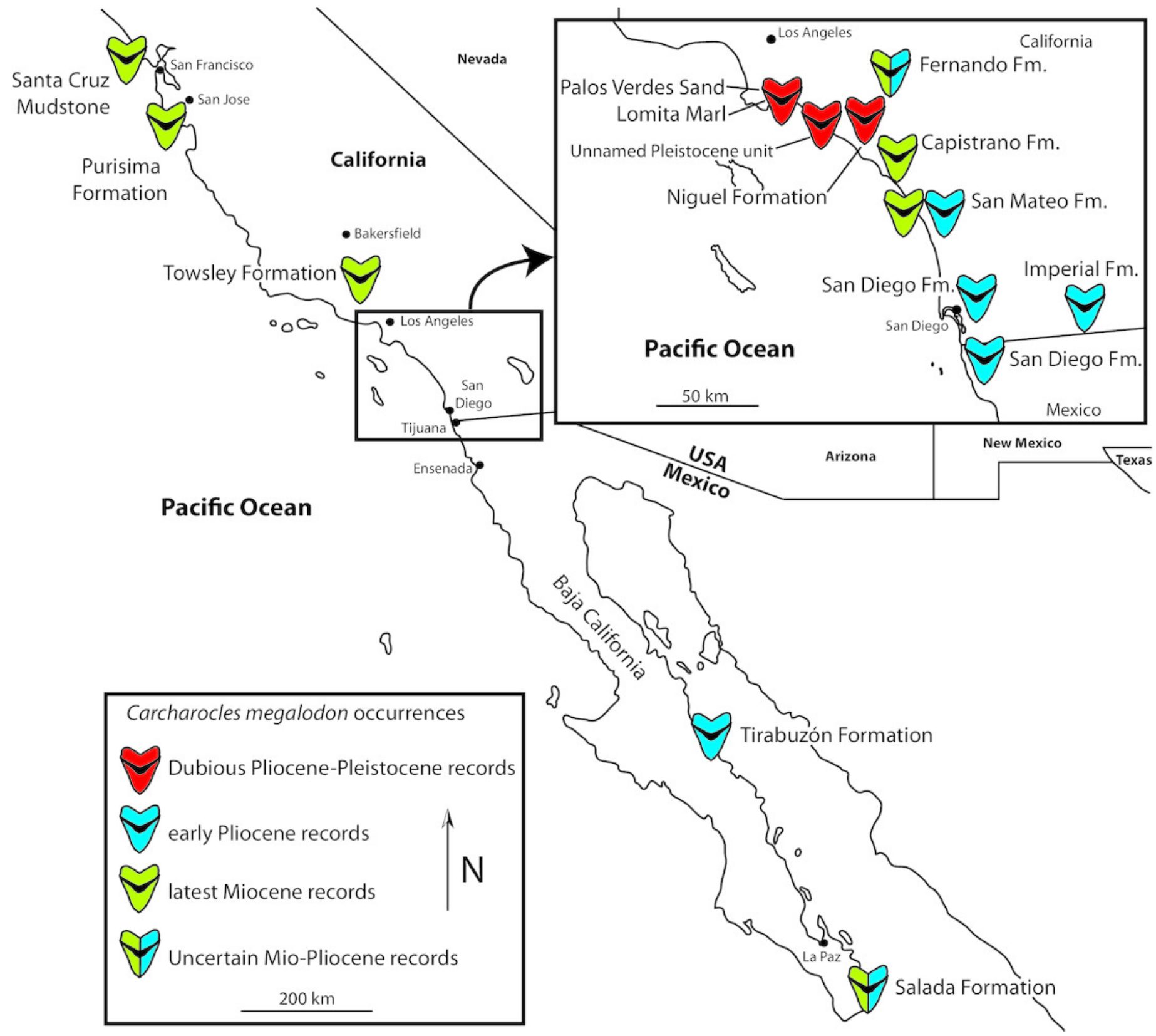




\section{Figure 2}

Otodus megalodon teeth from the Capistrano Formation.

SDNHM 53167 in lingual (a) and labial (b) view; LACM 129982 in lingual (c) and labial (d) view; LACM 59837 in lingual (e) and labial (f) view; LACM 115989 in lingual (g) and labial (h) view; LACM 59836 in lingual (i) and labial (j) view.

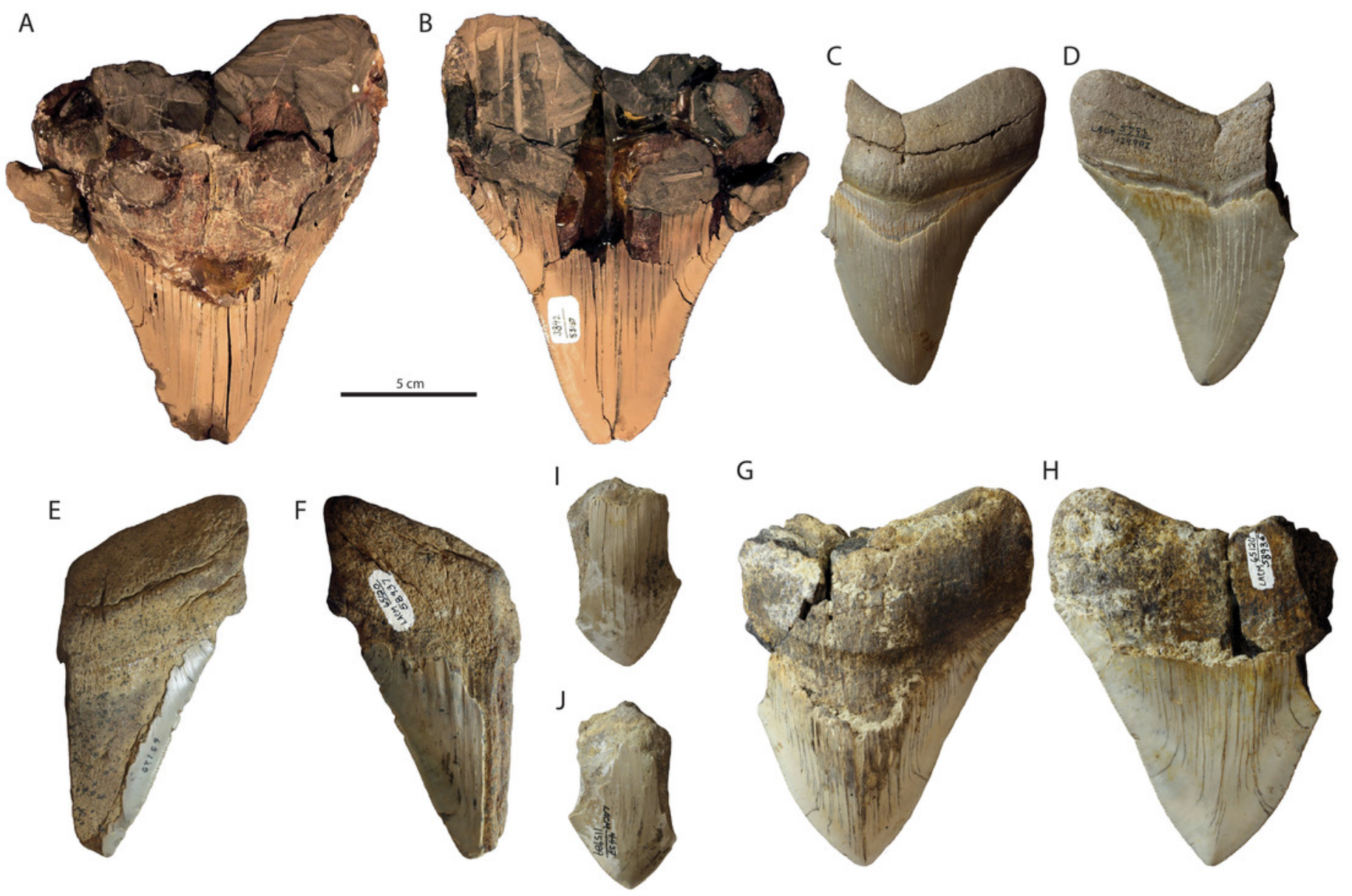


Figure 3

Otodus megalodon teeth from the Fernando Formation.

LACM 148312 in lingual (a) and labial (b) view; LACM 148311 in lingual (a) and labial (b) view. 

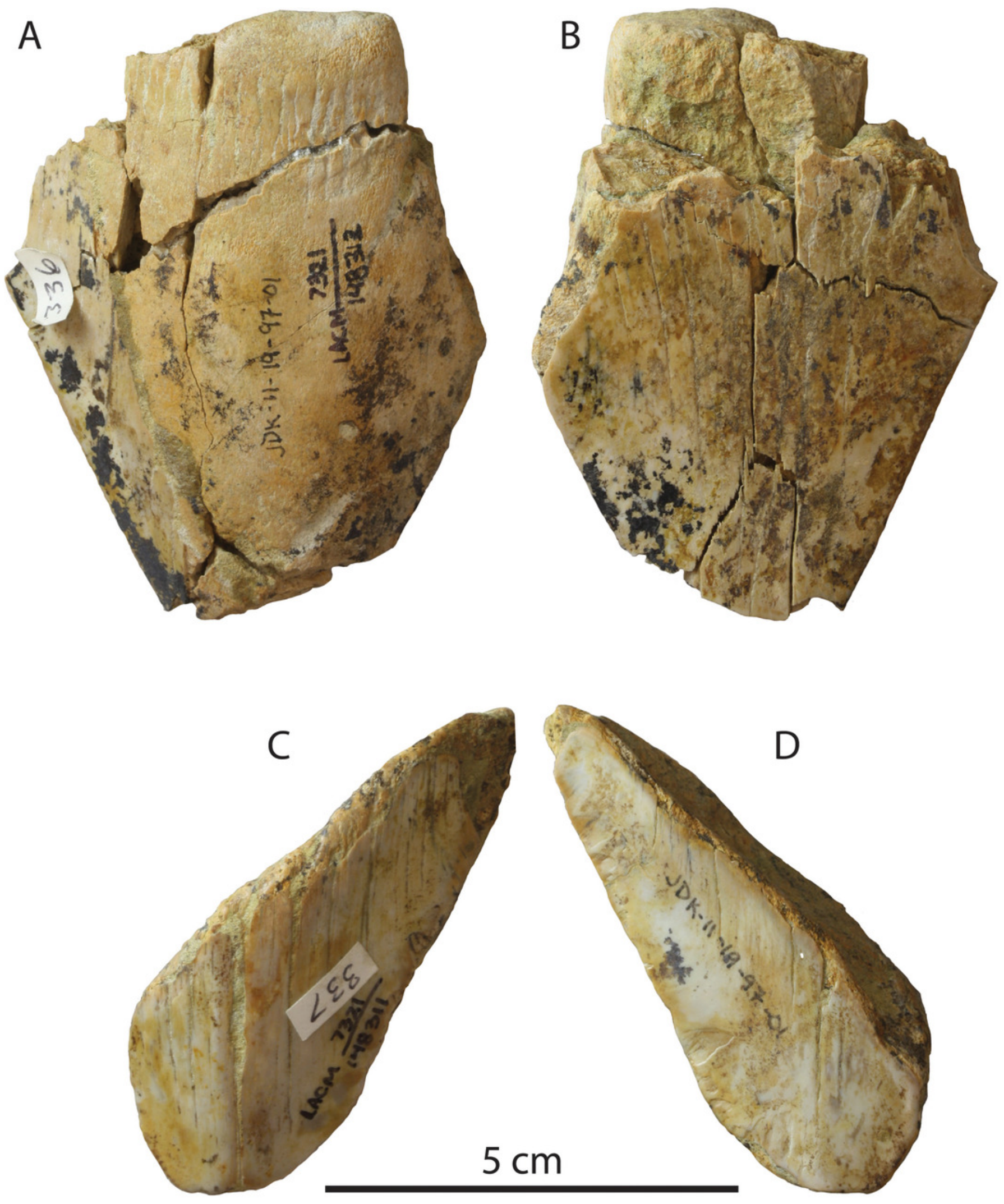
Figure 4

Otodus megalodon tooth from the Niguel Formation.

LACM 59065 in lingual (a) and labial (b) view.

A

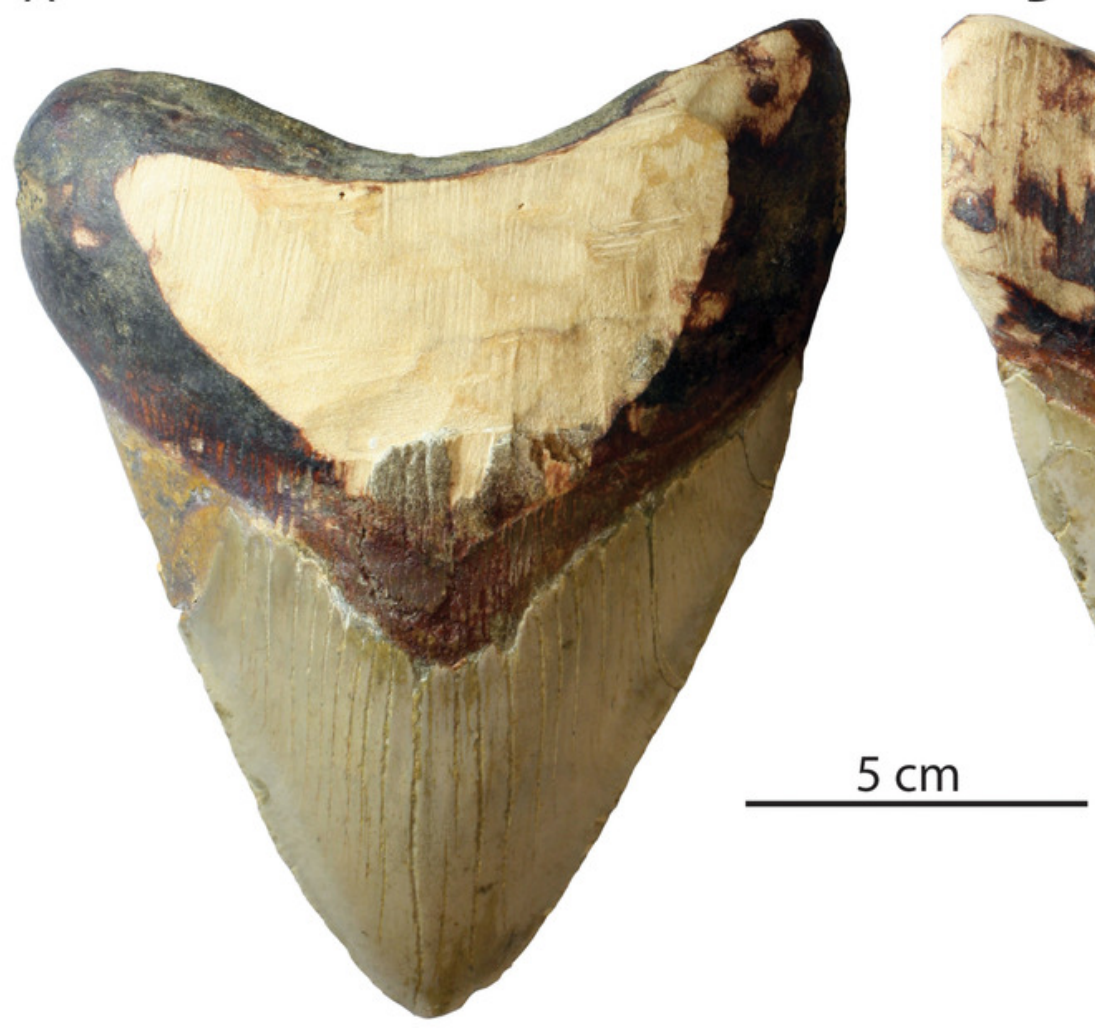

B

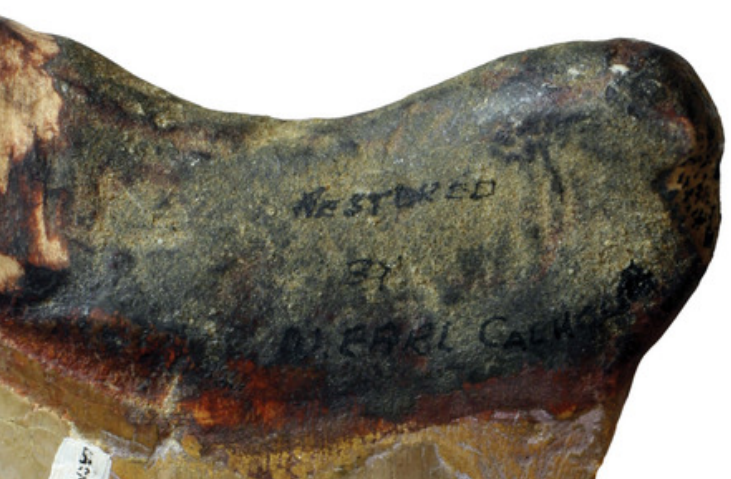


Figure 5

Otodus megalodon tooth from the Purisima Formation.

UCMP 219502 in lingual (a) and labial (b) view. 

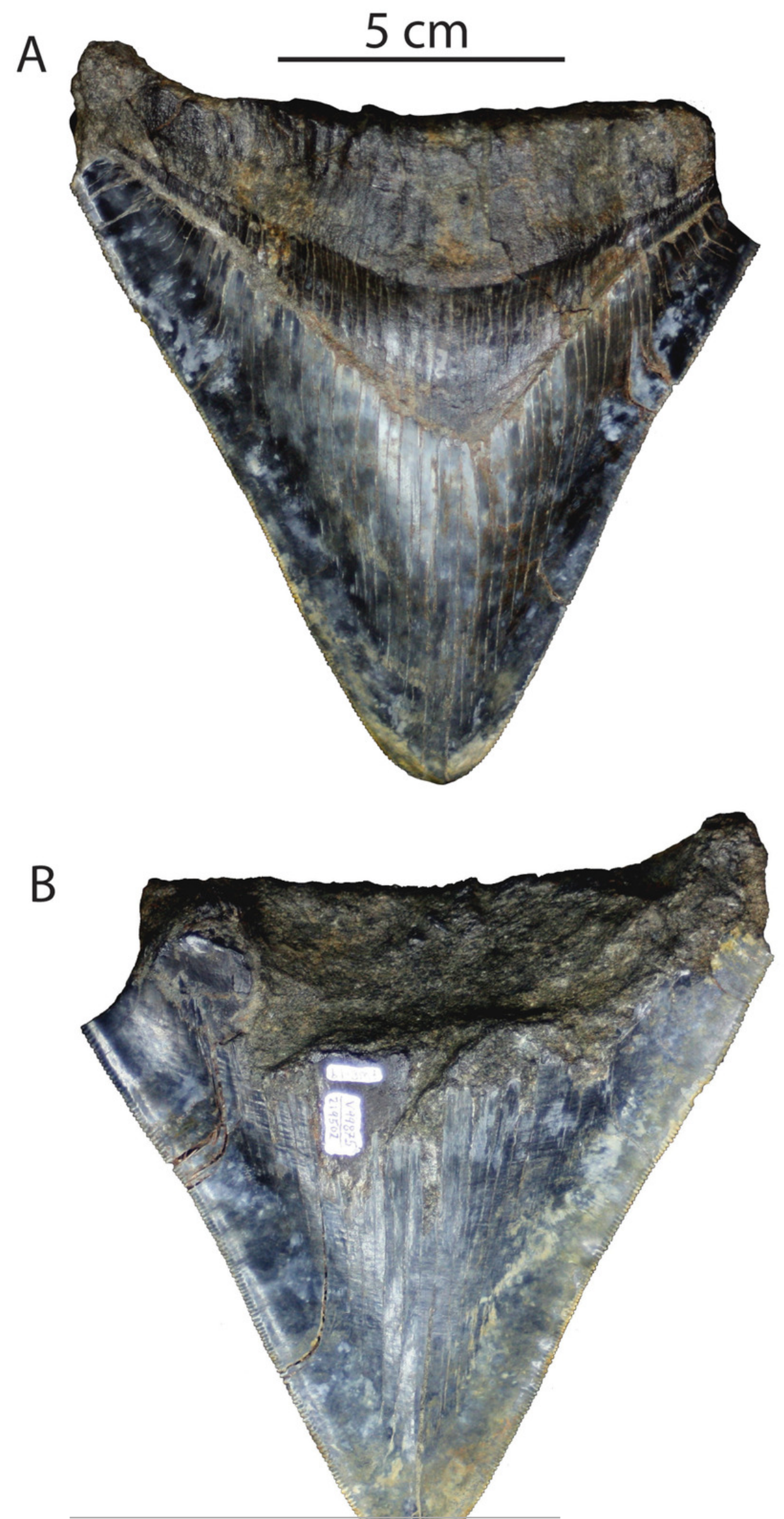


\section{Figure 6}

Otodus megalodon teeth from the San Diego Formation.

SDNHM 29742 in lingual (a) and labial (b) view; LACM 156334 in lingual (c) and labial (d) view; LACM 10152 in lingual (e) and labial (f) view; LACM 103448 in lingual (g) and labial (h) view. 

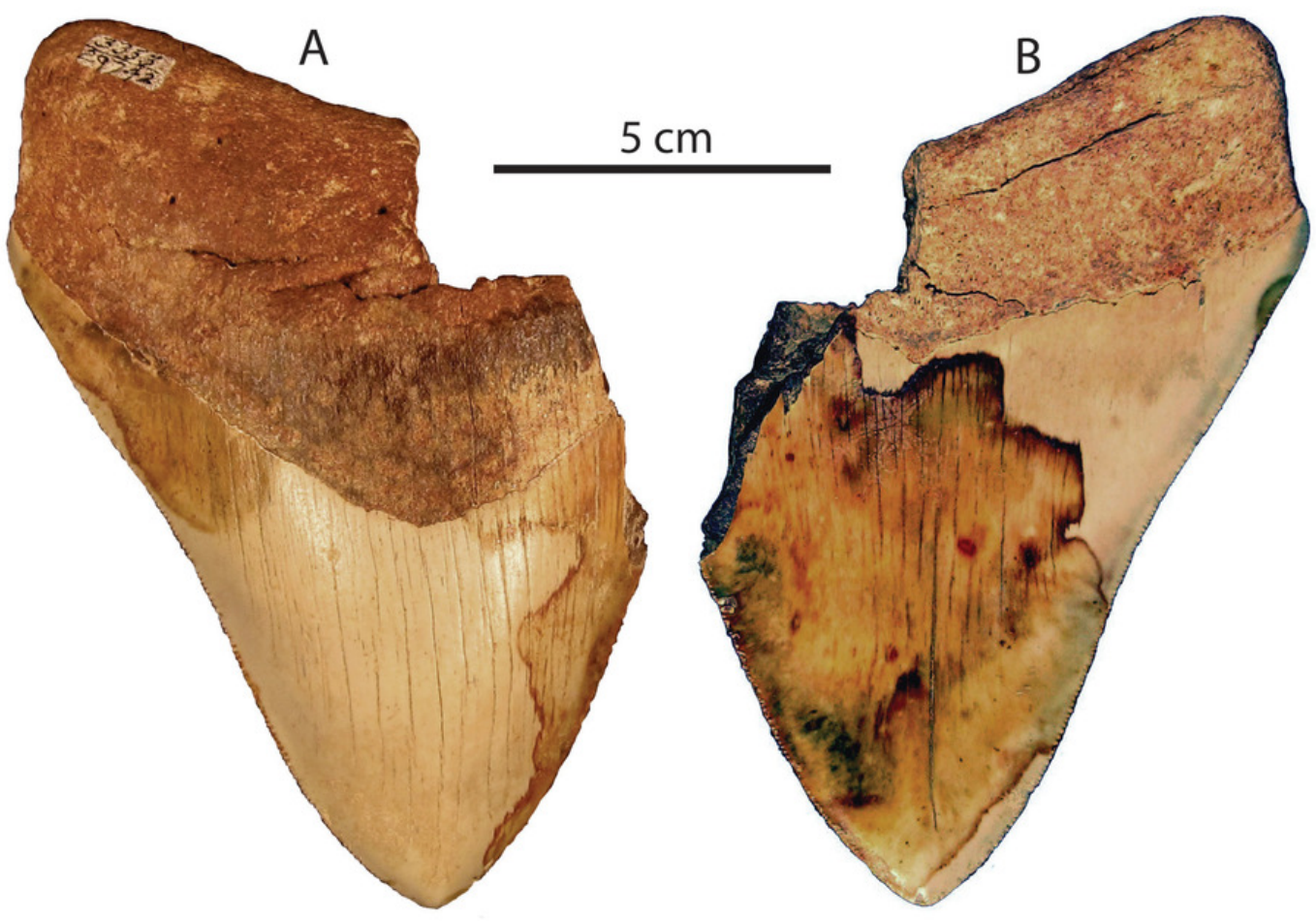

C
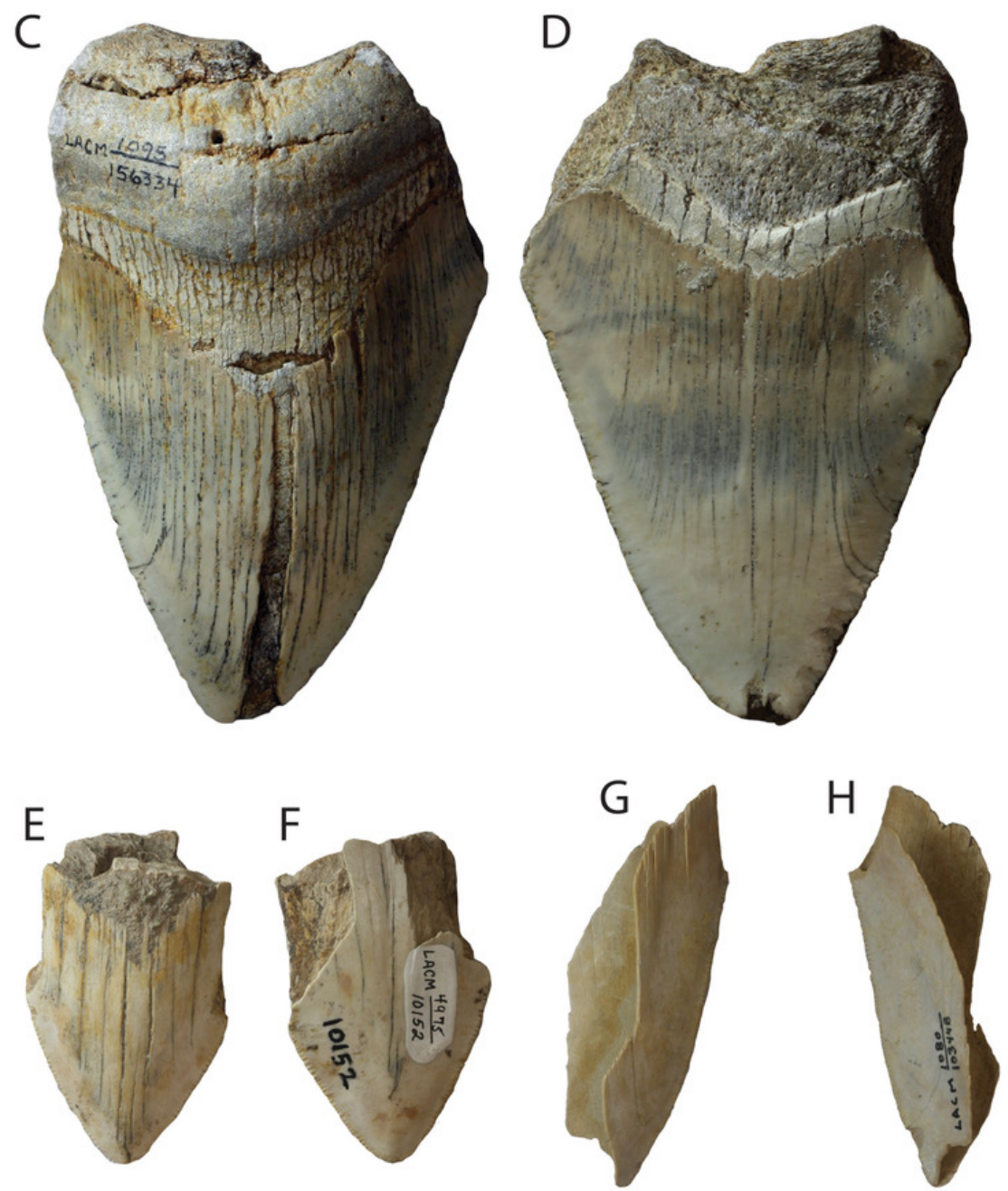


\section{Figure 7}

Otodus megalodon teeth from the San Mateo Formation.

LACM 131149 in lingual (a) and labial (b) view; SDNHM 24448 in lingual (c) and labial (d) view; SDNHM 23959 in lingual (e) and labial (f) view; SDNHM 77343 in lingual (g) and labial (h) view; SDNHM 23959 in lingual (i) and labial (j) view; SDNHM 23959 in lingual (k) and labial (I) view; SDNHM 23959 in lingual (m) and labial (n) view. 

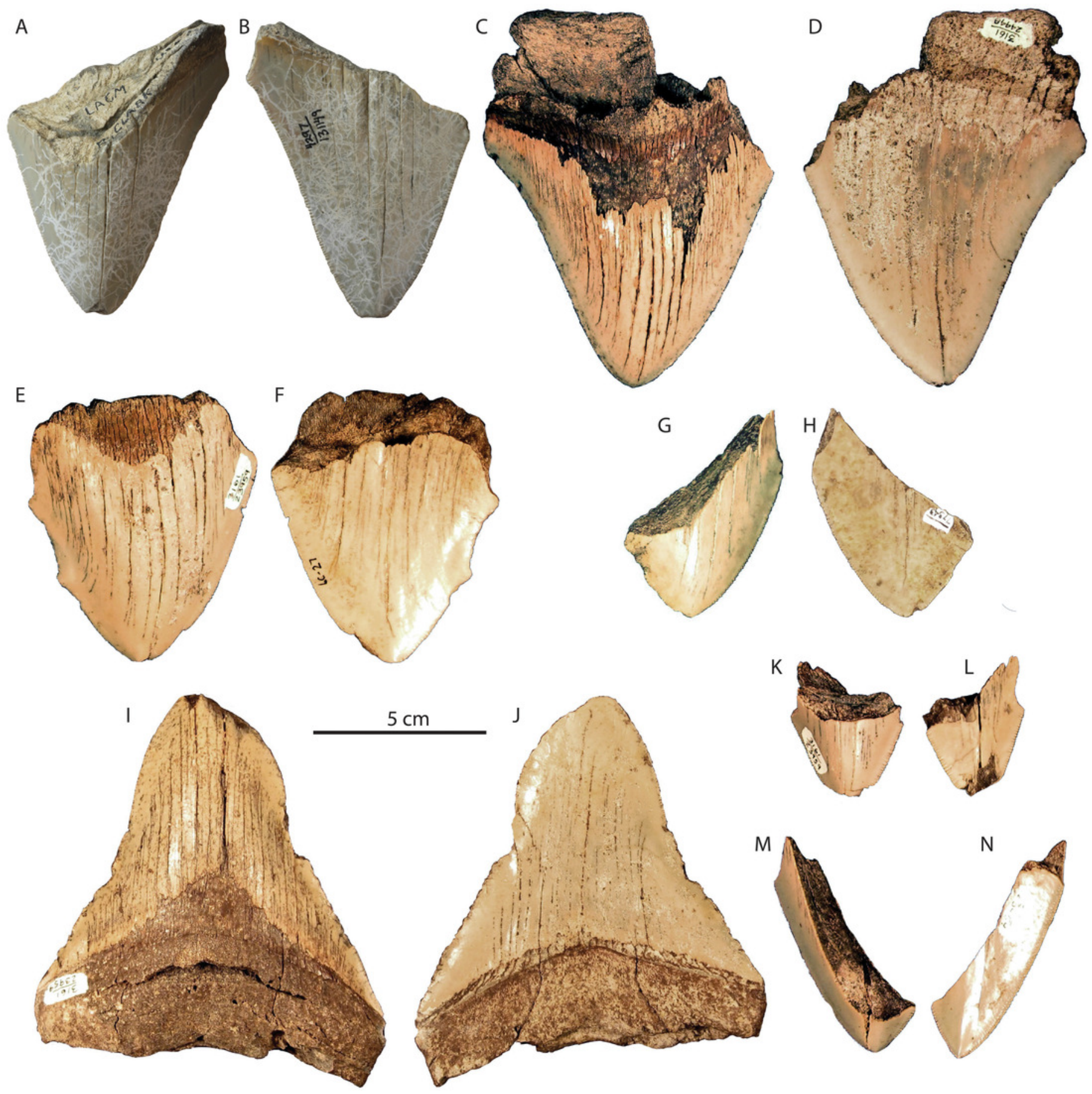


\section{Figure 8}

Otodus megalodon teeth from the Tirabuzón Formation.

LACM 29067 in lingual (a) and labial (b) view; LACM 29064 in lingual (c) and labial (d) view; LACM 29077 in lingual (e) and labial (f) view; LACM 29076 in lingual (g) and labial (h) view; LACM 29065 in lingual (i) and labial (j) view; LACM 29074 in lingual (k) and labial (I) view; LACM 29069 in lingual (m) and labial (n) view; LACM 29073 in lingual (o and labial (p) view; LACM 29075 in lingual (q) and labial (r) view; LACM 29072 in lingual (s) and labial (t) view.
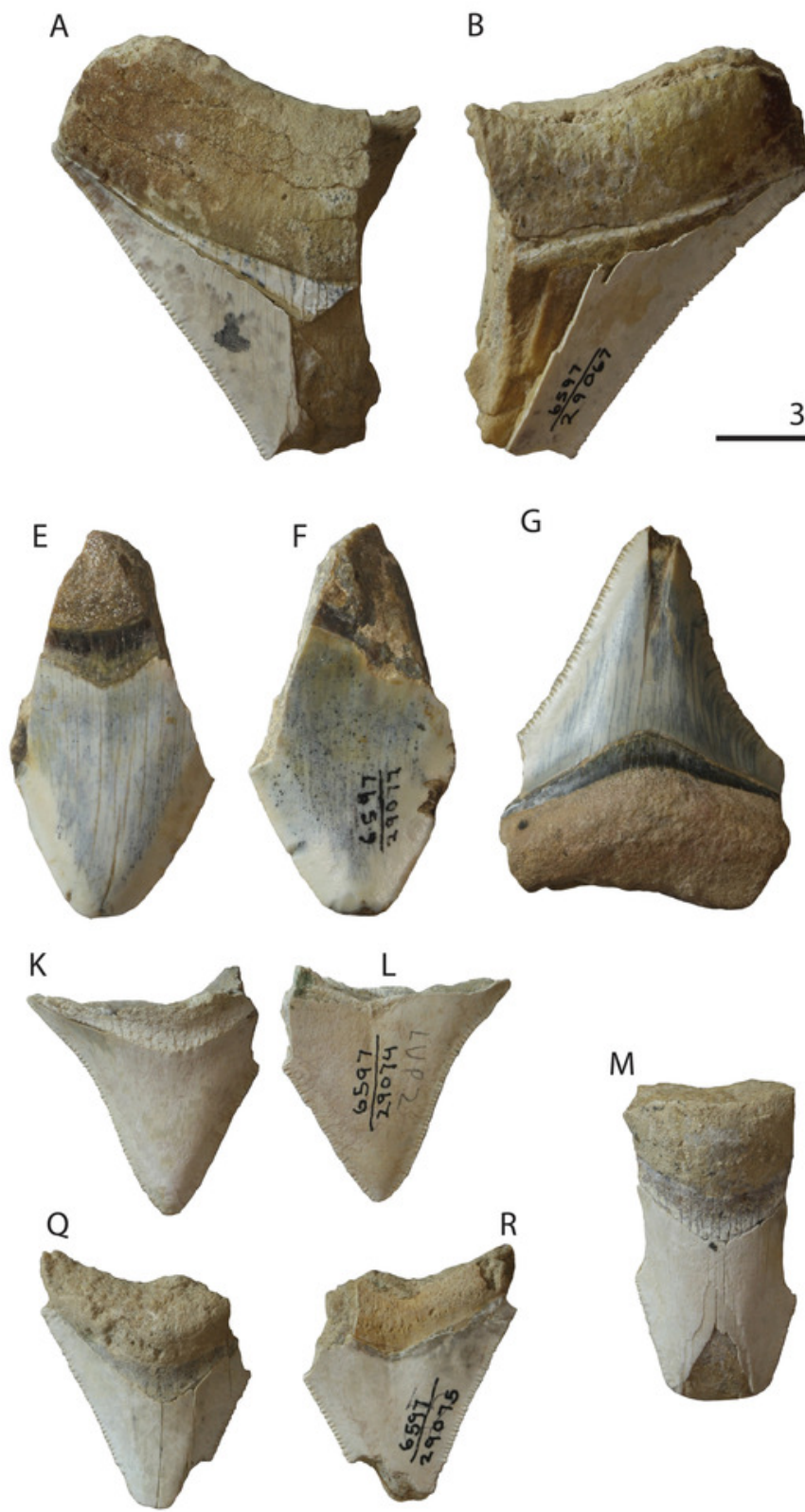

$3 \mathrm{~cm}$
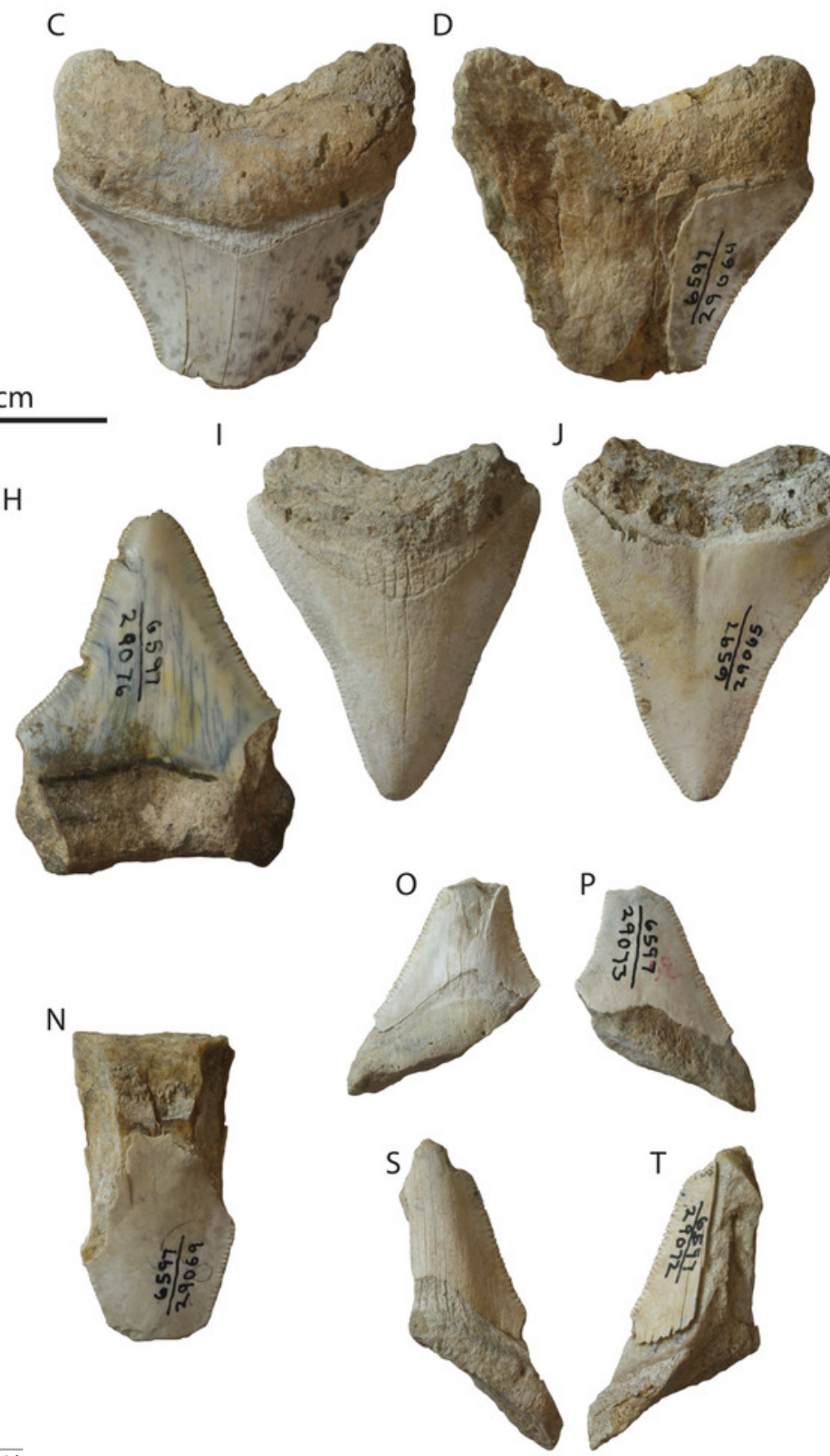
Figure 9

Inferred dates of extinction for Otodus megalodon using the Optimal Linear Estimation (OLE) model.

Data binned by 10,000 year increments. The histogram (blue) represents the $\%$ frequency of a given date that was estimated for the extinction out of 10,000 simulations. The curve (orange) represents increasing cumulative probability that $O$. megalodon was extinct at the given date.

$0 \times 9^{2} 910008010000610002000$

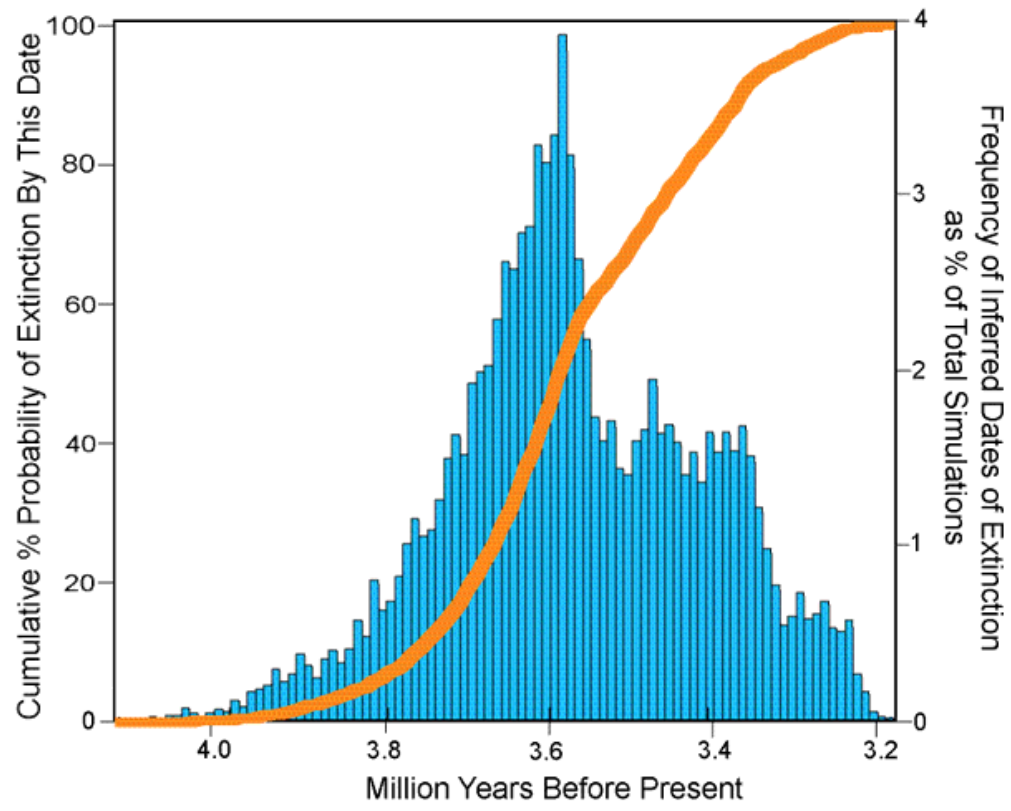




\section{Figure 10}

Otodus megalodon teeth of purported Pleistocene age.

LACM 159028 in lingual (a) and labial (b) view, supposedly from Palos Verdes Sand; LACM 10141 in lingual (c) and labial (d) view, supposedly from unnamed strata at Newport Bay Mesa.

A

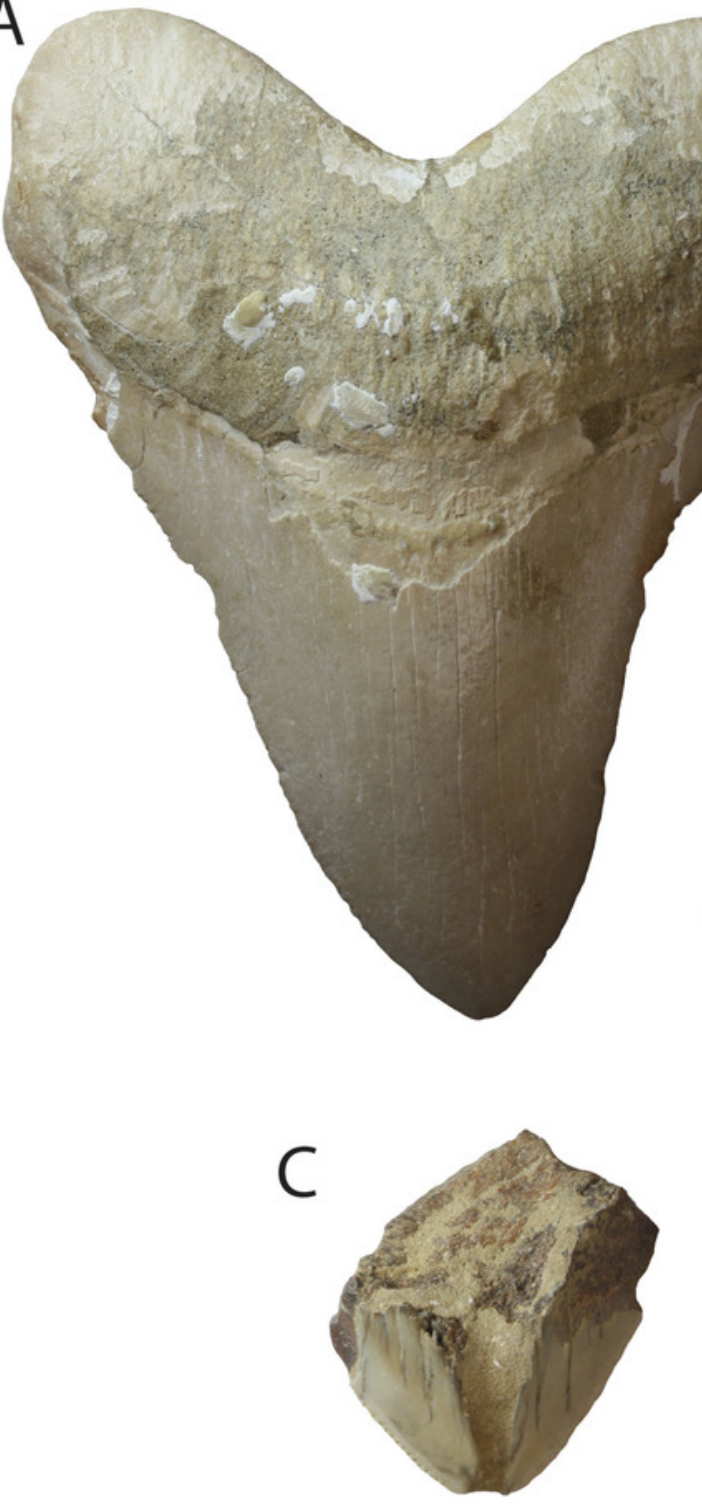

B

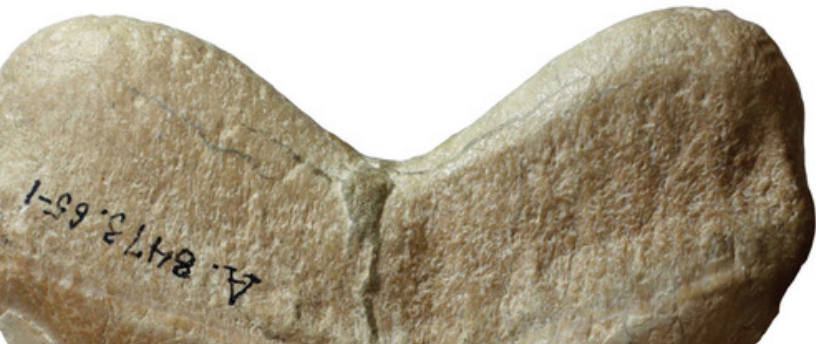

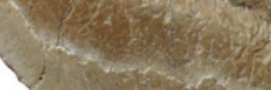

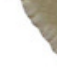
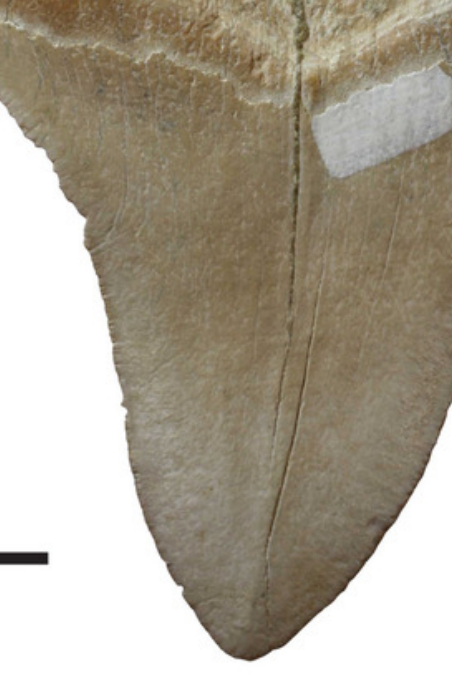

D

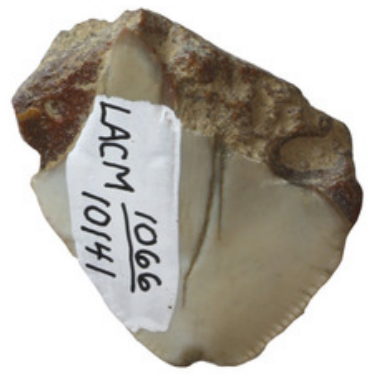


Figure 11

Geochronologic age range of Otodus megalodon-bearing strata and occurrences in the eastern North Pacific.

Age control of latest Miocene and Pliocene O. megalodon-bearing stratigraphic units represented by thick vertical gray bars. Stratigraphic range of autochthonous and parautochthonous Otodus megalodon occurrences (allochthonous records excluded) depicted as thin vertical black bars. Abbreviations: NALMA, North American Land Mammal Age.

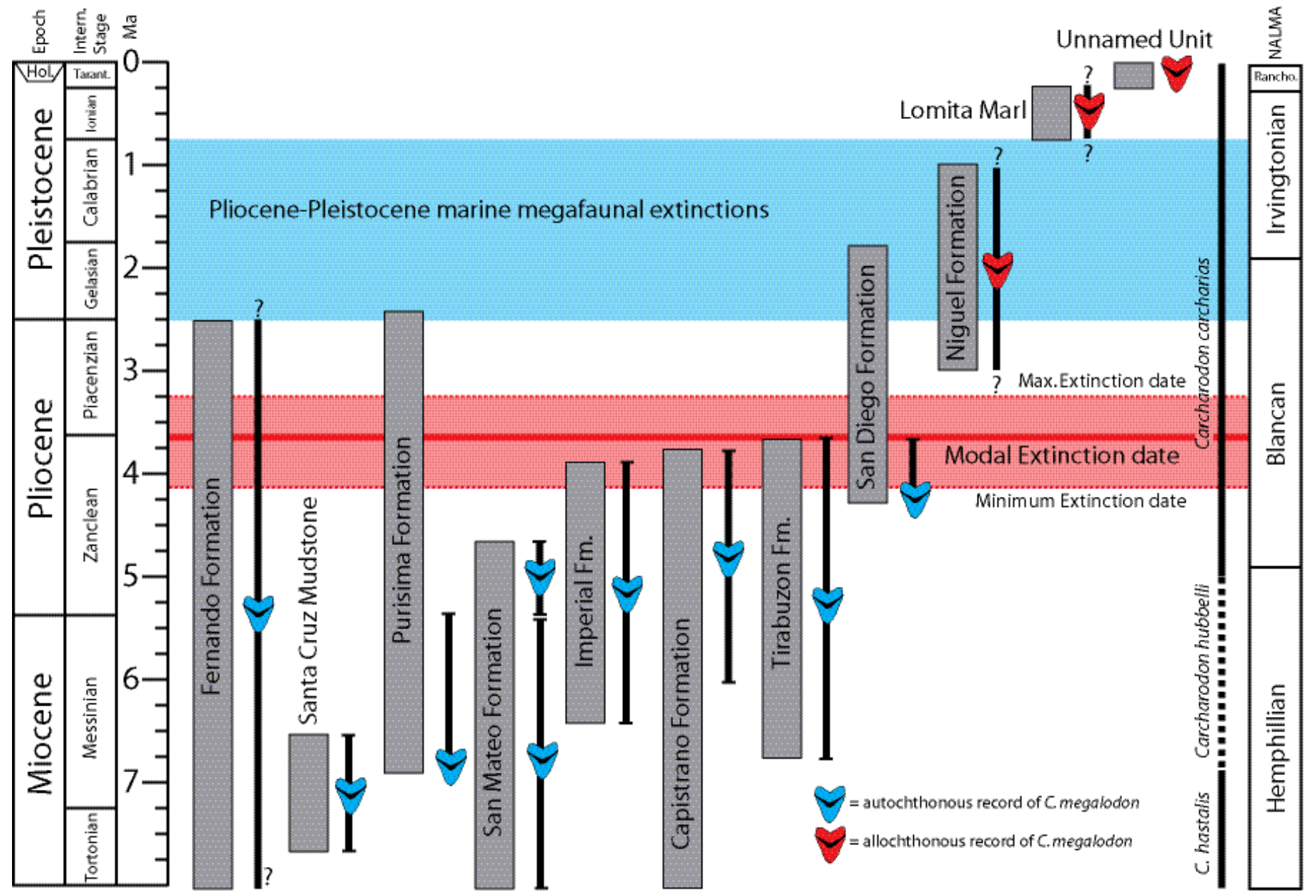




\section{Table $\mathbf{1}$ (on next page)}

Measurements (in $\mathrm{mm}$ ), age, and occurrence of Otodus megalodon teeth examined during this study.

Measurements after Pimiento et al. (2010). Asterisks $\left(^{*}\right)$ denote incomplete measurements; specimens without measurements are incomplete tooth fragments. Note that SDMHN 23959 consists of four partial teeth; a measurement is provided for the only tooth complete enough to measure. 
1 Table 1. Measurements (in mm), age, and occurrence of Otodus megalodon teeth examined

2 during this study. Measurements after Pimiento et al. (2010). Asterisks (*) denote incomplete

3 measurements; specimens without measurements are incomplete tooth fragments. Note that

4 SDMHN 23959 consists of four partial teeth; a measurement is provided for the only tooth

5 complete enough to measure.

\begin{tabular}{|c|c|c|c|c|c|}
\hline Specimen & Formation & Age & Occurrence & Crown width & $\begin{array}{l}\text { Crown } \\
\text { height }\end{array}$ \\
\hline LACM 29064 & $\begin{array}{l}\text { Tirabuzón } \\
\text { Fm. }\end{array}$ & $\begin{array}{l}\text { Zanclean, } \\
5.33-3.6 \\
\mathrm{Ma}\end{array}$ & Autochthonous & 48.55 & - \\
\hline LACM 29065 & $\begin{array}{l}\text { Tirabuzón } \\
\text { Fm. }\end{array}$ & $\begin{array}{l}\text { Zanclean, } \\
5.33-3.6 \\
\mathrm{Ma}\end{array}$ & Autochthonous & 42.9 & 45.1 \\
\hline LACM 29066 & $\begin{array}{l}\text { Tirabuzón } \\
\text { Fm. }\end{array}$ & $\begin{array}{l}\text { Zanclean, } \\
5.33-3.6 \\
\mathrm{Ma} \\
\end{array}$ & Autochthonous & - & - \\
\hline LACM 29067 & $\begin{array}{l}\text { Tirabuzón } \\
\text { Fm. }\end{array}$ & $\begin{array}{l}\text { Zanclean, } \\
5.33-3.6 \\
\mathrm{Ma}\end{array}$ & Autochthonous & - & - \\
\hline LACM 29069 & $\begin{array}{l}\text { Tirabuzón } \\
\text { Fm. }\end{array}$ & $\begin{array}{l}\text { Zanclean, } \\
5.33-3.6 \\
\mathrm{Ma}\end{array}$ & Autochthonous & - & - \\
\hline LACM 29070 & $\begin{array}{l}\text { Tirabuzón } \\
\text { Fm. }\end{array}$ & $\begin{array}{l}\text { Zanclean, } \\
5.33-3.6 \\
\mathrm{Ma}\end{array}$ & Autochthonous & - & - \\
\hline LACM 29071 & $\begin{array}{l}\text { Tirabuzón } \\
\text { Fm. }\end{array}$ & $\begin{array}{l}\text { Zanclean, } \\
5.33-3.6 \\
\mathrm{Ma}\end{array}$ & Autochthonous & - & - \\
\hline LACM 29072 & $\begin{array}{l}\text { Tirabuzón } \\
\text { Fm. }\end{array}$ & $\begin{array}{l}\text { Zanclean, } \\
5.33-3.6 \\
\mathrm{Ma}\end{array}$ & Autochthonous & - & - \\
\hline LACM 29073 & $\begin{array}{l}\text { Tirabuzón } \\
\text { Fm. }\end{array}$ & $\begin{array}{l}\text { Zanclean, } \\
5.33-3.6 \\
\mathrm{Ma}\end{array}$ & Autochthonous & $22.3 *$ & $18.15^{*}$ \\
\hline LACM 29074 & $\begin{array}{l}\text { Tirabuzón } \\
\text { Fm. }\end{array}$ & $\begin{array}{l}\text { Zanclean, } \\
5.33-3.6 \\
\mathrm{Ma} \\
\end{array}$ & Autochthonous & 31.7 & 32.45 \\
\hline LACM 29075 & $\begin{array}{l}\text { Tirabuzón } \\
\text { Fm. }\end{array}$ & $\begin{array}{l}\text { Zanclean, } \\
5.33-3.6 \\
\mathrm{Ma} \\
\end{array}$ & Autochthonous & $28.3^{*}$ & $29.5^{*}$ \\
\hline LACM 29076 & Tirabuzón & Zanclean, & Autochthonous & 33.4 & 36.75 \\
\hline
\end{tabular}




\begin{tabular}{|c|c|c|c|c|c|}
\hline & Fm. & $\begin{array}{l}5.33-3.6 \\
\mathrm{Ma}\end{array}$ & & & \\
\hline LACM 29077 & $\begin{array}{l}\text { Tirabuzón } \\
\text { Fm. }\end{array}$ & $\begin{array}{l}\text { Zanclean, } \\
5.33-3.6 \\
\mathrm{Ma}\end{array}$ & Autochthonous & - & - \\
\hline LACM 29078 & $\begin{array}{l}\text { Tirabuzón } \\
\text { Fm. }\end{array}$ & $\begin{array}{l}\text { Zanclean, } \\
5.33-3.6 \\
\mathrm{Ma}\end{array}$ & Autochthonous & - & - \\
\hline LACM 10141 & $\begin{array}{l}\text { "Palos } \\
\text { Verdes" Ss. }\end{array}$ & Pleistocene & Poor provenance & - & - \\
\hline LACM 10152 & $\begin{array}{l}\text { San Diego } \\
\text { Fm. }\end{array}$ & Pliocene & Autochthonous & - & - \\
\hline LACM 103448 & $\begin{array}{l}\text { San Diego } \\
\text { Fm. }\end{array}$ & Pliocene & Autochthonous & - & - \\
\hline LACM 115989 & $\begin{array}{l}\text { Capistrano } \\
\text { Fm. }\end{array}$ & $\begin{array}{l}\text { Messinian- } \\
\text { Zanclean, } \\
\text { 5.6-3.7 Ma }\end{array}$ & Autochthonous & - & - \\
\hline LACM 129982 & $\begin{array}{l}\text { Capistrano } \\
\text { Fm. }\end{array}$ & $\begin{array}{l}\text { Messinian- } \\
\text { Zanclean }\end{array}$ & Autochthonous & - & - \\
\hline LACM 131149 & $\begin{array}{l}\text { San Mateo } \\
\text { Fm. }\end{array}$ & $\begin{array}{l}\text { Zanclean, } \\
5.33-4.6 \\
\mathrm{Ma}\end{array}$ & $\begin{array}{l}\text { Autochthonous } \\
\text { or } \\
\text { parautochthonous }\end{array}$ & $57.6^{*}$ & 73.8 \\
\hline LACM 148311 & Fernando Fm. & $\begin{array}{l}\text { Pliocene- } \\
\text { Pleistocene }\end{array}$ & Autochthonous & - & - \\
\hline LACM 148312 & Fernando Fm. & $\begin{array}{l}\text { Pliocene- } \\
\text { Pleistocene }\end{array}$ & Autochthonous & $57.1^{*}$ & - \\
\hline LACM 156334 & $\begin{array}{l}\text { San Diego } \\
\text { Fm. }\end{array}$ & Pliocene & Autochthonous & 67.5 & - \\
\hline LACM 159028 & $\begin{array}{l}\text { Palos Verdes } \\
\text { Ss. }\end{array}$ & Pleistocene & Poor provenance & 101.5 & 97.1 \\
\hline $\begin{array}{l}\text { SDNHM } \\
23056\end{array}$ & $\begin{array}{l}\text { San Mateo } \\
\text { Fm. }\end{array}$ & $\begin{array}{l}\text { Zanclean, } \\
5.33-4.6 \\
\mathrm{Ma}\end{array}$ & $\begin{array}{l}\text { Autochthonous } \\
\text { or } \\
\text { parautochthonous }\end{array}$ & - & - \\
\hline $\begin{array}{l}\text { SDNHM } \\
23959\end{array}$ & $\begin{array}{l}\text { San Mateo } \\
\text { Fm. }\end{array}$ & $\begin{array}{l}\text { Zanclean, } \\
5.33-4.6 \\
\mathrm{Ma}\end{array}$ & $\begin{array}{l}\text { Autochthonous } \\
\text { or } \\
\text { parautochthonous }\end{array}$ & 90.07 & 82.6 \\
\hline $\begin{array}{l}\text { SDNHM } \\
24448\end{array}$ & $\begin{array}{l}\text { San Mateo } \\
\text { Fm. }\end{array}$ & $\begin{array}{l}\text { Zanclean, } \\
5.33-4.6 \\
\mathrm{Ma}\end{array}$ & $\begin{array}{l}\text { Autochthonous } \\
\text { or } \\
\text { parautochthonous }\end{array}$ & $77.39 *$ & 74.1 \\
\hline $\begin{array}{l}\text { SDNHM } \\
29742\end{array}$ & $\begin{array}{l}\text { San Diego } \\
\text { Fm. }\end{array}$ & $\begin{array}{l}\text { Zanclean, } \\
\sim 4.2 \mathrm{Ma}\end{array}$ & $\begin{array}{l}\text { Autochthonous } \\
\text { or } \\
\text { parautochthonous }\end{array}$ & $86.71^{*}$ & 96.89 \\
\hline $\begin{array}{l}\text { SDNHM } \\
53167\end{array}$ & $\begin{array}{l}\text { Capistrano } \\
\text { Fm. }\end{array}$ & $\begin{array}{l}\text { Messinian- } \\
\text { Zanclean, } \\
\text { 5.6-3.7 Ma }\end{array}$ & Autochthonous & 103.86 & 89.83 \\
\hline SDNHM & Niguel Fm. & Pliocene & Allochthonous & - & - \\
\hline
\end{tabular}




\begin{tabular}{|l|l|l|l|l|l|}
\hline 73462 & & & & \\
\hline $\begin{array}{l}\text { SDNHM } \\
77343\end{array}$ & San Mateo & $\begin{array}{l}\text { Zanclean, } \\
5.33-4.6 \\
\text { Ma }\end{array}$ & $\begin{array}{l}\text { Autochthonous } \\
\text { or } \\
\text { parautochthonous }\end{array}$ & - & - \\
\hline $\begin{array}{l}\text { SDNHM } \\
77430\end{array}$ & San Mateo & $\begin{array}{l}\text { Zanclean, } \\
5.33-4.6\end{array}$ & $\begin{array}{l}\text { Autochthonous } \\
\text { or } \\
\text { parautochthonous }\end{array}$ & 27.53 & \\
\hline UCMP 219502 & Purisima Fm. & $\begin{array}{l}\text { Messinian, } \\
6.9-5.33 \\
\text { Ma }\end{array}$ & $\begin{array}{l}\text { Autochthonous } \\
\text { or } \\
\text { parautochthonous }\end{array}$ & $114.1^{*}$ & 112.2 \\
& & & & \\
& & & \\
\hline
\end{tabular}




\section{Table 2 (on next page)}

Summary of corrected ages of Otodus megalodon occurrences used in the Optimal Linear Estimation analysis. 
1 Table 2. Summary of corrected ages of Otodus megalodon occurrences used in the Optimal

2 Linear Estimation analysis.

3

\begin{tabular}{|c|c|c|c|c|}
\hline Locality & Formation & Country & $\begin{array}{l}\text { Age (Pimiento } \\
\text { \& Clements) }\end{array}$ & Corrected Age \\
\hline $\begin{array}{l}\text { Kingsford } \\
\text { Mine }\end{array}$ & $\begin{array}{l}\text { Bone Valley } \\
\text { Fm. }\end{array}$ & $\overline{\text { USA }}$ & $10.3-4.9 \mathrm{Ma}$ & $10.3-4.9 \mathrm{Ma}$ \\
\hline $\begin{array}{l}\text { Payne Creek } \\
\text { Mine }\end{array}$ & $\begin{array}{l}\text { Bone Valley } \\
\text { Fm. }\end{array}$ & USA & $5.3-3.6 \mathrm{Ma}$ & $10.3-4.9 \mathrm{Ma}$ \\
\hline $\begin{array}{l}\text { Four Corners } \\
\text { Mine }\end{array}$ & $\begin{array}{l}\text { Bone Valley } \\
\text { Fm. }\end{array}$ & USA & $5.3-3.6 \mathrm{Ma}$ & $5.8-4.9 \mathrm{Ma}$ \\
\hline $\begin{array}{l}\text { East Coast } \\
\text { Aggregates }\end{array}$ & $\begin{array}{l}\text { Tamiami } \\
\text { Formation }\end{array}$ & USA & $5.3-3.6 \mathrm{Ma}$ & $4.2-3.9$ \\
\hline $\begin{array}{l}\text { Lee Creek } \\
\text { Mine }\end{array}$ & $\begin{array}{l}\text { Yorktown } \\
\text { Formation }\end{array}$ & USA & $5.3-3.6 \mathrm{Ma}$ & $4.9-3.92$ \\
\hline $\begin{array}{l}\text { Elsmere } \\
\text { Canyon }\end{array}$ & $\begin{array}{l}\text { Towsley } \\
\text { Formation }\end{array}$ & USA & $5.3-3.6 \mathrm{Ma}$ & $10.0-5.3 \mathrm{Ma}$ \\
\hline $\begin{array}{l}\text { Lawrence } \\
\text { Canyon }\end{array}$ & $\begin{array}{l}\text { San Mateo } \\
\text { Formation }\end{array}$ & USA & $10.3-4.9 \mathrm{Ma}$ & $5.33-4.6$ \\
\hline $\begin{array}{l}\text { San Juan } \\
\text { Capistrano }\end{array}$ & $\begin{array}{l}\text { Capistrano } \\
\text { Formation }\end{array}$ & USA & $11.6-3.6 \mathrm{Ma}$ & $5.6-3.7 \mathrm{Ma}$ \\
\hline Santa Cruz & $\begin{array}{l}\text { Purisima } \\
\text { Formation }\end{array}$ & USA & N/A & $6.9-5.33$ \\
\hline La Joya & $\begin{array}{l}\text { San Diego } \\
\text { Formation }\end{array}$ & USA & $3.6-2.6 \mathrm{Ma}$ & $4.2-3.6 \mathrm{Ma}$ \\
\hline Garnet Canyon & $\begin{array}{l}\text { Imperial } \\
\text { Formation }\end{array}$ & USA & N/A & $6.43-4.187 \mathrm{Ma}$ \\
\hline Bolinas & $\begin{array}{l}\text { Santa Cruz } \\
\text { Mudstone }\end{array}$ & USA & $5.3-2.6 \mathrm{Ma}$ & 7.6-6.5 Ma \\
\hline Kambul & $\begin{array}{l}\text { Carrillo Puerto } \\
\text { Formation }\end{array}$ & Mexico & $\mathrm{N} / \mathrm{A}$ & $10.3-4.6 \mathrm{Ma}$ \\
\hline Corkscrew Hill & $\begin{array}{l}\text { Tiburazon } \\
\text { Formation }\end{array}$ & Mexico & $5.3-2.6 \mathrm{Ma}$ & $6.76-3.6 \mathrm{Ma}$ \\
\hline Casa el Jebe & $\begin{array}{l}\text { Codore } \\
\text { Formation }\end{array}$ & Venezuela & $\mathrm{N} / \mathrm{A}$ & $5.33-3.6$ \\
\hline El Yacural & $\begin{array}{l}\text { Paraguana } \\
\text { Formation }\end{array}$ & Venezuela & $5.33-3.6 \mathrm{Ma}$ & $5.33-3.6 \mathrm{Ma}$ \\
\hline Punta la Gorda & $\begin{array}{l}\text { Onzole/Borbon } \\
\text { Formation }\end{array}$ & Ecuador & $5.33-2.6 \mathrm{Ma}$ & $5.33-3.4 \mathrm{Ma}$ \\
\hline $\begin{array}{l}\text { Punta la } \\
\text { Colorada }\end{array}$ & $\begin{array}{l}\text { Onzole/Borbon } \\
\text { Formation }\end{array}$ & Ecuador & $5.33-2.6 \mathrm{Ma}$ & 5.33-3.4 Ma \\
\hline $\begin{array}{l}\text { Punta } \\
\text { Mansueto }\end{array}$ & $\begin{array}{l}\text { Chagres } \\
\text { Formation }\end{array}$ & Panama & N/A & $8.29-5.12$ \\
\hline Sunlands & Loxton Sands & Australia & $4.3-3.4 \mathrm{Ma}$ & $7.2-3.4 \mathrm{Ma}$ \\
\hline
\end{tabular}




\begin{tabular}{|c|c|c|c|c|}
\hline $\begin{array}{l}\text { Pumping } \\
\text { Station }\end{array}$ & & & & \\
\hline Dutton Way & $\begin{array}{l}\text { Whaler's Bluff } \\
\text { Formation }\end{array}$ & Australia & $5.3-3.6 \mathrm{Ma}$ & $5.33-3.6 \mathrm{Ma}$ \\
\hline Beaumaris & $\begin{array}{l}\text { Black Rock } \\
\text { Sand }\end{array}$ & Australia & $5.0-3.4 \mathrm{Ma}$ & $6.0-4.9 \mathrm{Ma}$ \\
\hline $\begin{array}{l}\text { Fossil Rock } \\
\text { Stack }\end{array}$ & $\begin{array}{l}\text { Grange Burn } \\
\text { Formation }\end{array}$ & Australia & $5.0-4.0 \mathrm{Ma}$ & $5.4-3.5 \mathrm{Ma}$ \\
\hline Pipiriki & $\begin{array}{l}\text { Matemateaonga } \\
\text { Formation }\end{array}$ & $\begin{array}{l}\text { New } \\
\text { Zealand }\end{array}$ & $4.8-3.6 \mathrm{Ma}$ & $5.5-4.7 \mathrm{Ma}$ \\
\hline Patutahi Quarry & $\begin{array}{l}\text { Tokomaru } \\
\text { Formation }\end{array}$ & $\begin{array}{l}\text { New } \\
\text { Zealand }\end{array}$ & $\mathrm{N} / \mathrm{A}$ & 7.2-3.7 Ma \\
\hline $\begin{array}{l}\text { Bonares-Case } \\
\text { del Pin }\end{array}$ & $\begin{array}{l}\text { Arenas de } \\
\text { Huelva } \\
\text { Formation }\end{array}$ & Spain & $5.33-3.6 \mathrm{Ma}$ & $5.33-3.6 \mathrm{Ma}$ \\
\hline Can Picafort & $\begin{array}{l}\text { Son Mir } \\
\text { Sequence }\end{array}$ & Spain & $5.3-2.6 \mathrm{Ma}$ & $5.33-3.6 \mathrm{Ma}$ \\
\hline Vale de Zebro & $\begin{array}{l}\text { Esbarrondadoiro } \\
\text { Formation }\end{array}$ & Portugal & $\mathrm{N} / \mathrm{A}$ & $8.58-4.37 \mathrm{Ma}$ \\
\hline $\begin{array}{l}\text { Santa } \\
\text { Margarida }\end{array}$ & $\begin{array}{l}\text { Esbarrondadoiro } \\
\text { Formation }\end{array}$ & Portugal & $\mathrm{N} / \mathrm{A}$ & $8.58-4.37 \mathrm{Ma}$ \\
\hline $\begin{array}{l}\text { Continental } \\
\text { shelf }\end{array}$ & Unknown & Portugal & $\mathrm{N} / \mathrm{A}$ & 6.1-4.4 Ma \\
\hline Cre outcrop & Touril Complex & Portugal & $5.3-3.6 \mathrm{Ma}$ & $5.33-3.6 \mathrm{Ma}$ \\
\hline Castell'Arquato & Unknown & Italy & $5.3-2.6 \mathrm{Ma}$ & $5.33-4.0 \mathrm{Ma}$ \\
\hline Miano & Unknown & Italy & $5.3-2.6 \mathrm{Ma}$ & $5.33-4.0 \mathrm{Ma}$ \\
\hline Colli Piacentini & Unknown & Italy & $5.3-2.6 \mathrm{Ma}$ & $5.33-4.0 \mathrm{Ma}$ \\
\hline Maiatico & Unknown & Italy & $5.3-2.6 \mathrm{Ma}$ & $5.33-4.0 \mathrm{Ma}$ \\
\hline $\begin{array}{l}\text { Tra Lorenzana } \\
\text { e Lari }\end{array}$ & Unknown & Italy & 5.3-2.6 Ma & $5.33-4.0 \mathrm{Ma}$ \\
\hline Pienza & Unknown & Italy & $5.3-2.6 \mathrm{Ma}$ & $5.33-4.0 \mathrm{Ma}$ \\
\hline Siena & Unknown & Italy & $5.3-2.6 \mathrm{Ma}$ & $5.33-4.0 \mathrm{Ma}$ \\
\hline Colline Pisane & Unknown & Italy & $5.3-2.6 \mathrm{Ma}$ & $5.33-4.0 \mathrm{Ma}$ \\
\hline Boso Peninsula & $\begin{array}{l}\text { Senhata } \\
\text { Formation }\end{array}$ & Japan & $\mathrm{N} / \mathrm{A}$ & $6.3-5.12 \mathrm{Ma}$ \\
\hline $\begin{array}{l}\text { Kita-Daito- } \\
\text { Jima }\end{array}$ & $\begin{array}{l}\text { Daito } \\
\text { Limestone }\end{array}$ & Japan & 3.6-0.8 Ma & 4.7-3.3 Ma \\
\hline Choshi & $\begin{array}{l}\text { Na-Arai } \\
\text { Formation }\end{array}$ & Japan & $\mathrm{N} / \mathrm{A}$ & $5.33-4.36 \mathrm{Ma}$ \\
\hline $\begin{array}{l}\text { Sendai-Iwate } \\
\text { area }\end{array}$ & $\begin{array}{l}\text { Tatsunokuchi } \\
\text { Formation }\end{array}$ & Japan & N/A & 5.6-3.9 Ma \\
\hline
\end{tabular}

